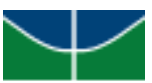

UnB

Universidade de Brasília

Instituto de Letras

Departamento de Teoria Literária e Literaturas

Programa de Pós-Graduação em Literatura
\end{abstract}

\author{
Daniel Barbosa Cardoso
}

\title{
A questão do sentido na ficcão de Maurice Blanchot
}


Universidade de Brasília

Instituto de Letras

Departamento de Teoria Literária e Literaturas

Programa de Pós-Graduação em Literatura

\section{Daniel Barbosa Cardoso}

\section{A questão do sentido na ficcão de Maurice Blanchot}

Tese apresentada ao curso de Doutorado em Literatura do Departamento de Teoria Literária e Literaturas da Universidade de Brasília, como parte dos requisitos para obtenção do grau de Doutor, elaborada sob orientação do Professor Dr. Piero Luis Zanetti Eyben. 



\section{DANIEL BARBOSA CARDOSO}

\section{A QUESTÃO DO SENTIDO NA FICÇÃO DE MAURICE BLANCHOT.}

Tese apresentada ao curso de Doutorado em Literatura do Departamento de Teoria Literária e Literaturas da Universidade de Brasília, aprovada pela banca examinadora.

Brasília, 17 de dezembro de 2014.

Dr. Piero Luis Zanetti Eyben

Universidade de Brasília — Presidente

Dr. Alberto Pucheu Neto

Universidade Federal do Rio de Janeiro — Membro Externo

Dr. Eclair Antonio Almeida Filho

Universidade de Brasília - Membro Externo

Dra. Maria da Glória Magalhães dos Reis

Universidade de Brasília - Membro Interno

Dr. Wilton Barroso Filho

Universidade de Brasília - Membro Interno

Dra. Fabricia Walace Rodrigues

Universidade de Brasília - Suplente 


\section{AGRADECIMENTOS}

A meus pais e avós, que na incerteza cósmica das genealogias algo me ensinaram. 
écrire -

L'encrier, cristal comme une conscience, avec sa goutte, au fond, de ténèbres relative à ce que quelque chose soit : puis, écarte la lampe.

Tu remarquas, on n'écrit pas, lumineusement, sur champ obscur, L'alphabet des astres, seul, ainsi s'indique, ébauché ou interrompu ; I'homme poursuit noir sur blanc. ${ }^{1}$

(MALLARMÉ)

${ }^{1}$ escrever -

O tinteiro, cristal como uma consciência, com sua gota, no fundo, de trevas relativa a que alguma coisa seja: então, afasta a lâmpada.

Você notou, não se escreve, luminosamente, sobre campo obscuro, O alfabeto dos astros, só, assim se indica, esboçado ou interrompido; o homem persegue negro sobre branco. 


\section{Resumo}

O presente trabalho foi formulado, em grande parte, em estudos e publicações cuja característica principal é derivarem do trabalho do grupo Escritura: Linguagem e Pensamento, cujos trabalhos são conduzidos no Departamento de Teoria Literária e Literaturas da Universidade de Brasília pelo Professor Piero Eyben, que também é o orientador da tese. O que há de comum entre todos é o fato de lidarem com o pensamento e a literatura de Maurice Blanchot levando em conta a questão do sentido e da linguagem e suas ressonâncias filosóficas. Necessário também dizer que o presente trabalho opera em continuidade com nossa dissertação de Mestrado, produzida no Departamento de Filosofia da Universidade de Brasília, que se limitava à ensaística de Maurice Blanchot; opera-se, aqui, tentativa similar, dessa vez buscando os textos do autor que se inscrevem no registro incerto da ficção.

Palavras-chave: Maurice Blanchot; Fenomenologia; Sentido; Literatura; Filosofia. 


\begin{abstract}
The present work is comprised, in great measure, by essays and publications that resulted from my engagement in the research group Writing: Language and Thought, whose activities are linked to the Department of Literary Theory and Literatures at the University of Brasilia, under the leadership of Professor Piero Eyben - who is also the supervisor of this thesis. Common to them all is the fact that they tread upon the thinking and literary texts of Maurice Blanchot, paying particular attention to the questions of meaning and language and their philosophical implications. Imperative is also to stress that the work presented here is a further development of my Master's dissertation, a research project that was undertaken in the Department of Philosophy of the same University, which was circumscribed to the essayistic work of Blanchot. The present thesis entertains a similar aspiration, this time focusing on the author's texts that belong to the ambivalent domain of fiction.
\end{abstract}

Palavras-chave: Maurice Blanchot; Phenomenology; Sense; Literature; Philosophy. 


\section{Resumé}

Le travail suivant a été formulé pour sa plupart dans des études et publications dont la majeure characteristique est d'être derivés du travail du group de recherches Écriture: Langage et Pensée, conduit au Département de Théorie Littéraire et Littératures de L'Université de Brasilia par le Professeur Piero Eyben, qui est aussi le superviseur de la thèse présente. Ce qu'il y a de commun entre tous c'est le fait que tous lident avec la pensée et la littérature de Maurice Blanchot, tenant en compte la question du sens e du langage e ses réssonances philosophies. II faut dire aussi que le présent travail opère en continuité avec ma dissertation de Maîtrise, produite dans le Département de Philosophie de la même Université, qui était limitée à les essais critiques de Blanchot; On fait ici la même tentative, cette fois en quête des textes de l'auteur qui sont inscrits dans le registre uncertain de la fiction.

Palavras-chave: Maurice Blanchot; Phénoménologie; Sens; Littérature; Philosophie. 


\section{Sumário}

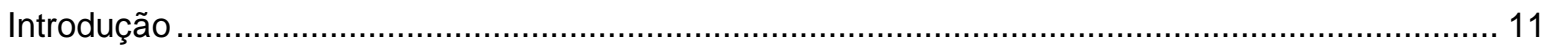

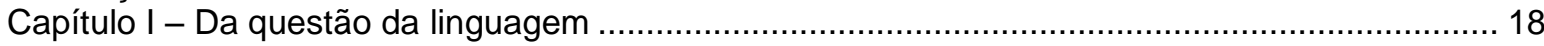

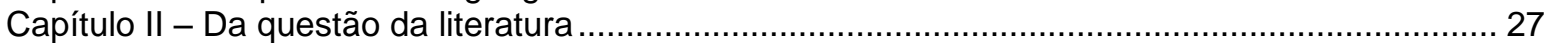

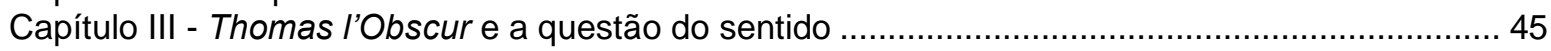

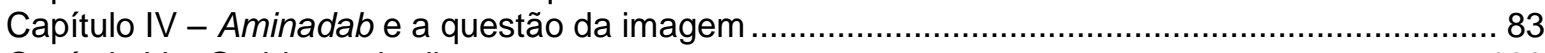

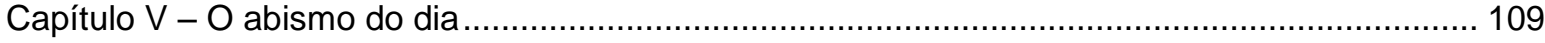

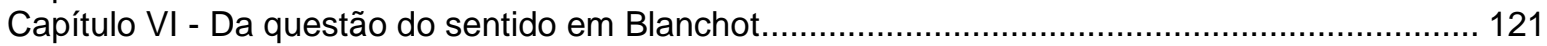

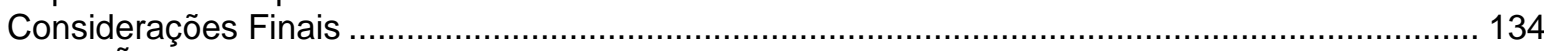

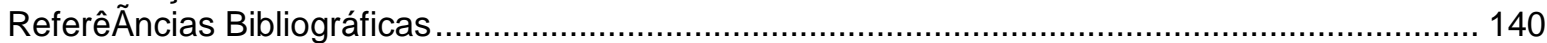


Introdução 
"À travers les mots passait encore un peu de jour." 2

O presente trabalho busca investigar, da maneira mais ampla possível, a questão do sentido na literatura, através da análise pontual de alguns momentos exemplares em que foi colocada, e em especial a questão do sentido como foi colocada por certa fenomenologia, em especial a elaborada nos primórdios da obra de Heidegger, com a questão do sentido colocada pela filosofia e pela literatura contemporânea francesa, presente nas obras de Jacques Derrida, Maurice Blanchot, e Jean-Luc Nancy, além da fortuna crítica que se ergueu em torno de seus pensamentos. Não é nosso propósito uma grande introdução, mas deter-nos nos textos, em problemas e dispositivos que serão analisados pontualmente ao longo dos capítulos. Basta dizer que partilhamos com Nancy a posição filosófica, elaborada ao longo de toda sua obra, e especialmente nos recentes La déclosion e L'adoration, de que o sentido é a questão incandescente do ocidente, e mesmo o que em certa medida o define: e que esse sentido, que o sentido desse sentido não se limita a testemunhar a fenomenalidade do fenômeno, a visibilidade do visível ou a verdade da teoria, mas as linhas de fuga que preconizam o acontecimento desses extratos da escritura, o assombramento do testemunho pela possibilidade assombrosa do perjúrio, pela possibilidade de ficção, como dizia Derrida, e que a questão ou o privilégio dado à questão na ontologia é prova algo concreta da verdade desse axioma: o sentido é a desconstrução do sentido, ou no sentido acontece a desconstrução do sentido (o que é dizer totalmente outra que dizer que não há sentido na linguagem, nas coisas, na vida ou na literatura). A tentativa do presente texto, para além de um mero catálogo das formas que a questão do sentido, da linguagem, e da literatura tomaram ao longo do pensamento e da filosofia contemporâneas - no que todas essas unidades aqui tem valor limitado ou limítrofe - é demonstrar que aparato filosófico e semântico, que formas literárias ou ficcionais adquire essa questão do sentido, em alguns textos ficcionais singulares de Blanchot.

Da questão do sentido, da linguagem, e de seu papel fundamental na crítica à fenomenologia elaborada por Heidegger, em especial no que tange o conceito de intuição categorial e toda sua implicação na ontologia em sentido geral como na

\footnotetext{
2 "Através das palavras passava ainda um pouco da luz do dia." (BLANCHOT, 1962, p. 17). Todas as traduções, inclusive a anterior, são de minha autoria, mesmo quando tratar-se de textos já traduzidos para o português, em respeito às idiossincrasias do texto de Maurice Blanchot.
} 
ontologia da literatura, de modo singular, mas também das múltiplas configurações que a questão do sentido e da linguagem adquire na gama mais vasta o possível de pensadores, escritores, filósofos, e em especial nas obras ficcionais de Blanchot; além disso, as questões adjacentes, a questão da poesia, da literatura, da morte, do testemunho, da linguagem e do sentido, nas obras de Blanchot e de pensamentos semelhantes ao seu; por fim, que instrumentos são usados nessa linguagem literário-filosófica que não fala a partir de um fora inexorável da linguagem, que configurações adquire o instrumental teórico e filosófico nesses textos exemplares. Essas são as questões de que aqui pretendemos tratar.

Daremos atenção especial aos textos ficcionais de Blanchot, como foi dito, na medida da possibilidade de análise dos mesmos. Primeiramente Thomas l'obscur, romance de 1941 que seria recortado radicalmente e relançado sob a alcunha "récit" em 1950, livro primeiro e talvez a narrativa quintessencial de sua obra, ao qual daremos especial atenção à versão condensada, mais recente; Aminadab, segundo livro de Blanchot, de 1943, e que também se inscreve no registro do romance; e, por fim, La folie du jour, texto publicado na revista L'Empédocle com o título "Un Récit" em 1949 e reeditado em 1973 sob o título mencionado, cujos artifícios textuais foram motivo de alguns dos seminários de Derrida ministrados na década de 1970, de suma importância para as questões de que queremos tratar na presente tese. Os três estão entre os textos ficcionais mais densos de Maurice Blanchot, sendo ricos nos motivos e questões pelas quais sua obra ficou conhecida e tornou-se muito influente na filosofia e literatura francesas do século $X X$, em especial para as filosofias que privilegiam a literatura enquanto "objeto" ou "fenômeno", as únicas que aqui nos interessam. ${ }^{3}$ Daremos especial atenção, igualmente, ao ensinamento de Derrida em torno desses textos, em especial o material publicado no livro Parages sur Maurice Blanchot, e de que modo se relacionam a certa concepção da literatura, da filosofia, da escritura e do fenômeno do sentido em geral que neles é articulada. Ademais será dada atenção semelhante às outras figuras linguísticas e de estilo de

\footnotetext{
${ }^{3}$ Se se pode tratar de modo analítico da importância do contexto na escritura de um artefato textual como uma tese de Doutorado, e aqui partimos desse princípio, vale citar a importância de um dos colóquios em que as questões aqui tratadas se pronunciaram fortemente, a dizer, o Seminário Pensamento Intruso: Literatura, Filosofia e Infinito, realizado pelo grupo de estudos Escritura: Linguagem e Pensamento no mês de Setembro de 2013, na Universidade de Brasília, em que todas essas questões foram fartamente discutidas. Vale mencionar também a importância do trabalho realizado pelo Professor Dr. Piero Eyben, líder do grupo de estudos, e se possível dar outro testemunho do alcance desse trabalho.
} 
que Blanchot parte para efetuar o que seria a sua concepção da literatura e de que modo essa se relaciona com a filosofia.

Se o que caracteriza a tese e o posicionamento que lhe é intrínseco são aqui nossa obrigação, gostaríamos de atestar a singularidade desses textos de Blanchot em uma série de questões pertinentes a sua obra, e que vários desses elementos se condensam para dar origem a um texto que é intrinsecamente uma pletora de temas, em que se encontram diversas das questões de Blanchot, em especial a do sentido. É o mapeamento do modo como essa questão se distribui em sua obra o vetor dos tópicos de que aqui pretendemos tratar. Partiremos de uma exposição da questão do sentido na obra de Heidegger e na fenomenologia em sentido amplo - e outra tese presente aqui é a de que Heidegger é central para certa concepção francesa da literatura, mesmo para certa concepção do que é a fenomenologia e a filosofia classificadas algo lacônica e ironicamente "continentais", fato de que nosso primeiro capítulo busca dar testemunho, para depois tratar da questão da literatura na obra de Blanchot, construída ao longo de seus ensaios ditos "críticos", voltados em certa medida para a análise de obras de terceiros, objeto do segundo capítulo; os demais capítulos dão conta dos textos mencionados de Blanchot, por ordem de publicação: Thomas l'obscur, Aminadab e La folie du jour, e sua relação com a questão do sentido, da desconstrução, e de certa filosofia que floresce em torno das obras de Jacques Derrida, Jean-Luc Nancy, Philippe Lacoue-Labarthe, entre diversos outros críticos, poetas e filósofos de que o volume da Revue Critique editado em 1966 em homenagem a Blanchot - entre eles Jean Starobinski, Georges Poulet, René Char, Michel Foucault - ajuda a evidenciar. Buscaremos as passagens fulcrais desses textos em que se exemplifica de forma mais intensa a busca de Blanchot pelo que ele próprio chamou de "espaço literário", quais são as imagens e dispositivos privilegiados por Blanchot, que estruturas neles se desenvolvem, e de que modo se relacionam a certa história e concepção da literatura e da filosofia - e da relação entre as duas.

Dessa visão da literatura podemos resumir, partindo de certas palavras de Jacques Derrida e de Michel Foucault, em uma aproximação algo insólita, muito embora essa preocupação com a questão da literatura e certo posicionamento dela no quadro geral do pensamento tenha aproximado esses dois pensadores, aluno e professor, durante algum tempo: trata-se da questão da ontologia das formas 
literárias. Citamos Derrida, em Demeure, onde essas questões são tratadas longamente:

(...) There is no essence or substance of literature: literature is not. It does not exist. It does not remain at home, abidingly [à demeure] in the identity of a nature or even of a historical being identical with itself. It does not maintain itself abidingly [à demeure], at least if "abode [demeure]" designates the essential stability of a place; it only remains [demeure] where and if "to be abidingly [être à demeure]" in some "abiding order [mise en demeure]" means something else. The historicity of its experience - for there is one - rests on the very thing no ontology could essentialize. No exposition, no discursive form is intrinsically or essentially literary before and outside of the function it is assigned or recognized by a right, that is, a specific intentionality inscribed directly on the social body. (DERRIDA, 1998, p. 28)

Depreende-se dessas linhas uma constante no pensamento de Derrida, de Blanchot, de Foucault e de quantos tenham pensado a literatura no século XX francês: a da impossibilidade de uma ontologia do "objeto" literário - e a talvez consequente impossibilidade de uma ontologia geral do sentido. Para Derrida a literatura é justamente o que só reside, só é, só chega a esboçar uma existência nessas áreas limítrofes, fronteiriças, de que a própria e necessária tradução do termo latino literatura é evidência, com sua história tortuosa, revolucionária etc. A literatura - assim como o testemunho - nunca tem seu status garantido, fixado de uma vez por todas; é, em certo sentido, um outro "indecidível" de Derrida, essas estruturas bífidas, em "duplo elo" (double bind) que ele descreveu em toda sua obra. É a literatura, em seu ser precário, "escarpado", dizia Foucault, que mostra à ontologia novas formas e configurações. Derrida, inspirado em Blanchot, vai se interessar por todos os protocolos, signos, assinaturas, tudo isso que uma longa e compreensível tradição marca como "paratexto", como na obra de Gérard Genette, tudo isso que funciona aquém - ou além - do que essa tradição definiu como oposto ao lado supostamente genuíno, de dentro da obra literária, todos esses artifícios que estabelecem, enfim, os limites entre o que é e o que não é literatura. A literatura é assim multiplicada, nas obras de Blanchot e de Derrida, ao infinito. Cada um de seus códigos, protocolos, mínimos gestos é motivo de reflexões sobre a ontologia do literário e sobre a ontologia em sentido geral.

Posição semelhante quanto ao ser da literatura encontramos em Foucault, especialmente nos textos de antes de Les mots et les choses sobre a literatura, e assuntos afins, reunidos nos Dits et Écrits. Ali se pode encontrar um trecho como o 
seguinte, a respeito, novamente, da impossibilidade e da possibilidade de uma ontologia da literatura:

\begin{abstract}
Je me demande si on ne pourrait pas faire, ou du moins esquisser à distance, une ontologie de la littérature à partir de ces phénomènes d'autoreprésentation du langage; de telles figures, qui sont en apparence de l'ordre de la ruse ou de l'amusement, cachent, c'est-à-dire trahissent, le rapport que le langage entretient avec la mort - avec cette limite à laquelle il s'adresse et contre laquelle il est dressé. II faudrait commencer par une analytique générale de toutes les formes de reduplication du langage dont on peut trouver des exemples dans la littérature occidentale. Ces formes à n'en pas douter sont en nombre fini, et on doit pouvoir en dresser le tableau universel. Leur extrême discrétion souvent, le fait qu'elles sont parfois cachées et jetées là comme par hasard ou inadvertance ne doivent pas faire illusion: ou plutôt il faut reconnaître en elles le pouvoir même de l'illusion, la possibilité pour le langage (chaîne monocorde) de se tenir debout comme une oeuvre. La reduplication du langage, même si elle est secrète, est constitutive de son être en tant qu'oeuvre, et les signes qui peuvent en apparaître, il faut les lire comme des indications ontologiques. (FOUCAULT, 2001, p. 253) ${ }^{4}$
\end{abstract}

O que em Foucault era ainda a possibilidade de uma construção, tomando por base os momentos em que a literatura supostamente se mostra a si mesma, ou dá testemunho de si mesma, em Blanchot (e posteriormente em Derrida) será o désoeuvrement completo da obra, isto é, dar-se-á ênfase aos momentos em que a literatura se mostra, e se mostra no "desfazimento" que é sua herança e ontologia. Há, talvez, semelhança quanto ao motivo: tanto Foucault como Derrida lançam mão da estrutura "meta-literária", auto-referencial, da mise en abyme, quando relacionam a literatura à morte e ao sentido: mas essa mesma mise en abyme, em Derrida, é uma estrutura que se repete em toda a linguagem, extrapolando, talvez, a hipótese que Foucault aventava em "Da linguagem ao infinito", um dos ensaios reunidos no volume dos Dits et Écrits dedicado à literatura. Isto é, essa reduplicação não atinge somente os momentos de autorrepresentação da obra - a mise en abyme - mas também nos títulos, nos inícios, epígrafes, prefácios, fins dos textos, mas marcas de

\footnotetext{
4 "Pergunto-me se não seria possível fazer, ou pelo menos esboçar, a distância, uma ontologia da literatura a partir desses fenômenos de auto-representação da linguagem: tais figuras, que são aparentemente da ordem do artifício ou da diversão, escondem, ou melhor, traem a relação que a linguagem mantém com a morte - com esse limite para o qual ela se dirige e contra o qual ela é construída. Seria preciso começar por uma analítica geral de todas as formas de reduplicação da linguagem das quais se podem encontrar exemplos na literatura ocidental. Essas formas, sem dúvida alguma, são em número finito, e delas se deve poder construir o quadro universal. Frequentemente, sua extrema discrição, o fato de que elas são às vezes escondidas e lançadas aí como por acaso ou inadvertência não devem provocar ilusão: ou melhor, é preciso reconhecer nelas o próprio poder da ilusão, a possibilidade para a linguagem (cadeia monocórdia) de se manter de pé como uma obra. A reduplicação da linguagem, mesmo quando ela é secreta, é constitutiva do seu ser como obra, e os signos que nela podem aparecer, é preciso lê-los como indicações ontológicas." (FOUCAULT, 2001, p. 50)
} 
gênero, enfim, em todos esses sítios dados como desimportantes (e por isso, talvez, tão centrais) do que se convencionou chamar "literatura".

É no contexto dessas discussões que buscaremos realizar o presente trabalho. A obra de Blanchot se situa no limiar, por assim dizer, de todas essas questões. Situa-se, forçosamente, no limiar entre a filosofia, a literatura, e a crítica, limiar que buscaremos descrever à medida de nossas capacidades. Também em toda a obra de Blanchot são patentes esses aspectos, e buscaremos analisar o que ela traz de particular ao debate quanto a relação entre filosofia e literatura. Partiremos também do princípio de que toda literatura se constrói à medida das necessidades que traz o pensamento, não somente em sentido unilateral, mas de influência mútua, bífida, por assim dizer. Se a filosofia ou ao menos certa preocupação filosófica se faz presente na obra de Blanchot, deverá também sê-lo no presente texto, talvez sob pena de ocupar um espaço mais afeito à teoria e crítica literárias. Justificamos essa presença sob a égide da própria obra de Blanchot, que chamou ao menos uma vez a filosofia de "notre compagne clandestine", depositária de nossos segredos e reflexões mais intensas quanto ao ser do objeto literário. A bibliografia, crescente porém ainda mínima, no que diz respeito ao estudo da obra ficcional de Blanchot, certamente se fará também demonstrar ao longo das próprias linhas. Foram filósofos os que no mais das vezes se deixaram arrebatar por suas ficções, e essa presença certamente se fará notar no presente ensaio.

Por óbvio, não supomos, com o presente trabalho, o erigir de uma ontologia, ainda que outra, da literatura. Tampouco supomos possível, é importante assinalálo, que qualquer análise estrutural pode simplesmente furtar-se à questão da ontologia da literatura. 
Capítulo I - Da questão da linguagem 
Desde o princípio, o problema da fenomenologia é o da constituição, da gênese do sentido das coisas da experiência. A fenomenologia de matriz husserliana, primeira, definida em alguns artigos e livros nos primeiros anos do século XX, se ocupa de diversas tarefas metodológicas, mas uma delas se destaca sobremaneira: para o fenomenólogo, a experiência da consciência - que é a experiência exemplar da intencionalidade - é sempre um "direcionar-se a", isto é, dá-se sempre de modo duplo, pois experimentamos, pensamos, idealizamos, mas quando o fazemos necessariamente velamos o fazer, não vemo-lo: essa sombra, esse adumbramento é um fato bruto para o fenomenólogo, e o privilégio da chamada "redução fenomenológica" busca suspender o funcionamento estruturalmente recorrente da dita "atitude natural", essa disposição sempre já iniciada - e o aspecto temporal aqui é primevo - em relação ao mundo circundante, para usar os termos de Husserl, para tratar de buscar e descrever de maneira supostamente imediata os atos intencionais da consciência, e assim descrever todo um domínio que teria permanecido encoberto pela própria estrutura intencional da subjetividade. Uma questão, enfim, de método. E é nesse método que Heidegger foi formado, e de certo modo, como veremos, essa questão o aproxima de Husserl sob diversos aspectos; mas é a crítica desse método que foi, também, um dos vetores principais de seu pensamento e trajetória intelectual, desde os primeiros cursos ministrados em Freiburg, até Sein und Zeit, e além. Tentaremos nos ater a essa questão primeira: de que modo a questão da linguagem irrompe no pensamento heideggeriano, no contexto de sua crítica à fenomenologia, debate que viria a influenciar intensamente a literatura e a filosofia francesas ao longo do século XX.

Sein und Zeit, deveríamos lembrar, se o próprio Heidegger não o fizesse, contém uma aporia muito evidente: toda a descrição do ser do Dasein, que deveria proporcionar uma "detranscendentalização" da filosofia, um deixar de remeter à transcendência de um sentido anterior, enquanto ser-em, ser-com, ser-no-mundo, todas essas figuras acabam por dar ao Dasein um estatuto muito semelhante ao da consciência transcendental erigida como excesso último pela fenomenologia de Husserl, e todo esse excesso é epigrafado por uma aporia, contida em uma situação citada no diálogo O Sofista, de Platão, presente logo no início do livro: 
Visitante: "Então o esclareça para nós, que estamos confusos sobre isso. O que você quer significar quando diz ser? Obviamente você o sabe há muito tempo. Nós pensávamos sabê-lo, mas agora caímos em aporia."

Essa aporia indica, de modo muito fortuito, uma aporia maior, contida na estrutura do próprio livro, e que de certo modo acena para as possibilidades de seu não-encerramento (e, queremos crer, acena também para as estruturas de nãoencerramento do sentido que analisaremos nas narrativas de Maurice Blanchot). Buscaremos analisar esses aspectos de Sein und Zeit, mas consideramos que é necessário retornar às discussões que fundamentaram a noção de linguagem e do sentido na obra de Heidegger, que remontam a um conceito husserliano muito específico, delineado nas Investigações Lógicas, livro de 1900 que viria a inspirar gerações de fenomenólogos, Heidegger entre eles.

Ao passo que a fenomenologia husserliana buscava romper a camada cristalizada de sedimentações que impedem uma descrição precisa dos atos da consciência constituinte do mundo e da realidade, isto é, todos os atos mecânicos da "atitude natural" diante das coisas, de modo a permitir uma fenomenologia transcendental das formas categóricas da consciência e uma descrição final da constituição do sentido, para Heidegger essa tarefa não é somente infinita, como o era para Husserl, mas impossível. Retirando, ao acaso, uma frase de seu curso do inverno de 1923-1924, em que ainda ecoam incisivamente os ensinamentos de Husserl: "A linguagem fala não somente no curso da percepção, mas a guia; nós vemos através da linguagem..." ${ }^{n}$ Vemos que, se em Sein und Zeit aparentemente a linguagem fique em segundo plano na descrição fenomenológica do Dasein e do Inder-welt-sein - embora existam autores ${ }^{7}$ que sugerem precisamente o contrário -, para Heidegger a linguagem sempre foi um problema central. Os difíceis ensaios de uma destruição da ontologia que são publicados após Sein und Zeit, centrais para a concepção de literatura e de sentido que Blanchot viria a elaborar ao longo de sua obra ensaística e ficcional, foram precedidos de longas meditações sobre o logos apofântico entre os gregos e na fenomenologia de Husserl, de que buscaremos dar alguns detalhes a seguir.

\footnotetext{
${ }^{5}$ PLATÃO. O Sofista.

${ }^{6}$ HEIDEGGER, Martin. Introduction to Phenomenological Research, p. 22.

7 Pensamos especialmente nos ensaios de Cristina Lafont contidos em Heidegger, Language, and World-disclosure.
} 
Nas Investigações Lógicas, e na sexta investigação em especial, a única publicada no Brasil - e cabe mencionar que a importância desse texto, especificamente, para Heidegger diz muito sobre a decisão editorial - Husserl explora um conceito que Heidegger diria muito tempo mais tarde haver sido decisivo para os caminhos de seu pensamento, o conceito de intuição categorial. Para Husserl, há atos intencionais significantes que são completamente preenchidos por atos intuitivos "preenchedores", atos em que "a intenção de significação encontra, na simples percepção, o ato no qual ela se preenche de maneira completamente adequada"8. Esses atos são, talvez, os atos intencionais por excelência, que encontram na intuição e na percepção seus correspondentes perfeitos, e um preenchimento total da significação pela experiência. Mas há uma miríade de atos talvez a maioria dos atos significantes - aos quais não corresponde um preenchimento total, ou mesmo um preenchimento intuitivo mínimo, apenas protocolar, por assim dizer. Retornando às estruturas mínimas do juízo, atributivo e predicativo, Husserl utiliza o exemplo a seguir, uma sentença predicativa de tipo simples: "O ouro é amarelo", Gold ist gelb. Embora, quando pensamos nesse juízo, possamos ter uma noção do que seja o ouro, e uma noção do que seja o amarelo, o momento-amarelo do ouro, o é do juízo (a cópula) contém um excesso de significação, que não é preenchido intuitivamente na percepção. Esse excesso, quando tematizado, implica num retorno à proposição kantiana de que "o ser não é um predicado real". Cito Husserl:

O pensamento juízo se preenche na intuição interna de um juízo atual; mas nela não se preenche o pensamento do é. O ser não é nem um juízo, nem um componente real do juízo. Assim como o ser não é um componente real de um objeto externo, tampouco o é de um objeto interno; portanto, também não do juízo. No juízo - enunciado predicativo - o é figura como um momento da significação, tal como fazem também, por exemplo, ouro e amarelo, embora numa outra posição e função. O próprio é não figura aí; na palavra é, ele é apenas significado, ou seja, signifivamente visado. Entretanto, ele próprio é dado, ou pelo menos presumidamente dado, no preenchimento que em certas circunstâncias se amolda ao juízo, na tomada de consciência do estado de coisas presumido. Aparece agora não somente aquilo mesmo que é visado, na significação parcial ouro, e, analogamente, o amarelo, mas aparece também ouro-é-amarelo; o juízo e a intuição do juízo se unem aqui para constituir a unidade do juízo evidente e, no caso mais favorável, do juízo evidente, no sentido do limite ideal. ${ }^{9}$

\footnotetext{
${ }^{8}$ HUSSERL, Edmund. Investigações Lógicas, p. 100.

${ }^{9}$ Idem, p. 107.
} 
Os capítulos de que essas palavras foram recortadas viriam a influenciar de maneira decisiva o jovem Heidegger, que desde o início da década de 1910 trabalhava em seminários o então recente livro de Husserl, além de toda a tradição alemã e francesas formadas no contexto dessas discussões. Pois já encontra-se aí presente a ideia que retornaria a seus textos ao longo das décadas que seguiriam: a de que há um excesso de significação contido na própria estrutura do juízo, que não pode ser preenchido intuitivamente, nos moldes de um conceito sensível de intuição, somente podendo ser compreendido segundo um conceito categorial de intuição: pois, embora não seja possível uma confirmação intuitiva da cópula, há no entanto uma confirmação desse tipo. Há aqui uma aporia da doação ${ }^{10}$, se podemos dizê-lo, presente principalmente nos atos signitivos mais complexos, de que a cópula é o exemplo maior, mas que no fim das contas está presente em qualquer lugar em que um juízo se faça presente: pois, embora não percebamos o ser-ouro do ouro e o seramarelo do amarelo, compreendemos o que diz o ser entre o predicado ou atributo e o sujeito dos juízos apofânticos. Essa compreensão mediana do ser, que não é outra coisa senão uma releitura do conceito de intuição categorial, que para Husserl se restringia a um domínio preciso da experiência, e em Heidegger é estendido à totalidade da experiência possível. Heidegger fará dessa aporia seu tema constante. Em Sein und Zeit, mas também nos textos sobre a obra de arte e sobre a poesia. Está aí, como bem lembra Jean-Luc Marion, a diferença primeira entre a leitura das Investigações Lógicas de Heidegger e a leitura que delas faria Derrida em um de seus primeiros ensaios filosóficos, La voix et le phénomène: de modo distinto de Heidegger, que via na sexta investigação e na noção de intuição categorial uma saída possível da metafísica, da ontologia tradicional, e da própria fenomenologia, saída que viria a ser obscurecida pelo pensamento posterior de Husserl, Derrida via já na primeira investigação uma distinção insustentável entre o conceito de expressão e o conceito de indicação que minaria de dentro todo o esquema da fenomenologia e a posicionaria ao lado, em muitos aspectos, da metafísica tradicional, algo como a desconstrução da própria fenomenologia operando já no âmago dela mesma.

Enquanto a fenomenologia buscava penetrar na experiência através de um retorno "às coisas mesmas", Zu den Sachen selbst!, da assunção da experiência

${ }^{10}$ Quanto a esse tema, reportamos ao belíssimo livro de Jean-Luc Marion, Réduction et Donation recherches sur Husserl, Heidegger et la phénoménologie. 
como ela se dá à consciência, prerrogativa sob a qual tudo o que se dá na experiência deve ser aceito enquanto tal, e em que cabe à análise fenomenológica efetuar a suspensão dessa experiência, ainda associada ao conceito de intuição, Heidegger transferia o peso do questionamento para o âmbito de conceitos ditos hermenêuticos, tais como a Compreensão - Verstehen - e a Interpretação Auslegung, conceitos mais abertos às noções de leitura, interpretação, à linguagem e ao sentido enquanto abertura, como viria a escrever posteriormente. Pois o que se verifica quando perscrutamos a experiência e os ditos "dados" da intuição, é que essa doação - esse vir à presença dos dados intuitivos, sejam eles sensíveis ou categoriais - sempre se dá na forma de um excesso: o que equivaleria a dizer, em outros termos, que o ser é diferente do ente. Ou, como Heidegger diria de maneira incisiva, em sua leitura propositalmente enviesada da Sexta Investigação Lógica, texto em que o ser aparece ainda como um tópico secundário:

\begin{abstract}
É também um fato que nossas mais simples percepções e estados constitutivos são expressos, mais ainda, são interpretados de um certo modo. O que é primário e originário aqui? Não tanto que vejamos os objetos e coisas mas sim que primeiramente falemos sobre eles. Para colocá-lo de modo mais preciso: nós não dizemos o que vemos, mas antes o contrário, nós vemos o que se diz sobre o assunto. Esse caráter inerentemente determinado do mundo e sua potencial apreensão e compreensão através da expressividade [Ausdrücklichkeit], por haver sido dito e discutido, é basicamente o que deve ser buscado na questão da estrutura da intuição categorial. ${ }^{11}$
\end{abstract}

Tudo que Husserl buscava na descrição da experiência, na suposta presença inexorável dos dados sensoriais e categoriais, Heidegger situará em um âmbito muito mais complexo, em que o que se encontra no campo concreto da experiência não são intuições ou dados sensoriais, mas apetrechos (o termo Zeug é central em Sein und Zeit), isto é, elementos significantes que só fazem sentido por conta de uma cadeia pré-predicativa mais ampla, e que anunciam e enunciam essa cadeia aberta de significações que torna possível e que é a própria existência do Dasein enquanto sentido. A tentativa de descrever esse âmbito do mundo levará às modificações conceituais presentes na obra principal de Heidegger, então em vias de ser escrita, a muito do que há de radical nessa obra, especialmente no que viria a modificar o modo como compreende-se o sentido. Um dos principais deslocamentos,

${ }^{11}$ HEIDEGGER, Martin. History of the Concept of Time. 
anunciados de passagem nas Investigações Lógicas, e que Heidegger explorará em textos diversos, é quanto ao conceito de verdade.

A verdade, que tradicionalmente estava associada à possibilidade de correspondência entre um enunciado e um estado de coisas, que se resumia no enunciado escolástico "adaequatio intelectus ad rel", ou a adequação do intelecto às coisas, possui em Husserl - ou ao menos na leitura que Heidegger fez de sua obra um status mais amplo, que diz respeito ao âmbito pré-predicativo da verdade, que abre a possibilidade do próprio enunciado. E é em busca desse âmbito prépredicativo aporético, já que é o que dá à experiência seu conteúdo, mas que ao mesmo tempo constrói certa forma de mediação transcendental, expressa por Heidegger com o conceito de "Ausdrücklichkeit" no texto acima, que Heidegger erguerá o edifício em ruínas que é Sein und Zeit. Na fenomenologia heideggeriana, quando descrevemos o que encontramos enquanto dados brutos da experiência, não vemos nunca algo como superfícies, cores, sons e objetos que se fundem na apercepção da experiência, pela atividade sintética do entendimento. Vemos sempre as coisas de um só golpe, como já diz Heidegger no curso do semestre de emergência de 1919, em que se utiliza largamente de exemplos de intenso aspecto fenomenológico, no sentido de apelar à experiência presente e de pedir que seus alunos façam o mesmo:

\footnotetext{
Eu trago uma nova experiência à doação não somente para mim, mas peço que vocês todos, cada Eu-si sentado aqui, façam o mesmo. De fato desejamos, até certo grau, entrar em uma experiência unitária. Como de costume, vocês vem a esta sala no horário costumeiro, e vão para o seu lugar de costume. Foquem nessa experiência de "ver seu lugar", ou coloquem-se em minha posição: vindo à sala, eu vejo a cátedra. Dispensemos uma formulação verbal dessa situação. $O$ que 'eu' vejo? Superfícies marrons, com ângulos específicos uma em relação a outra? Não, eu vejo outra coisa. Uma caixa grande com uma menor situada sobre ela? De modo algum. Eu vejo a cátedra sobre a qual falarei. Vocês vêem a cátedra, da qual vocês serão endereçados, e da qual eu falei para vocês previamente. $\mathrm{Na}$ experiência pura não há interconexão 'fundadora', como se primeiramente eu visse superfícies marrons que se interseccionam, e que então se revelam para mim como uma caixa, então como uma escrivaninha, então como uma cátedra acadêmica, como se eu pregasse o 'ser-cátedra' à caixa, como um selo. Tudo isso é simplesmente má e equivocada interpretação, diversão de um puro perscrutar da experiência. Eu vejo a cátedra de um só golpe, por assim dizer, e não em isolamento, mas como ajustada um pouco alto para mim. Eu vejo - e imediatamente - um livro sobre ela que me irrita (um livro, não uma coleção de páginas em camadas com marcas negras estendidas sobre elas), eu vejo a cátedra em uma orientação, uma iluminação, um plano de fundo. ${ }^{12}$
}

\footnotetext{
${ }^{12}$ HEIDEGGER, Martin. Towards the Definition of Philosophy, p. 56-57.
} 
Nunca encontramos, portanto, no mundo, uma comprovação paulatina das significações das coisas, como se uma "interconexão fundadora" distribuísse e comprovasse as expressões, à maneira, por exemplo, dos significantes matemáticos, em que as significações são dadas à experiência na medida em que essa acontece, como entendia a fenomenologia husserliana, mas "de um só golpe": o mundo, ou, para utilizar os termos de Heidegger de 1919, ainda não lapidados: a "experiência ambiente" já carrega consigo a marca das significações, das sedimentações semânticas que a constituem e, ao mesmo tempo, impedem o acesso a algo como a presença das coisas em si mesmas (ou a existência de algo como um sentido intrínseco às coisas elas mesmas). Heidegger persiste: "Na experiência de ver a cátedra algo é dado a mim de meu ambiente imediato [Umwelt]. Esse milieu ambiental (cátedra, livro, quadro-negro, caderno, caneta, porteiro, fraternidade de estudantes, trem, automóvel, etc.) não consiste somente em coisas, objetos, que são então concebidos como significando isso e aquilo; antes, o significativo é primária e imediatamente dado a mim sem nenhum desvio mental através da apreensão orientada-às-coisas. Viver em um ambiente, isso significa para mim que sempre e por toda a parte tudo tem o caráter de mundo. Por toda parte é o caso que 'isso munda' [es welter] (...)" ${ }^{13}$. Situação aporética por si só, já que o significado ou o sentido das coisas passa a ser o setor mais evidente da experiência, e não sua face obscura, inacessível. Aqui vemos, também, a primeira ocorrência na obra heideggeriana do termo "Umwelt", ou mundo circundante, ambiente circundante, que retornará em momentos cruciais de Sein und Zeit. $O$ fato de que as coisas nos vêm já sempre tingidas de significados, de cristalizações semânticas imperfeitas, nos diz muito sobre o que afasta a fenomenologia heideggeriana da de seu precursor: a redução fenomenológica, tarefa já concebida como infinita e que, segundo os pressupostos dessa crítica e que, como vimos, era uma tentativa de circunscrever o âmbito teleológico e intencional dos atos intencionais e intuitivopreenchedores, para além dessa camada de sedimentações "impuras", permitindo assim a sua descrição, em Heidegger tornar-se-á uma tarefa não somente supérflua, mas infinita: o fulcro do conhecimento deixa de ser a percepção, e sua suposta descrição para além da interferência da atitude natural, e torna-se a interpretação, ou a hermenêutica enquanto arte da interpretação, já que não há mais uma

${ }^{13}$ Towards the Definition of Philosophy, p. 58. 
experiência de fundo, livre de toda significação, de toda semântica, de toda distorção do mundo, já que mundo é tudo que há, já que é sempre o mundo, e nunca o "em parte alguma".

O que equivale a dizer, nos termos de Sein und Zeit, que a enunciação (Aussage) é derivada da interpretação (Auslegung). O aparato teórico esboçado nos cursos adquire no livro o formato acabado da inversão entre o enunciado e a interpretação, posição que evoluiria, anos depois, para a famosa sentença presente na Carta sobre o humanismo: "a linguagem é a morada do ser". Isto é, embora em 1927 Heidegger ainda subordine a linguagem (Sprache) ao discurso (Rede), já há aí um esboço de como a questão da linguagem e do sentido viria a ser tratada nos anos seguintes, em que a linguagem e a enunciação assumem o primeiro plano. Esse modo de lidar com a questão do sentido e da linguagem influenciará de maneira decisiva não só parte substancial da fenomenologia e literatura francesas, mas também a obra de Maurice Blanchot, em especial sua experiência ficcional.

Tratar-se-á da inexorabilidade do sentido com cada vez mais atenção. 


\section{Capítulo II - Da questão da literatura}


Nunca temos diante de nós o espaço puro, nem mesmo um único dia, para onde as flores desabrocham sem fim - Sempre é o mundo e nunca o em-parte-alguma, sem nada: o puro, o inesperado, que se respira e sabe infinito, sem cobiça.

- Rilke. ${ }^{14}$

"Peut-être faut-il dire que l'artiste, cet homme que Kafka voulait être aussi, en souci de son art et à la recherche de son origine, le 'poète' est celui pour qui il n'existe pas même un seul monde, car il n'existe pour lui que le dehors, le ruissellement du dehors éternel. 》

- Maurice Blanchot ${ }^{15}$

A literatura, para Blanchot, habita o limite e carrega consigo a questão do limite. Tanto sua literatura como seu discurso crítico insere-se nesse registro da necessidade do estrangeiro, do estranho que não se deixa situar segundo os limites da inteligibilidade, do mundo, que não se deixa perscrutar sob a face do dia. Este outro, que para Levinas é a condição crítica de toda possibilidade de linguagem e de todo mundo, como em Totalidade e Infinito, em que critica Heidegger justamente por sua noção de horizonte, entendido aqui como o horizonte neutro e impessoal que antecede toda significação. A literatura blanchotiana parte do pressuposto, mais radical, de que uma relação com o outro é impossível; ou poderíamos dizê-lo de outra forma: no que diz respeito a sua obra, há relação com um outro, mas essa relação é compreendida como distanciamento infinito, como a incapacidade de percorrer a distância infinita estendida entre o um e o outro, ou como incapacidade do mesmo de preencher os nexos significativos de sua própria linguagem, uma relação precisamente impossível, isto é, que excede o quadro do possível. A literatura, na obra de Blanchot, é essa curiosa arte das antecâmaras, em que personagens espectrais (dos quais nem o leitor, nem Blanchot, nem eles mesmos conhecem os desígnios) são obrigados a efetuar travessias inúteis, a passar por umbrais e corredores vazios que não levam a lugar algum; em que o próprio narrador não sabe dizer o que se passa com seus personagens, que desconhece por completo; esses romances, enfim, sobre o nada, mas sobre a parcela do nada que não edifica, sobre as cercanias das clareiras do possível, que não participam do

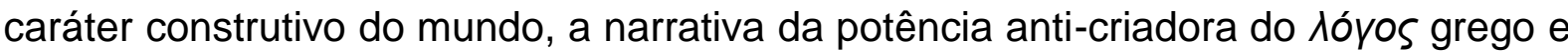
cristão, a literatura edificada sobre as ruínas do que o movimento da dialética não pode sublimar; esse é o romance de Blanchot, e essa é sua ficção. Basta folhear as

${ }^{14}$ RILKE, Rainer Maria. Sonetos a Orfeu-Elegias de Duíno. Bragança Paulista: Editora Universitária São Francisco, 2005.

15 "Talvez seja necessário dizer que o artista, este homem que Kafka queria ser também, em vista de sua arte e à busca de sua origem, o 'poeta' é aquele para quem não existe mesmo um só mundo, pois não existe para ele senão o fora, o escoamento do fora eterno." (BLANCHOT, 1955, p. 81) 
primeiras páginas de Thomas l'obscur ou de Aminadab para perceber que se trata de uma escritura em que o que é posto em questão é o próprio estatuto da escritura, do romance, da narrativa, enfim.

Mas não basta dizer isto do romance de Blanchot: como afirmou Georges Poulet, o "universo" literário de Blanchot é um universo "vestibular", um mundo oco, uma escritura em que tanto o leitor com o próprio protagonista do romance são postos diante da necessidade e da possibilidade da tarefa infinita da redução, ou da impossibilidade e necessidade de leitura e interpretação do texto. Constrói-se aqui uma relação outra com o sentido, no esteio da leitura particularíssima da filosofia heideggeriana e do modo como essa entende a linguagem e o sentido: trata-se de um mundo feito de vestíbulos, de corredores que não levam a lugar algum, de espaços que são perpetuamente percorridos e que nunca levam a estadia alguma, qualquer que seja. Esta é, de fato, uma das características fundamentais das narrativas de Blanchot e da topologia que nelas se esboça. Encontramos referências a esses corredores mal iluminados, a esses espaços obscuros constantemente percorridos em vão, citados por Poulet e por Michel Foucault ${ }^{16}$, em praticamente todas as obras "literárias" de Blanchot, de que podemos mencionar o exemplo de Aminadab, de 1943, de que colhemos ao acaso alguns exemplos:

\begin{abstract}
Il pénétra dans un couloir long et spacieux où il fut surpris de ne pas voir tout de suite l'escalier. D'après ses calculs, la chambre qu'il cherchait se trouvait au troisième étage, peut-être même à un étage supérieur; il avait hâte de s'en rapprocher en montant aussi vite que possible. Le couloir semblait sans issue. II le parcourut rapidement et en fit le tour. Puis, revenu à son point de départ, il recommença, en ralentissant cette fois le pas et en se collant contre la cloison dont il suivait les anfractuosités. (BLANCHOT, 1942, p. 9) ${ }^{17}$
\end{abstract}

II suivit le jeune homme qui l'entraîna dans un couloir sombre où l'obscurité ne l'empêcha pas de marcher avec rapidité. De chaque côté du couloir, il y avait des portes qui ressortaient dans l'ombre à cause de la couleur noire dont elles étaient recouvertes. Thomas ne pouvait pas voir grand-chose. L'une de ses mains était liée au poignet gauche du nouveau venu qui le tirait en avant sans précaution. Après quelques pas d'une démarche saccadée, le couloir se resserra et il ne fut plus possible d'avancer. (BLANCHOT, 1942, p. 25) ${ }^{18}$

\footnotetext{
${ }^{16}$ POULET, Georges. Maurice Blanchot, Critique et Romancier. Revue Critique, № 229, Paris, Junho de 1966.

17 "Ele penetrou em um corredor longo e espaçoso em que ficou surpreso de não logo ver a escada. Por seus cálculos, o quarto que ele buscava se encontrava no terceiro andar, talvez mesmo em um andar superior; ele tinha presa de se aproximar, subindo tão rápido quanto possível. $\mathrm{O}$ corredor parecia sem saída. Ele o percorreu rapidamente e deu a volta. Então, de volta a seu ponto de partida, ele recomeçou, desacelerando dessa vez o passo e colando-se ao anteparo do qual seguia as imperfeições."

18 "Ele seguiu o jovem homem que o arrastou a um corredor sombrio em que a obscuridade não impediu de caminhar com rapidez. De cada lado do corredor, havia portas que surgiram na sombra
} 
Como no primeiro exemplo, os personagens raramente são capazes de enxergar o todo dos espaços de Blanchot, assim como raramente são capazes de perscrutar onde terminam esses espaços. E são constantemente levados a recomeçar a travessia, a passagem por esses espaços, como no segundo exemplo. Há na própria construção desses espaços uma posição em relação à questão do sentido, como buscaremos demonstrar no momento oportuno.

Além de Poulet, Sartre também assinalou - em um artigo talvez algo desatento, mas que permanece sendo, com toda sua virulência, uma poucas e incisivas análises da narrativa de Blanchot - a curiosa inversão presente em sua literatura, que diz respeito especialmente a sua filiação ao "fantástico": pois, segundo Sartre, os escritos de Blanchot - e os de Kafka - não são simplesmente absurdos, dado que o absurdo seria a ausência total de qualquer fim, e seria ainda o objeto possível de um pensamento que se posiciona ainda diante de um objeto, o construto do pensamento soberano de um sujeito soberano, o que tornaria o absurdo ele mesmo um dos objetos possíveis do sentido, absorvido pelo horizonte do mundo. $A$ literatura do absurdo, portanto, produziria ainda um sentido residual. É justamente o que está em questão na obra ficcional de Blanchot. Em Blanchot, de modo radicalmente distinto, o que vemos é uma possibilidade dupla: tanto a reserva do aniquilamento do sentido (o sentido sempre pode perder-se de súbito), como o sentido que se mantém em reserva, inevitável (o assombro do sentido possível, sempre presente). Nos seus relatos certos fins são perseguidos, mas são fins de que nem os personagens nem os leitores tomam consciência, e não existe para o pensamento, nesses textos, a possibilidade de totalizar a coisa narrada e o relato em um só tecido. ${ }^{19}$ Experiência, portanto, de um espaço limitado, percorrido incessantemente, e também experiência de um tempo "hors temps", desde sempre já iniciado, recomeço que é a única possibilidade do relato, um passado absoluto e um presente inexoravelmente atravessado pelo devir, esse é o tempo do récit

por conta da cor negra da qual eram revestidas. Thomas não podia ver grande coisa. Uma de suas mãos estava ligada ao punho esquerdo do novato que o puxava para adiante sem precaução. Depois de alguns passos de uma marcha irregular, o corredor se fechou novamente e não foi mais possível avançar."

${ }_{19}$ “(...) No mundo maníaco e alucinante que tentamos descrever o absurdo seria um oásis, um repouso, de modo que aí não há lugar algum para ele. Nesse mundo não posso me deter por um só instante: todo meio me remete sem descanso ao fim fantasmagórico que o assombra e todo fim me reenvia ao meio fantasmagórico pelo qual eu poderia realizá-lo. Não posso pensar coisa alguma, a não ser por noções escorregadias e cintilantes que desagregam sob meu olhar." - SARTRE, JeanPaul. Situações, Vol. 1: Críticas Literárias. São Paulo: Cosac \& Naify, 2006, p. 140. 
blanchotiano - sempre tarde demais, sempre cedo demais. A tentativa de relatar 0 irrelatável leva às dobras da linguagem, e aos seus limites, no intento talvez ingênuo de que assim possam ser ultrapassados. Esta borda, contudo, não se desfaz de bom grado; não é simples a superação dos limites, não se trata de uma linha que se pudesse simplesmente romper. Há aí uma questão de "método".

Não basta, por exemplo, que a linguagem literária se torne totalmente opaca, impenetrável, de modo que a experiência - a experiência da literatura, se podemos ainda falar de "experiência" nesse caso - seja apenas a experiência do ser "bruto, escarpado" da linguagem, para utilizar uma vez mais os termos de Foucault, em que a linguagem dobra sobre si mesma e torna-se sólida como um bloco, de modo frontalmente oposto à linguagem do realismo, que pretendia tornar-se tão transparente quanto possível, e mostrar, no que possuía de translúcido, o evento em si, o relatado (supondo que fosse possível dizer o mínimo necessário e assim conter o deslizamento do significante). Blanchot sempre tratou da linguagem literária partindo de uma concepção semelhante à de Mallarmé, como se nota desde Faux Pas até L'Entretien Infini, e mesmo em seus últimos livros, no que diz respeito à diferença entre a linguagem cotidiana e a linguagem literária. No começo de sua obra ainda se conserva, em certa medida, como podemos ler em La Part du Feu, de 1949, essa divisão clara entre os dois registros da linguagem (que é antes uma diferença de grau, mas, como toda diferença de grau, uma diferença ontológica), mas já nessa segunda coletânea de ensaios a linguagem, mesmo a linguagem cotidiana, que pretende-se suficiente para o que diz, que pretende, enfim, estabelecer uma ordem entre as palavras e as coisas que elas "representam" - não pode ser contida em seus limites:

(...) Comment l'absence infinie de la compréhension pourrait-elle accepter de se confondre avec la présence limitée et bornée d'un mot seul? Et le langage de chaque jour qui veut nous en persuadér ne se tromperait-il-pas? En effet, il se trompe e il nous trompe. La parole ne suffit pas à la vérité qu'elle contient. Qu'on se donne la peine d'écouter un mot, en lui le néant lutte et travaille, sans relâche il creuse, s'efforce, cherchant une issue, rendant nul, ce qui l'enferme, infinie inquiétude, vigilance sans forme et sans nom. Déjà le sceau qui retenait ce néant dans les limites du mot et sous les espèces de son sens s'est brisé; voici ouvert l'accès d'autres noms, moins fixes, encore indécis, plus capables de se concilier avec la liberté sauvage de l'essence negative, des ensembles instables, non plus des termes, mais leur mouvement, glissement sans fin de "tournures" qui n'aboutissent nulle part. - (BLANCHOT, 1949, p. 315) ${ }^{20}$

20 "Como a ausência infinita da compreensão poderia aceitar se confundir com a presença limitada e delimitada de uma só palavra? E a linguagem de cada dia que vem nos persuadir não se enganaria? Com efeito, ela se engana e nos engana. A palavra não basta à verdade que ela contém. Que se dê 
O relato fundado nesta linguagem que rompeu o receptáculo da palavra não pode mais aceitar o simples convívio com a estrutura tradicional da narrativa ${ }^{21}$, em que os personagens têm vontades, anseios, características delimitáveis de uma subjetividade, de um sujeito soberano no qual se confundem as pessoas do escritor, do personagem e do leitor. O mundo relatado nessas narrativas é críptico, opaco, mas somente até certo ponto. Pois a narrativa deve dar a ambos, leitor e personagem, alguma chave para sua decifração, algo como uma senha que desse acesso à antecâmara do relato; mas nunca a chave que permita decifrar por completo do relato, que permita o comentário, que permita dizer, por exemplo, o que se passou no relato, o que foi relatado, de que experiência se dá testemunho. Pois o relato (aqui, no sentido de récit), em Blanchot, não é relato de um acontecimento da experiência, isto é, não dá a ver essa experiência, qualquer que seja, isto é, nele a linguagem não chega nunca a garantir a transparência absoluta do relato, mas também nunca se materializa por completo, nunca se torna totalmente opaca, nãoportadora de sentido. Um mundo profundamente estranho, de fato, mas um mundo talvez mais estranhamente ainda - em certa medida compreensível.

Diz Levinas em Totalidade e Infinito que a palavra orienta o mundo, dotando-o de significação. Pois é através da palavra que "(...) o sistema de reenvios a que se reduz toda a significação recebe o princípio do seu próprio funcionamento, a sua chave"22. Para o filósofo, a palavra - expressa no rosto do outro, no contato "imediato" com o rosto do outro - é a promessa sempre renovada de esclarecer o que nela havia de obscuro, promessa da vinda do mundo à proposição, "retomada do que foi um simples sinal lançado por ela". Para Blanchot, como se pode notar, o evento que se dá na palavra é também uma promessa, mas que se dá estritamente

com dificuldade o esforço de escutar uma palavra, nela o nada luta e trabalha, sem descanso ele cava, se esforça, buscando uma saída, tornando nulo isso que o enclausura, infinita inquietude, vigilância sem forma e sem nome. Já o selo que retia esse nada nos limites da palavra e sob as espécies de seu sentido se rompeu; eis aberto o acesso a outros nomes, menos fixos, ainda indecisos, mais capazes de se conciliar com a liberdade selvagem da essência negativa, dos conjuntos instáveis, não mais termos, mas seu movimento, deslizamento sem fim de 'volteios' que não terminam em parte alguma."

${ }^{21}$ Subscrevemos, aqui, a posição de Manola Antonioli em seu livro sobre a ficção e a teoria do récit em Blanchot: "O que a dizer quando todas as garantias da linguagem e do récit foram revogadas? A linguagem é devolvida a seu perigo, à sua desordem original ; ela solicita e interroga seus limites, mas não pode fazê-lo senão através de palavras, em um récit que coloca a questão mesma do récit, da fábula, da narração. É esse o paradoxo recorrente da busca de Blanchot: trata-se de pôr em questão o espaço da literatura, o espaço do livro, a dimensão de uma linguagem regulada e das regras da linguagem, tudo dentro de um discurso herdeiro desses códigos, dessas estruturas, de uma certa organização do sentido."- ANTONIOLI, Manola. L'Écriture de Maurice Blanchot: Fiction et Théorie. Paris: Éditions Kimé, 1999, p. 25.

22 LEVINAS, Emmanuel. Totalidade e Infinito. Lisboa: Edições 70, 2008, p. 89. 
enquanto promessa, isto é, que não promete o além da promessa. $O$ fato de a palavra trazer consigo a promessa sempre renovada de esclarecimento do que ficou obscuro na última palavra, do comentário que vem para trazer luz ao hermetismo dos textos obscuros configura a maior prova, para Blanchot, do caráter paradoxal da própria linguagem (resumida em certos momentos na palavra "palavra", "mot"). Ou poderíamos dizer, uma vez mais opondo sua posição à de Levinas: em Blanchot, e especialmente em sua ficção, há ênfase no aspecto indicativo da linguagem. Tratase, aqui, de uma linguagem que não revela e tampouco oculta. $O$ espaço descrito por esse discurso é, talvez, ainda o espaço de uma revelação, é ainda, talvez, o de um acontecimento da verdade, mas de uma revelação do próprio limite, de um acontecimento da verdade enquanto limite: para Blanchot, a literatura é, ao lado do exílio bíblico, o lugar da "errância"; e, na errância, nada se abre, nada está fechado, e portanto não há horizonte algum ${ }^{23}$.

O relato, nesse caso, não é um ente à parte do que relata: é precisamente o acontecimento do relato que é relatado. No espaço do relato as distâncias não são delimitadas com clareza, e tampouco é situado o sujeito, ou esse não participa ao modo da visão, as coisas não se mostram, não se apresentam - não mais do que não se ocultam. Nessa concepção da linguagem, o relato, diferentemente do romance, que seria ainda o relato de um acontecimento, de uma experiência, é o próprio acontecimento, como Blanchot viria a dizer em "Le chant des sirènes" (Le livre à venir), ensaio em que opõe, de certo modo, o roman ao récit: "Cependant, le caractère du récit n'est nullement pressenti, quand on voit en lui la relation vraie d'un événement exceptionnel, qui a eu lieu et qu'on essaierait de rapporter. Le récit n'est pas la relation de l'événement, le lieu où celui-ci est appelé à se produire, événement encore à venir et par la puissance attirante duquel le récit peut espérer, lui aussi, se réaliser." ${ }^{24}$. Esta é talvez a contribuição maior da escritura de Blanchot para uma fenomenologia da experiência literária, e uma de suas formas condensadas se mostra de forma mais intensa no relato que, editado uma vez sem nome em 1949, ganhou na segunda, em 1973, o nome de La Folie du Jour, embora já se mostre nos primeiros ensaios de Blanchot no campo da literatura.

\footnotetext{
${ }^{23}$ BLANCHOT, Maurice. L'Entretien Infini. Paris: Gallimard, 1969, p. 36.

24 "Entretanto, o caráter do récit não é em nada percebido quando nele se vê o relato verdadeiro de um acontecimento excepcional, que teve lugar e que se tenta relatar. O récit não é o relato do acontecimento,o lugar onde ele é chamado a produzir-se, acontecimento ainda por vir e que pela potência atrativa do qual o récit pode esperar, ele também, realizar-se." (BLANCHOT, 1999, p. 14)
} 
À questão da literatura, portanto, sempre foi associada uma certa questão do limite em Blanchot, do limite da experiência ou da experiência do limite. A própria noção de experiência limite, tal como Blanchot a lia em Bataille - especialmente no ensaio que porta esse nome, 'L'Expérience Limite", presente em L'Entretien Infini, assinala esse caráter liminar do próprio espaço literário. A experiência limite é a experiência, de certo modo, de um outro que não se deixa absorver. É esse "étrange surplus" anterior à própria experiência, que impede que ela aproprie-se de si mesma, pois quando o "homem" ou o escritor constrói o mundo do dia, da inteligibilidade, e dá sentido às coisas, essa decisão - e é de uma decisão que se trata, sempre - é de antemão sulcada por um excesso, inscrita por este "evento que não pertence à possibilidade", que excede mesmo o trabalho da potência da linguagem erguendo o mundo do sentido e o sentido do mundo. E é esse excesso que, junto a todos seus espectros e consequências, pode ser entendido como a grande constante da ficção e da ensaística de Blanchot - excesso que abre no ser realizado e finito um "ínfimo interstício" (é necessário prestar atenção aos orifícios, corredores, escadarias, os espaçamentos, enfim, da obra de Blanchot) pelo qual o sentido transborda, rompendo o limite sem rompê-lo, relação dupla que faz com que tudo que é compreendido, totalizado, dominado, tudo que dá e que recebe o sentido seja excedido de antemão por esse "acréscimo de negatividade" ${ }^{25}$. Ao referir-se à noção de Bataille de experiência "interior" formulada por Bataille, Blanchot diz:

(...) Et cependant l'expérience intérieure exige cet événement qui n'appartient pas à la possibilité; elle ouvre en l'être achevé un infime interstice par où tout ce qui est se laisse soudainement déborder et déposer par un surcroît qui échappe et excède. Étrange surplus. Quel est cet excès qui fait que l'achèvement serait encore et toujours inachevé? D'où vient ce mouvement d'excéder dont la mesure n'est pas donné par le pouvoir qui peut tout? Quelle est cette 'possibilité' qui s'offrirait après la réalisation de toutes les possibilités comme le moment capable de les renverser ou de les retirer silencieusement ? (BLANCHOT, 1969, p. 307) ${ }^{26}$

\footnotetext{
${ }^{25}$ Não é a intenção do presente trabalho, mas vale assinalar, como outros o fizeram detalhadamente, a importância das lições sobre a Fenomenologia do Espírito e a obra de Hegel em geral de Alexandre Kojève, ministradas nos anos 30 e por tantos assistidas, em um certo enriquecimento da noção de negatividade.

${ }_{26}$ " $E$ no entanto a experiência interior exige este acontecimento que não pertence à possibilidade; ela abre no ser realizado um ínfimo interstício por onde tudo isso que é se deixa subitamente transbordar e depôr por um excesso que escapa e excede. Estranho surplus. Que é esse excesso que faz com que a realização seja ainda e sempre irrealizada? De onde vem esse movimento de exceder cuja mesura não é dada pelo poder que pode tudo? Qual é esta 'possibilidade' que se ofereceria após a realização de todas possibilidades como o momento capaz de invertê-las ou retirá-las silenciosamente?"
} 
É também nesse sentido que se pode dizer que toda experiência é uma experiência liminar. Pois somos obrigados a viver sob o duplo registro do dia: ora o mundo do sentido e da inteligibilidade, ora a face noturna de toda presença, a face obscura da realidade a que Levinas fez referência em La réalité et son ombre ${ }^{27}$, ensaio que certamente influenciou a escrita de Blanchot e sua ontologia da linguagem e da obra de arte. Assim como diversos outros conceitos de sua obra crítica, há uma ambiguidade irredutível nas múltiplas experiências da linguagem. É o caso, talvez, de todos seus romances e de todas suas narrativas. Especialmente da que recebeu o nome de La Folie du Jour, que incorpora em uma narrativa extremamente densa e curta alguns dos temas fundamentais de Blanchot, com que lidaremos em pormenores em capítulo próprio a seguir.

Em La Folie du Jour somos apresentados, de súbito, ao relato. A sentença que destacamos a seguir dá início à narrativa:

Je ne suis ni savant ni ignorant. J'ai connue des joies. C'est trop peu dire: je vis, et cette vie me fait le plaisir le plus grand. Alors, la mort? Quand je mourrai (peut-être tout à l'heure), je connaîtrai un plaisir immense. Je ne parle pas de l'avant-goût de la mort qui est fade et souvent désagréable. Souffrir est abutissant. Mais telle est la vérité remarquable dont je suis sûr: j'éprouve à vivre un plaisir sans limites et j'aurai à mourir une satisfaction sans limites. - (BLANCHOT, 2006, p. 9) 28

O relato, aparentemente, é autobiográfico: fala-se de uma vida aparentemente vulgar, de alguém que foi rico, que foi pobre; que amou, que possuiu, e que perdeu; que urrou, vagou pelas ruas vazias, um participante, enfim, da loucura e da ruína do mundo, de alguém que viveu e participou da ruína do mundo. Alguém, enfim, que encontrou satisfação na ordem das coisas, na ordem visível das coisas. Alguém que, como Dostoiévski, como Blanchot, viveu o momento da iminência maior, o da iminência de uma execução por fuzilamento não levado a cabo. Alguém satisfeito

\footnotetext{
27 “'Um ente é aquilo que é, aquilo que revela a si mesmo em sua verdade, e, ao mesmo tempo, que assemelha-se a si, é sua própria imagem. O original se dá como se numa distância de si mesmo, como se estivesse fazendo a si mesmo recuar, como se algo no ser estivesse em atraso atrás do ser. A consciência da ausência do objeto que caracteriza a imagem não é equivalente à simples neutralização da tese, como proporia Husserl, mas é equivalente a uma alteração no ser mesmo do objeto, onde suas formas essenciais aparecem como um traje que ele abandona em seu recuo." (LEVINAS, 1987, p. 6-7)

28 "Não sou nem sábio nem ignorante. Conheci alegrias. É dizer muito pouco: vivo, e esta vida me causa o maior dos prazeres. Quando eu morrer (talvez nesse instante), conhecerei um prazer imenso. Não falo do antegosto da morte, que é insípido e no mais das vezes desagradável. Sofrer é embrutecedor. Mas tal é a verdade notável da qual estou certo: experimento em viver um prazer sem limites e terei em morrer uma satisfação sem limites."
} 
com o devir das coisas, com a vida e com a morte, com a infinitude e a finitude das coisas. Mas, também subitamente, esse alguém passa por um acontecimento traumático, que é impossível determinar com clareza qual: uma experiência limítrofe, se nos é permitido dizê-lo. Atiram-lhe vidro nos olhos. Esse acontecimento tornará todo o relato impossível. Nesse momento o narrador é como que acometido pela incapacidade de relatar, mas, no entanto, é outro o desenrolar da história, em que ele deverá, de todo modo, dar testemunho de sua experiência: dizer o que aconteceu, em suma.

Figuras da autoridade e da lei exigem do personagem que ele relate tudo que se passou, exigem o testemunho do que aconteceu, antes de tudo e especialmente o evento traumático em que acabou por ferir seus olhos e sua visão, que o afastou da experiência do dia (que tornou o dia excessivamente luminoso doravante, impassível de estadia). Médicos lhe questionam: inquirido, o narrador diz que não pode relatar, não pode agir segundo a vontade da lei, não pode dar testemunho do que se passou. Quando, por fim, sucumbe à vontade das autoridades, essas pretendendo descobrir "o que se passou de fato", excluindo assim toda possibilidade de segredo, o narrador enuncia as seguintes palavras:

On m'avait demandé: Racontez-nous comment les choses se sont
passées 'au juste'. - Un récit? Je commençai: Je ne suis ni savant ni
ignorant. J'ai connu des joies. C'est trop peu dire. Je leur racontai
l'histoire toute entière qu'ils écoutaient, me semble-t-il, avec intérêt, du
moins au début. Mais la fin fut pour nous une commune surprise. 'Après
ce commencement, disaient-ils, vous en viendrez aux faits.' Comment
cela! Le récit était terminé. - (BLANCHOT, 2006, p. 29)

No momento de relatar, ou seja, no momento da consumação do récit, o texto repete as mesmas palavras com que começa o próprio relato que o leitor tem em mãos, há vinte páginas. O récit que estamos lendo, e essa narrativa sobre um acontecimento que deixa o narrador cego, incapaz de relatar, é a narrativa do próprio acontecimento da narrativa; mas não da narrativa enquanto adequatio do relato com a experiência de que pretende dar conta, não a narrativa enquanto o acontecimento da verdade, em que ela é sempre capaz de relacionar-se com os entes a que se refere, em que a verdade é a própria coincidência do relato com o

\footnotetext{
29 "Perguntaram-me: diga-nos como as coisas se passaram 'de fato'. - Uma narrativa? Eu começava: não sou nem sábio nem ignorante. Conheci alegrias. É dizer muito pouco. Eu Ihes contava a história inteira que eles escutavam, me parece, com interesse, ao menos no início. Mas o fim foi para nós uma surpresa comum. 'Após esse início, diziam eles, você virá aos fatos.' Como isso! A narrativa estava terminada."
} 
que o relato relata; mas sim a narrativa que é a própria disjunção entre relato e experiência, disjunção do relato que cinde tanto o relato como a experiência que ele relata. E a prova maior da disjunção é que o récit que o leitor tem em mãos, Ihe é revelado no final da narrativa, é o récit que o narrador inicia quando uma das figuras da lei lhe exige que diga a verdade, que diga o que aconteceu. O relato, portanto, já havia iniciado, já é ele mesmo um recomeço, isso mesmo quando se o lê pela primeira vez. E o fim aparente também é provisório, dado que retoma o início do relato, evidenciando a impossibilidade do testemunho, e, por que não, dando testemunho - um testemunho impossível - da impossibilidade do testemunho. Situação liminar, por certo: um narrador incapaz de narrar, um relato que hesita em produzir sentido, mas ainda um relato.

Esta pequena porém incisiva "mise en abyme", ao lado de outros recursos, coloca o leitor no contato impossível com o próprio espaço literário, o espaço do récit que, não mais pretendendo reproduzir ou replicar o espaço do mundo, como o vidro que funciona como lente, isto é, em que a linguagem é perfeitamente transparente para o que pretende representar (tornar presente uma vez mais), mas um espaço em que o vidro, introjetado nos olhos, introduz uma disjunção essencial entre a visão e a linguagem. O vidro impede o olho de agir enquanto olho, como o forro do fundo de um espelho que cria a reflexão ${ }^{30}$, a reflexão infinita, que não permite nunca que o relatum encontre, de fato, seu referente. Interrupção do circuito do mundo, suspensão dos limites entre a linguagem e o que supostamente ela "representa". Esse artifício e estrutura são recorrentes, como veremos, na obra ficcional de Blanchot, em especial nas que analisaremos no presente trabalho.

O que dizemos aqui de Blanchot vale, talvez, para toda a literatura influenciada pela obra de Martin Heidegger. Foi Heidegger que inverteu, em sua leitura da fenomenologia, a noção de que a verdade corresponde à adequação entre o juízo apofântico e um determinado estado de coisas. Já não se trata, nesse registro da ficção, de meramente inverter os termos dessa noção de verdade, e de mostrar assim o âmbito pré-predicativo, ontológico, da "verdade do ser", que

\footnotetext{
${ }^{30}$ Jacques Derrida diz, referindo-se à literatura de Mallarmé, algo que é perfeitamente válido também para a literatura de Blanchot, em especial La Folie du Jour. "(...) Nesse speculum sem realidade, nesse espelho de espelho, há bem uma diferença, uma dyade, já que há mímica e fantasma. Mas é uma diferença sem referência, ou, sobretudo, uma referência sem referente, sem uma unidade primeira ou última, fantasma que não é o fantasma de alguma carne, errante, sem passado, sem morte, sem nascimento nem presença." - DERRIDA. La Dissemination. Paris: Éditions du Seuil, 1972, p. 255.
} 
corresponderia totalmente ao "ser da verdade". Como Levinas já havia assinalado em um de seus ensaios sobre Blanchot, o vidro que se aloja nos olhos do narradorpersonagem - que mencionamos anteriormente - é uma imagem precisa do acontecimento da verdade do mundo levando essa verdade mesma ao paroxismo, evento em que o leitor é levado à face fulgurante do dia, à experiência da luz excessiva que não permite que se enxergue, que se defina com clareza os contornos, que não torna visível forma e conteúdo. A abertura da verdade, do mundo visível, torna-se, por assim dizer, demasiado obtusa em Blanchot. A claridade, aqui, queima as retinas de quem a experimenta. E é este o "símbolo central" da narrativa, segundo Emmanuel Levinas. ${ }^{31} \mathrm{O}$ dia que fere os olhos de quem o enxerga é o dia da reiteração, da repetição infinda da narrativa, do acontecimento propriamente mimético da literatura. Poder-se-ia falar, em termos fenomenológicos, de um evento no qual o personagem não consegue dar conta de seu mundo, mas é obrigado a viver sob seu signo. Um relato, enfim, em que é narrado um evento inapropriável sob o horizonte do mundo. Um nexo de significação, como foi dito, mas o nexo do próprio ser enquanto limite. Como Blanchot já havia dito em La Littérature et le Droit à la Mort, um dos ensaios cruciais reunidos em La Part du Feu, o dia da literatura não é o dia enquanto transparência, desvelamento da verdade do ser, mas o dia enquanto inevitabilidade, enquanto impossibilidade de cessar a visão. Como escapar ao domínio do sentido? Qual a literatura, se há, que dará testemunho do impossível sentido do que não se dá sob o horizonte do sentido? Como operar sob o registro duplo da linguagem, dado que esta é a linguagem que edifica o próprio dia? Seria mesmo possível escapar à negatividade realizadora presente na linguagem?

En niant le jour, la littérature reconstruit le jour comme fatalité; en affirmant la nuit, elle trouve la nuit comme l'impossibilité de la nuit. C'est là sa découverte. Quand il est lumière du monde, le jour nous rend clair ce qu'il nous donne à voir il est pouvoir de saisir, de vivre, réponse «comprise » dans chaque question. Mais si nous

\footnotetext{
31 "Mas o dia não é somente a sincronia do sucessivo, a presença onde o tempo se abisma, onde se envolve nas horas sem que nele nada se obscureça, e onde o escurecimento mesmo tem sua hora; 0 dia não é somente a ênfase de uma existência que, à força de ser, se mostra e ressoa e resplandece em consciência. Enquanto claridade e visão, a consciência é também uma modalidade do ser que toma distância com relação a si mesmo, representação que já não pondera a si mesma atendo-se à sua própria medida na transparência da verdade. Que esta abertura da verdade - esta claridade que advém na transparência do vazio - possa ferir a retina como um cristl que se rompe sobre esse olho aguçando sua vista, e que essa feriada seja buscada, não obstante, como lucidez e desencantamento, eis aí novamente em que consiste a loucura do dia. Iteração infinitamente repetida da loucura desejada como luz do dia que fere o olho que o busca. 'A ponto estive de perder a vista, por alguém haver me jogado cristal sobre os olhos' - aqui temos o símbolo central da Loucura do dia." (LEVINAS, 2000, p. 85)
} 
demandons compte du jour, si nous en venons à le repousser pour savoir ce qu'il y a avant le jour, sous le jour, alors nous dévouvrons qu'il est déjà présent, et ce qu'il y a avant le jour, c'est le jour encore, mais comme impuissance à disparaître et non comme pouvoir de faire apparaître, obscure nécessité et non liberté éclairante. La nature donc de ce qu'il y a avant le jour, de l'existence prédiurne, c'est la face obscure du jour, et cette face obscure n'est pas le mystère non dévoilé de son commencement, c'est sa présence inévitable, un " II n'y a pas de jour " qui se confond avec un "II y a déjà du jour », son apparition coïncidant avec le moment où il n'est pas encore apparu. Le jour, dans le cours du jour, nous permet d'échapper aux choses, il nous les fait comprendre et, en nous les faisant comprendre, il les rend transparentes et comme nulles; mais le jour est ce à quoi on n'échappe pas : en lui nous sommes libres, mais lui-même est fatalité, et le jour comme fatalité est l'être de ce qu'il y a avant le jour, l'existence dont il faut se détourner pour parler et pour comprendre.(BLANCHOT, 1949, p. 318) ${ }^{32}$

É da visão que a palavra nos liberta, diz Blanchot, pois o próprio conceito de palavra - e alguns que the são coextensos - é responsável pela derrubada de um certo paradigma ótico da tradição ocidental do pensamento. Pois a visão supõe a separação, e a separação que a noção de horizonte sugere, isto é, a separação que opera enquanto mediação entre a distância e a presença; como a linguagem cotidiana que supõe transparecer o ser das coisas, a ênfase na visão supõe a transformação da distância em imediata, em "i-mediatriz", nos termos de Blanchot, trazendo ao olho a presença total de um horizonte, em que a linguagem é toda ela preenchida por significações que se preenchem de intuições. A visão define com clareza os seus limites. É por isso, talvez, que "falar não é ver", como insiste Blanchot: enquanto a visão nos retém nos limites de um horizonte, o próprio ser da palavra opera por desorientação, suspendem a relação entre a percepção e o horizonte de sentido que lhe é inexorável, contra a soberania do olhar. "la terrible parole passe outre à toute limite et même à l'illimité du tout", nos diz Blanchot. São vários os textos que exploram esse aspecto central da obra de Blanchot, e que diz

\footnotetext{
32 "Negando o dia, a literatura reconstrói o dia como fatalidade ; afirmando a noite, ela encontra a noite como impossibilidade da noite. Está aí sua descoberta. Quando ele é luz do mundo, o dia nos torna claro isso que ele nos dá a ver, ele é poder de discernir, de viver, resposta 'compreendida' em cada questão. Mas se nós pedimos conta do dia, se nós queremos fazer-Ihe recuar para saber o que há antes do dia, sob o dia, então nós descobrimos que ele é já presente, e o que há antes do dia, é o ainda o dia, mas como impotência a desaparecer e não como potência de fazer aparecer, obscura necessidade e não liberdade esclarecedora. A natureza então disso que há antes do dia, da existência pré-diurna, é a face obscura do dia, e essa face obscura não é o mistério não desvelado de seu começo, é sua presença inevitável, um 'não há dia' que se confunde com um 'há dia', sua aparição coincidindo com o momento em que ele ainda não apareceu. $O$ dia, nos cursos do dia, nos permite escapar às coisas, ele nos faz compreendê-las e, fazendo-nos compreendê-las, ele as torna transparentes e como que nulas; - mas o dia é isto a que não se escapa : nele nós somos livres, mas ele mesmo é fatalidade, e o dia como fatalidade é o ser do que há antes do dia, a existência de que é necessário desviar-se para falar e para compreender."
} 
respeito também a sua relação com a fenomenologia, não somente a fenomenologia tratada topicamente em seu texto, mas o que há de crítica fenomenológica em seus escritos. O de Marlène Zarader é um exemplo recente (há outros, como o livro de Thomas Carl Wall, que buscam análises semelhantes). ${ }^{33} \mathrm{~A}$ autora explora algumas das possíveis leituras fenomenológicas da obra de Blanchot, e busca demonstrar que nunca se trata somente, em sua ficção ou em sua ensaística, de uma descrição do fenômeno do Neutro, do Fora ou da Literatura, mas também a tentativa de mostrar como esses eventos impossibilitam sua reinscrição sob a própria noção de horizonte. O "dado" que aparece do mundo e do horizonte, na obra, é para Blanchot seu próprio "éclatement", uma experiência - se é que continua sendo uma experiência, sendo o resíduo (a cinza), de certa forma, de toda relação com a experiência - de sua própria impossibilidade. Trata-se de procurar pensar, uma vez e sempre, qual o papel da literatura em pensar esse evento do fora do horizonte do mundo. Como diz Blanchot em Le Livre à Venir, "mais decisiva que o dilaceramento dos mundos, é a exigência que rejeita o próprio horizonte de um mundo" ${ }^{34}$.

Não somente nos ensaios recolhidos em La Part du Feu, como pode-se notar acima, mas também em L'Espace Littéraire, e no Le Livre à Venir, toda a literatura e crítica de Blanchot é um esboço das formas possíveis de acesso à esta experiência liminar, evidência essa que buscaremos em alguns textos exemplares de sua ficção; Esse esforço se acentua em seus escritos literários, mas sua crítica não cessou nunca de buscar esse lugar limítrofe, a que se deu diversos nomes: neutro; literatura; obra; desastre. A sucessão dos nomes dissimula, talvez, a dificuldade de acesso de cada um desses fenômenos, se podemos ainda chamá-los assim. Poderíamos dizer que se trata sempre da mesma "experiência-limite", termo que Blanchot utiliza ao analisar alguns aspectos da obra de Georges Bataille em L'Entretien Infini, se a sucessão dos nomes não mostrasse precisamente que os termos, ainda que somente indicativos, não bastam para dar conta do que

\footnotetext{
${ }^{33}$ Referimo-nos a L'Être et le Neutre: à partir de Maurice Blanchot. A autora explora as relações de Maurice Blanchot com a noção de horizonte. Dele extraímos a seguinte passagem, se referindo à postura "fenomenológica" da obra de Blanchot: "(...) o dado fenomenológico é outro: o que aparece do mundo, é seu explodir, e isso que é vivido no curso desta experiência é sua impossibilidade. É um tal dado que Blanchot se emprega a descrever. E é em perfeita conformidade com a experiência na qual ele se dá que ele a nomeia : o Fora. Essa experiência, com efeito, não se situa no mundo (o que reconhecia Maldiney), e ela tampouco abre um outro mundo (em todo caso, nada nela permite afirmálo), ela designa sobretudo o outro de todo mundo: o que Yves Bonnefoy nomeava (para dele se desviar) 'o reverso inabitável do mundo'. É porque ela é votada a desdobrar-se fora do mundo que ela pode e deve ser dita 'fora'." (ZARADER, 2001, p. 105-106)

${ }^{34}$ BLANCHOT, Maurice. Le Livre à Venir. Paris: Gallimard, 1999, p. 278.
} 
pretendem indicar. Como se na experiência limite a negação dialética da atualidade cessasse de operar; e o que o mesmo Bataille denominou "excesso do trabalho", trabalho responsável por erguer o mundo do sentido, se tornasse assim o excedente sempre presente e ausente, inacessível à apropriação do próprio trabalho.

Os procedimentos textuais utilizados por Blanchot são muito variados, mas alguns exemplos podem ser dados, e definitivamente merece destaque o que Evelyne Grossman apontou em ensaio recolhido no volume L'Angoisse à Penser: o uso que Blanchot faz dos anagramas. De maneira análoga à de Saussure em seus Anagramas, Grossman busca no texto de Blanchot (em especial em Thomas l'Obscur) a repetição de sílabas e letras, a ida e vinda de sílabas e letras, jogo que fica muito claro em certos momentos dos récits e romances de Blanchot. Podemos estender esse argumento e dizer que em Blanchot a concepção da própria escritura é anagramática, a escritura é entendida enquanto retorno sempre possível do anagrama: nela as palavras são antecipadas, adiadas, retomadas, suspendidas, tornando o movimento do texto (que, como foi mencionado, já opera no registro do estranho, do insólito, do abscôndito) um movimento de vai e vem, de relação e derrelição, de idas e voltas, e não somente ao nível da narrativa como um todo, mas ao nível das sílabas, das letras, ao nível dos fragmentos indetermináveis de palavras (e este é um dos sentidos em que se pode afirmar que a escritura de Blanchot é fragmentária). A questão que jamais é deixada de lado, tanto na ensaística como na ficção, é se há uma linguagem que possa agir sem edificar, sem participar da constante retomada da realização do mundo do dia.

Não se poderia deixar de lado, em uma análise da questão do limite na obra de Blanchot, a função que a imagem desempenha em seus textos, tentativa dos capítulos que seguem. A imagem é esse âmbito que apresenta uma dimensão ontológica irredutível à significação e à verdade. Pois existem duas dimensões do imaginário para Blanchot, antevistas já no título de um dos apêndices de L'Espace Littéraire (intitulado "As duas versões do imaginário"): há a imagem enquanto imitação de um modelo disponível de antemão, a imagem enquanto mimese, repetição bem ou mal sucedida de algo que lhe é anterior; e há a noção de imagem explorada pela literatura, a imagem enquanto o próprio movimento da alusão e da analogia. Nesse domínio, a imagem se relaciona à fascinação: distintamente de quem vê, isto é, quem domina a distância, o sujeito ainda receptáculo do poder de definição das distâncias, de cada elemento do horizonte, capaz de evitar confundir- 
se com as coisas que vê, a imagem enquanto fascinação remete a um outro tipo de visão. No caso de quem sofre a atração da imagem, o ver é entrar em contato, é confundir-se com a coisa. Levados pela força da imagem, perdemos a capacidade de dotar toda experiência de um sentido, isto é, de doar-lhe um limite. A imagem faz o mundo recuar, se afirmando em uma presença constituída de ausência, uma presença estranha à toda presença temporal ou espacial. Uma vez atingida pelo fascínio - pela "paixão da imagem" - a visão se confunde com o visto. Perdido o foco do olhar, a visão não é mais entendida como a possibilidade de ver, mas sim como "impossibilidade de não ver".

Como no récit - é essa uma das faces da Folie du Jour, mas também dos outros textos que vamos analisar -, quem se encontra sob o domínio da fascínio não percebe objeto algum, não vê nada senão o "meio indeterminado da fascinação", meio absoluto em que os limites são destroçados pela profundidade sem limites da própria imagem, "absolutamente presente embora não dada", em que os objetos afundam, deslizam para o horizonte indeterminado e absoluto da imagem. Não se delimita mais um começo e um fim do horizonte, um começo e um fim da atração, quando é do imaginário que se trata. A imagem, no domínio do imaginário, não é mais o que alude a outra coisa, mas, como foi dito, o próprio movimento infinito da alusão. E a literatura - a escritura - é a entrada no abismo da fascinação, no domínio do imaginário. É deixar que a linguagem seja arrebatada pelo fascínio, pelo que Blanchot chamou de "ouverture opaque et vide sur ce qui est quand il n'y a plus de monde, quand il n'y a pas encore de monde". A obra de Blanchot é um catálogo dessas pequenas lacunas, desses orifícios pelos quais vazam ser e sentido, a abertura em fuga do mundo, figuradas na cena, recorrente em Blanchot, de um olho aberto sobre si mesmo, que se repete nos três textos que analisaremos. Em Thomas l'Obscur temos o primeiro exemplo citado à exaustão dessa visão opaca, voltada sobre si mesma.

Les mots, issus d'un livre qui prenait une puissance mortelle, exerçaient sur le regard qui les touchait un attrait doux et paisible. chacun d'eux, comme un œil à demi fermé, laissait entrer le regard trop vif qu'en d'autres circonstances il n'eût pas souffert [...] II se voyait avec plaisir dans cet œil qui le voyait. Son plaisir même devint très grand. II devint si grand, si impitoyable qu'il le subit avec une sorte d'effroi et que, s'étant dressé, moment insupportable, sans recevoir de son interlocuteur un signe complice, il aperçut toute l'étrangeté qu'il y avait à être observé par un mot comme par un être vivant, et non seulement un mot, mais tous les mots qui se trouvaient 
dans ce mot, par tous ceux qui l'accompagnaient et qui à leur tour contenaient eux-mêmes d'autres mots, comme une suite d'anges s'ouvrant à l'infini jusqu'à l'œil de absolu. (BLANCHOT, 1950, p. 2728) ${ }^{35}$

A própria linguagem poética é redefinida, por Blanchot, em uma das notas mais importantes do Espace Littéraire, não como a linguagem figurativa, comparativa, metafórica e metonímica, mas a linguagem que não produz imagem, que não figura. Não signos, mas "imagens, imagens de palavras e palavras em que as coisas se fazem imagens". No mundo do dia, as coisas, os entes são transformados em objetos, de modo que se estabelece entre elas uma divisão clara, garantindo a continuidade do espaço, mantendo as distâncias conhecidas em seu lugar e garantindo, através do privilégio de certos aspectos da ficção, uma estadia. No imaginário as coisas são levadas à aporia de sua aparição, e é nessa interrupção do circuito do mundo - que, de certa forma, era já a concepção heideggeriana da obra de arte ${ }^{36}$, sempre presente nos escritos de Blanchot, ainda que de forma negativa - é que inopera a literatura, retirando-nos o abrigo possível do mundo, sacudindo mesmo o limite entre o sujeito e o mundo e marcando a descontinuidade entre a palavra e o mundo, sulcando no seio do mundo a profundidade ilimitada da imagem, imagem essa que, diferentemente do signo, não significa, não acena, não desvenda, não alude, ou deixa plenos de intransitividade todos esses verbos, não restando senão o movimento metonímico da alusão. Não o além, mas o aquém do mundo, a sua eterna iminência.

Uma literatura que se detém na soleira do mundo, que busca na linguagem os artifícios e a potência capaz de interromper as realizações da própria linguagem, "o sol situado eternamente abaixo do horizonte, a mancha cega que o olhar ignora, ilhota de ausência no seio da visão", é o que Blanchot procurou insistentemente ao longo de toda sua obra. Pois a palavra, em Blanchot, e é isso que deveria ter ficado evidente, talvez, nesse capítulo, sempre já deslizou - o que torna a narrativa,

\footnotetext{
35 "As palavras, saídas de um livro que tomava uma potência mortal, exerciam sobre o olhar que as tocava uma atração doce e pacífica. Cada uma delas, como um olho semicerrado, deixava entrar o olhar demasiado vivo que em outras circunstâncias não teria sofrido (...) Ele se via com prazer neste olho que o via. Seu prazer mesmo tornou-se muito grande. Tornou-se tão grande, tão implacável, que ele o sofreu com uma sorte de temor e que, opondo-se, momento insuportável, sem receber de seu interlocutor um sinal cúmplice, ele percebeu toda a estranheza que havia em ser observado por uma palavra como por um ser vivo, e não somente uma palavra, mas todas as palavras que se encontravam nessa palavra, por todas essas que a acompanhavam e que por sua vez continham elas mesmas outras palavras, como uma série de anjos se abrindo ao infinito até o olho do absoluto."

${ }^{36}$ HEIDEGGER, Martin. A Origem da Obra de Arte. Lisboa: Edições 70, 2005.
} 
sempre, a narrativa de um interlúdio, em que o prelúdio era já o reinício do relato, o lugar em que esse "acontecimento ainda por vir" do próprio relato é chamado a realizar-se. Veremos de que modo isso acontece nos capítulos a seguir. 


\section{Capítulo III - Thomas l'Obscur e a questão do sentido}


Thomas l'Obscur, o primeiro romance de Blanchot, foi publicado em 1941, e em versão condensada em 1950, quando Blanchot se desloca do roman ao récit, diluindo ainda mais os já exíguos acontecimentos de suas ficções. Já nele encontramos algumas estruturas e episódios "em abismo" e as preocupações estruturais de configuração que perpassam todos seus romances e récits ${ }^{37}$. Se a riqueza episódica das ficções de Blanchot parece mínima, e é, a riqueza desses episódios desmente o leitor mais afoito ${ }^{38}$. Alguns dos poucos e bons exemplos de leituras pacientes da obra de Blanchot podem ser encontrados em Jean Starobinski e Jacques Derrida, o segundo inclusive tendo feito do livro em questão objeto de um dos seminários ministrados em 1976-1977 ${ }^{39}$. São, entre as poucas coisas escritas sobre a ficção de Blanchot, as inspirações do presente capítulo. Aproximando-nos do texto, deve-se mencionar o jogo do título, em que reverbera já toda a literatura blanchotiana; o título, assim como qualquer espécie de paratexto ou semelhante, é crucial para Blanchot, e será o locus de grande parte de sua literatura e dos efeitos que ela exerce. "Thomas", como bem salientou parte da crítica, foi o nome escolhido

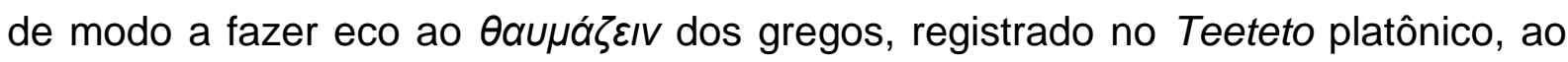
espanto que é a origem de toda sabedoria e de todo pensamento (e em Blanchot podemos estender esse espanto, certamente, à obra de arte, ao menos a certa noção da obra de arte). O título, portanto, ecoa talvez tarefa mais nobre para a literatura do que a de relato, testemunho, ou Bildung do ego: também a literatura

\footnotetext{
${ }^{37}$ Buscaremos nos ater à segunda versão do texto, mais própria para o estudo das estruturas que nos propomos no presente trabalho. As passagens que comentaremos, grosso modo, são mantidas em ambas as versões.

38 "As duas primeiras novelas de Blanchot - Thomas l'Obscur (1941) e Aminadab (1942) - estão discutivelmente entre algumas dos mais cativantes, ainda que obscuros, textos literários modernos. Mais de cinquenta anos após sua publicação, sua resistência à interpretação permanece a mesma. Essa inexcrutabilidade, entretanto, não é meramente o produto de fatores contextuais não familiares, nem deriva simplesmente de uma sonegação sistemática de informação pelo autor ou narrador. De fato, contrariamente à sua reputação, essas primeiras novelas de Blanchot não são nem plenas de alusões esotéricas nem obcecadas com o silêncio; elas são, sobretudo, escandalosamente tagaleras e auto-explicativas, e dadas à digressões infindas designadas a elucidar o propósito das estórias que elas contam. Nesse processo, de toda forma, cada um desses textos revela ser mais do que a soma de suas partes, com o resultado de que o que é mais enigmático é a extensão em que, ao passo que se lê, os mistérios locais e específicos postos pela escrita de Blanchot abrem caminho para o mais amplo, mais intratável problema da natureza do discurso que de alguma maneira os engendrou. $\mathrm{O}$ único segredo desses textos, poderia-se dizer, é o segredo de sua própria possibilidade; e a principal questão que eles levantam, portanto, é a questão de sua fundação enquanto obras de literatura." (HILL, p. 53)

39 Seminário ainda inédito, intitulado "Blanchot - Thomas l'Obscur", de oito sessões, que deu sequência a um seminário intitulado "La Chose - Heidegger/Blanchot", de seis sessões de duração. Ambos foram ministrados em Yale e na École Normale Supérieure, e ambos são ainda inéditos, embora existam planos para publicação. Algumas das notas desses seminários foram publicadas sob forma e ensaios no volume Parages, de 1986, com edição aumentada em 2003.
} 
começa no espanto. Espanto que ganha contornos ainda mais abissais com o uso sequencial do epíteto "l'obscur", que, como é sabido, é o epíteto tradicional dado ao filósofo pré-socrático Heráclito, senhor do fragmento, tido como obscuro por conta de suas sentenças herméticas e lacunares. Assim se inicia o relato, no primeiro capítulo, entre os mais densos do récit:

Thomas s'assit et regarda la mer. Pendant quelque temps il resta immobile, comme s'il était venu là pour suivre les mouvements des autres nageurs et, bien que la brume l'empechât de voir très loin, il demeura, avec obstination, les yeux fixés sur ces corps qui flottaient difficilement. Puis, une vague plus forte l'ayant touché, il descendit à son tour sur la pente de sable et glissa au milieu des remous qui le submergèrent aussitôt. La mer était tranquille et Thomas avait l'habitude de nager longtemps sans fatigue. Mais aujourd'jui il avait choisi un itinéraire nouveau. La brume cachait le rivage.(...) (BLANCHOT, 2007, p.9) ${ }^{40}$

Thomas chega a uma margem, e se senta para ver o mar, antes de nadar e sofrer toda sorte de transformações. Como bem apontou Jean Starobinski ${ }^{41}$, a narrativa começa com Thomas se lançando à natação - e a suas transformações de um ponto do rio, e termina com Thomas chegando a outro ponto do rio, havendo, portanto, algo como um padrão circular na estrutura do romance/récit. Thomas fita o horizonte e o mar. Nada mais nos é dito acerca do personagem. O leitor se limita a perscrutar Thomas, de que nada sabe sobre o passado ou intenções. Há somente alguém, de que nada sabemos sobre o passado, que chega à margem - e como apontaram diversos estudiosos, e as margens e limites são sempre a questão seminal para Blanchot - e fita o horizonte. Não há fixação nem de que ponto da margem, nem de que ponto no horizonte, tampouco qualquer coordenada temporal ou espacial que permita ao leitor situar-se, de modo que possa fixar melhor as características do protagonista. E não só ao leitor, como também aos personagens de Blanchot falta qualquer certeza, qualquer átimo de contexto, qualquer fragmento de referência que pudesse tornar a situação menos obscura. No entanto, especial atenção deve ser dada ao incipit e aos títulos dos romances e récits de Blanchot, pois muitas vezes enunciam toda a questão que contêm. Essa é, aliás, uma das

\footnotetext{
40 "Thomas se sentou e olhou para o mar. Durante algum tempo permaneceu imóvel, como se tivesse vindo ali para seguir os movimentos dos outros nadadores e, ainda que a bruma o impedisse de ver muito longe, ele permaneceu, com obstinação, os olhos fixos sobre esses corpos que flutuavam com dificuldade. Então, uma vaga mais forte o havendo tocado, desceu por sua vez sobre a duna e deslizou para o meio dos redemoinhos que rapidamente o submergiram. $\mathrm{O}$ mar estava tranquilo e Thomas tinha o hábito de nadar por muito tempo sem fadiga. Mas hoje ele havia escolhido um itinerário novo. A bruma escondia a margem."

${ }^{41}$ Revue Critique, Nr. 229. "Thomas l'Obscur, chapitre premier", p. 498.
} 
teses do presente texto: o que em outras paragens é chamado de paratexto ${ }^{42}$, especialmente no sentido do peritexto (título, subtítulo, intertítulo, nomes de autor e editor, datas, prefácios, notas, ilustrações, índices, prefácios e posfácios, orelhas) na definição de Gérard Genette que tornou o termo conhecido - em Blanchot constitui-se no locus privilegiado da literatura, no locus preferencial do que seria a "escritura": na escritura ficcional, e esse termo se estende, talvez, à toda a escrita de Blanchot no que diz respeito aos títulos, todos esses elementos são lugares onde acontece certo deslocamento, proposital ou não, de certos lugares-comuns da literatura e da crítica. Postura essa que seria posteriormente e com grande proveito empregada por Jacques Derrida. Em Blanchot, como buscaremos fazer notar, é nesses lugares liminares, onde se anuncia um título, um início, um fim, um prefácio, que se enuncia de forma privilegiada a questão da literatura. Mas voltemos ao texto em questão. Da primeira versão à segunda, como bem notou, entre outros, o mesmo Jean Starobinski, a diferença é circunstancial: Blanchot suprime uma série de imagens em que o Thomas se depara somente com o desencontro e a errância, até restar somente a figura solitária de Thomas se deparando com os elementos, com a imanência, na figura do mar. Diversas passagens da literatura - e aqui certamente o eco particular de Mallarmé e do naufrágio do Un coup de dés se faz a um só tempo ausente e presente - evocam paisagens marinhas. Podemos enumerar, algo ao acaso, os naufrágios bíblicos, o cemitério marinho de Valéry, diversos poemas de Mallarmé - a menção a um barco vazio que surge no horizonte, recortada da segunda versão, evoca, certamente, algo que Blanchot escreveria alguns anos depois, quanto à especificidade do espaço da ficção, e certamente também de sua própria escrita ficcional, em um ensaio recolhido em Le livre à venir:

Un coup de dès est l'affirmation sensible de ce nouvel espace. II est cet espace devenu poème. La fiction qui y est à l'oeuvre, ne semble avoir d'autre visée - par l'épreuve du naufrage d'où naissent et où s'exténuent des figures de plus en plus subtilement allusives à des espaces toujours plus lointains - que de parvenir à la dissolution de toute étendue réelle, à 'la neutralité identique du gouffre', avec quoi, au point extrême de la dispersion, ne s'affirme plus que le lieu: le rien comme le lieu où rien n'a lieu. Est-ce alors l'éternel néant qu'Igitur cherchait à atteindre? Une pure et définitive vacance? Non pas, mais un remuement indéfini d'absence l'inférieur clapotis quelconque', les 'parages du vague en quoi toute réalité se dissout', sans que cette dissolution puisse jamais dissoudre le mouvement de cette

${ }^{42}$ GENETTE, Gérard. Seuils. Seuil, coll. "Poétique”, Paris, 1987. 
dissolution devenir incessamment en devenir dans la profondeur du lieu. (BLANCHOT, 2007, p. 322) ${ }^{43}$

Necessário mencionar essas imagens ao analisar a paisagem marinha de Thomas l'obscur, ao menos de modo a compreender o uso dessas imagens no quadro geral da obra ficcional de Blanchot. O livro é o relato de uma partida. Thomas chega - de outra jornada? não se sabe de onde ou por que - e senta-se, perscruta o mar. Lança-se ao mar e começa a nadar. O esforço da passagem - e dos episódios exíguos de qualquer acontecimento pelos quais passará o herói - diz respeito à tentativa de fazer unir a morte e o morrer, assim como grande parte da obra de Blanchot, tentativa que se mostrará infrutífera, como veremos. A primeira referência que assalta o leitor que conhece algo da obra crítica de Blanchot é a relação da obra com o mito clássico de Orfeu, que desce aos infernos em busca de sua amada, Eurídice. Pois Thomas desce a um inferno, em certa medida, em busca de Anne, que ocupa o espaço narrativo, poderíamos dizer, de sua "amada". E então Thomas passa por uma série de experiências-limite, tal qual o escritor que busca constituir-se através da obra que constitui. Para analisar essa analogia, que será nosso ponto de partida no presente capítulo, é necessário retornar ao livro em que está presente a principal releitura mitológica de Blanchot, L'espace littéraire, ao capítulo intitulado "Le regard d'Orphée", no qual Blanchot registrou sua leitura particularíssima do mito órfico. Basta por hora assinalar que a sequência de experiências sempre termina com Thomas encontrando a inexorabilidade do il y a, o "dia que há por trás do dia, quando se pensava o dia findo", como ele diz em outras paragens. É nisso, talvez, que a narrativa permanece visceralmente moderna, como notou Kevin Fitzgerald em The Negative Eschatology of Maurice Blanchot, um dos poucos textos que ensaiam uma leitura integral do primeiro livro de Blanchot (a maioria se limita a capítulos ou sessões, como Jean Starobinski, que analisou somente o primeiro capítulo da versão em roman, ou Thomas Schestag, que analisou somente o quarto capítulo):

\footnotetext{
43 "Um lance de dados é a afirmação sensível desse novo espaço. É esse espaço transformado em poema. A ficção que nele se opera não parece ter outro objetivo - pela experiência do naufrágio, do qual nascem e no qual se extenuam figuras cada vez mais sutilmente alusivas a espaços sempre mais longínquos - senão chegar à dissolução de toda extensão real, à "neutralidade idêntica do abismo" com a qual, no ponto extremo da dispersão, nada mais se afirma exceto o lugar: o nada como o lugar onde nada tem lugar. Será então o eterno nada que Igitur procurava atingir? Uma pura e definitiva vacância? Não, mas bulício indefinido de ausência, o "inferior marulho qualquer", as "paragens do vago onde toda realidade se dissolve", sem que essa dissolução possa jamais dissolver o movimento dessa dissolução, devir incessantemente por vir na profundeza do lugar." (BLANCHOT, 2005, p. 348)
} 
Despite the fact that the text aligns itself with the tradition of the conte philosophique (philosophical novel), a tradition that dates back at least to Voltaire's Candide, Thomas the Obscure remains utterly modern. Like the anfractuous sculpture of Robert Smithson or the spiral gyre of Yeats, the novel's form possesses both circular and linear characteristics. Indeed, influenced by Mallarmé's Un Coup de dés, Blanchot's novel disperses its narrative in a manner that, as it staggers or telescopes events over several sections, whips all attempts at linear interpretation into a whirlpool. Moreover, similar to Blanchot's The Infinite Conversation, which begins and ends with explications addressing the Absence of the Book, Thomas the Obscure forwards a form that, like the rondel, traps the reader in the paradoxical insularity of infinitude, for it begins and concludes with Thomas encountering the briny abyss. This circular form, lacking both beginning and end, cannot help but shipwreck the reader accustomed to linear narratives in the spiraling perdition of the tourbillon. ${ }^{44}$

É essa estrutura, circular e linear a um só tempo, que buscaremos analisar. A semelhança que mencionamos, com o Un Coup de dés, também é assinalada por diversos outros intérpretes; analisá-la-emos oportunamente. Importa dizer no momento que a narrativa de Blanchot é constituída por movimentos telescópicos, por closes de movimentos que não se entrelaçam em um todo contínuo, de forma sistemática. Podemos citar, um pouco ao acaso, as estruturas em abismo presentes tanto em Thomas l'obscur como em Aminadab e La folie du jour, que serão objeto do presente trabalho. Thomas "l'obscur", ou simplesmente Thomas, insinua imageticamente, em mise en abyme, a experiência da escritura e da leitura. Por enquanto basta dizer isso quanto às possíveis filiações "modernas" do livro. Mas retornemos ao início da narrativa, quando Thomas senta-se e perscruta o mar. É, então, um olhar resoluto, um olhar constituído, que discerne entre as distâncias e distribui os quadrantes. A inteireza, a constituição ideal desse corpo que sustenta esse olhar é fundamental na compreensão dessa primeira sessão do livro. Então Thomas, corpo e olhar sólidos, decide nadar - o elemento líquido é importante nas obras ficcionais de Blanchot, assim como em seus devaneios filosóficos - e encontra na água, repetidas vezes, o estranhamento em elementos que passam a the soar

\footnotetext{
44 "A despeito do fato de que o texto se alinhe à tradição do conte philosophique (conto filosófico), uma tradição que data ao menos do Cândido de Voltaire, Thomas l'Obscur permanece visceralmente moderno. Como a escultura tortuosa de Robert Smithson ou o spiral gyre de Yeats, o formato da novela possui características tanto circulares como lineares. Com efeito, a novela de Blanchot, influenciada por Un coup de dès, dispersa sua narrativa de uma maneira que, ao passo que escalona ou condensa eventos ao longo de diversas seções, transforma todas as tentativas de interpretação linear em um turbilhão. Além disso, de modo similar a L'Entretien infini, que começa e termina com explicações abordando a Ausência do Livro, Thomas l'Obscur traz à baila uma forma que, como o rondel, aprisiona o leitor na insularidade paradoxal da infinitude, porque se inicia e conclui com Thomas encontrando o abismo salobro. Essa forma circular, à qual faltam ambos início e fim, não pode senão naufragar o leitor acostumado à narrativas lineares na perdição helicoidal do tourbillon." Trecho retirado de The Negative Eschatology of Maurice Blanchot. O texto está disponível somente para acesso online.
} 
desconhecidos. Nadando, Thomas passa a ter certeza que mesmo a pele the faltava; percebe, então, que "contemplava o vazio na intenção de nele encontrar alguma segurança". Então o mar soergue, vem a tempestade, que "dispersava o mar em lugares inacessíveis". Mas em Blanchot a insegurança do movimento vem sempre já desfeita: "as espumas bagunçavam o céu e, ao mesmo tempo, havia um silêncio e uma calma que deixavam pensar que tudo já estava destruído." Mesmo a certeza de estar em meio à água falta a Thomas. Sente a ausência de água invadir seu corpo, a água "o entranha violentamente". A fadiga termina por levar seus membros, e até o uso do corpo traz consigo a mesma estranheza proporcionada pela água. Thomas, em seu devaneio, se confunde com o mar. É tratado, mais de uma vez, como um "bateau à la dérive", e nada, insiste em nadar. Thomas sofre então uma primeira metamorfose, tornando-se o que Blanchot chama de "monstro privado de nadadeiras". A descrição, embora sem floreios - ao menos no récit de 1950, cuja diferença em relação ao roman de 1941 é ser despido de quaisquer hipérboles e alegorias desnecessárias - termina com a seguinte passagem, crucial, como foi notado pelos exíguos intérpretes dessa narrativa:

La tentation prit un caractère tout à fait insolite, lorsque de la goutte d'eau il chercha à se glisser dans une région vague et pourtant infiniment précise, quelque chose comme un lieu sacré, à lui-même si bien approprié qu'il lui suffisait d'être là, pour être; c'était comme un creux imaginaire où il s'enfonçait parce qu'avant qu'il y fût, son empreinte y était déjà marquée. II fit donc un dernier effort pour s'engager totalement. Cela fut facile, il ne rencontrait aucun obstacle, il se rejoignait, il se confondait avec soi en s'installant dans ce lieu où nul autre ne pouvait pénétrer." (BLANCHOT, 2007, p. 12) ${ }^{45}$

Thomas - de que, como mencionamos, uma das imagens é a do escritor, sobre quem temos que esclarecer algumas coisas quando se trata de Blanchot busca, portanto, ao longo desse primeiro e importante capítulo do livro, de algo como um porto seguro, um "oco imaginário", um "lugar sagrado" onde the baste lá estar para ser, um lugar, ficcional, em que as diretrizes e configurações do ser já estejam dispostas, onde nada, nenhum outro possa penetrar. Esse é o lugar da completude de Thomas, que arriscamos aqui, faz referência clara à totalidade do testemunho da escrita sendo recoberta plenamente pela totalidade do testemunho

\footnotetext{
45 "A tentação tomou um caráter absolutamente insólito, quando da gota d'água ele tentou se deslizar em uma região vaga e no entanto infinitamente precisa, algo como um lugar sagrado, a ele mesmo tão apropriado que bastaria estar lá para ser; era como um oco imaginário onde ele se enfiava porque antes que ele o fosse, sua impressão já estava aí marcada. Fez então um último esforço para se engajar totalmente. Isso foi fácil, não encontrava nenhum obstáculo, ele se reencontrava, ele se confundia consigo ao se instalar nesse lugar em que nenhum outro podia penetrar."
} 
visual ou ideal, ao preenchimento sem adumbramento: ontologia do ser unívoco a que corresponde toda uma metafísica do testemunho. É nesse momento que Thomas volta a si, ainda que com uma curiosa sensação de queimação nos olhos, e busca orientar-se diante da situação. Vê um nadador perdido à meia água, entre a linha inconstante do horizonte. Fica algum tempo a observar, em algo como um exercício da paciência. Sente uma liberdade tão grande nessa sensação que essa liberdade acaba por tornar-se uma dor. Assim se conclui o primeiro capítulo: com Thomas tentando constituir-se em constituindo sua totalidade, curvando, talvez, as costas ao infinito do glissement, ao infinito deslocamento do sentido, potencializado pela descrição do mar, da água, dos naufrágios, que é ainda mais episódica e prolixa na versão em romance do texto. Não somente as paisagens marinhas, os naufrágios, como mencionamos, mas a água é um dos elementos centrais na ontologia particular da obra literária de Blanchot, como leituras já antigas de sua obra atestaram ${ }^{46}$. Thomas então se dirige a um pequeno bosque. $\mathrm{O}$ dia está por acabar, mas ainda é possível discernir "certos detalhes da paisagem e, em particular, a colina que limitava o horizonte e que brilhava, descuidada e livre." O horizonte, certo horizonte de sentido, ao menos, se mantém; é possível discernir, ainda, entre os limites. Assim começa o segundo capítulo do livro. Então Thomas retorna, indeciso, no segundo capítulo. Tudo que faz - se é que chega a fazê-lo - é assombrado por um sentimento obscuro de dúvida. Quase como se o cogito cartesiano, a certeza indubitável do ser não chegasse a assumir em Thomas um formato final; como se a repetição fosse sua única possibilidade de ser, sua prisão, sua ontologia. "À la vérité, il y avait dans sa façon d'être une indécision qui laissait un doute sur ce qu'il faisait." William S. Allen notou, em três longos ensaios entre os mais importantes para a compreensão da obra ficcional de Blanchot, que em Thomas l'Obscur a questão ainda é a da impossibilidade da constituição de um personagem, questão que será transformada, em Aminadab, na questão da impossibilidade da constituição da imagem - e do próprio personagem enquanto dependente do estatuto da imagem - o que foi chamado por parte da crítica de "profundidade deslizante" da imagem, questão que investigaremos nos capítulos

\footnotetext{
${ }^{46}$ Fazemos aqui referência aqui ao livro de Françoise Collin, uma das primeiras teses acadêmicas a surgir em língua francesa sobre sua obra, Maurice Blanchot et la question de l'écriture, de 1973, o primeiro, inclusive, a tratar exclusivamente de sua obra - de que se tem notícia. Lá são esclarecidas as relações entre certa noção barroca da dobra e da imagem da água em Blanchot: "A imagem da água que no limiar da obra blanchotiana assombra Thomas l'Obscur... é talvez indicativa: dobras incessantes, desdobras, redobras que apagam-se reciprocamente." (p. 194).
} 
seguintes, nesse e em outros textos. Então Thomas, após entrar em um lugar de espaço ambíguo, ao mesmo tempo extremamente pequeno e extremamente vasto, se encontra com a noite.

\begin{abstract}
(...) A cet instant, Thomas commit l'imprudence de jeter un regard autour de lui. La nuit était plus sombre et plus pénible qu'il ne pouvait s'y attendre. L'obscurité submergeait tout, il n'y avait aucun espoir d'en traverser les ombres, mais on en atteignait la réalité dans une relation dont l'intimité était bouleversante. Sa première observation fut qu'il pouvait encore se servir de son corps, en particulier de ses yeux; ce n'était pas qu'il vît quelque chose, mais ce qu'il regardait, à la longue le mettait en rapport avec une masse nocturne qu'il percevait vaguement comme étant lui-même et dans laquelle il baignait. Naturellement, il ne formula cette remarque qu'à titre d'hypothèse, comme une vue qui était commode, mais à laquelle seule la nécessité de démêler des circonstances nouvelles l'obligeait à recourir. Comme il n'avait aucun moyen pour mesurer le temps, il attendit probablement des heures avant d'accepter cette façon de voir, mais, pour luimême, ce fut comme si la crainte l'avait emporté tout de suite, et c'est avec un sentiment de honte qu'il leva la tête en accueillant l'idée qu'il avait caressée : en dehors de lui se trouvait quelque chose de semblable à sa propre pensée que son regard ou sa main pourrait toucher. Rêverie répugnante. Bientôt, la nuit lui parut plus sombre, plus terrible que n'importe quelle nuit, comme si elle était réellement sortie d'une blessure de la pensée qui ne se pensait plus, de la pensée prise ironiquement comme objet par autre chose que la pensée. C'était la nuit même. (BLANCHOT, 2007, p. 17) ${ }^{47}$
\end{abstract}

Thomas, curiosamente, encontra-se com uma noite mais obscura, mais penosa do que de costume, uma noite que ninguém tem a esperança de atravessar, a noite de todas as outras noites. Mas Thomas ainda aguarda algo que se assemelhe à realidade. Nota, então, que não pode contar com seus olhos, com o artifício das lentes, do olho que observa e estabelece os nexos. Percebe, então, que o que perscruta é uma massa obscura e disforme, que descobriremos, a seguir, tratar-se do próprio pensamento de Thomas, materializado nessa confusa e obscura matéria, da qual ele próprio sente fazer parte. A noite torna-se, então, mais sombria

\footnotetext{
47 "Nesse instante, Thomas cometeu a imprudência de lançar um olhar em torno de si. A noite era mais escura e mais penosa que ele poderia dela esperar. A obscuridade submergia a tudo, ele não tinha nenhuma esperança de atravessar-lhe as sombras, mas atingia-se a realidade em uma relação cuja intimidade era chocante. Sua primeira observação foi que ele não podia ainda servir-se de seu corpo, em particular de seus olhos; isso não era porque visse alguma coisa, mas isso que ele via com o tempo o punha em contato com uma massa noturna que ele percebia vagamente, como sendo ele mesmo, e na qual ele se banhava. Naturalmente, não formulou essa observação senão a título de hipótese, como uma visão que era cômoda, mas à qual a necessidade somente de desemaranhar circunstâncias novas o obrigava a recorrer. Como não possuía nenhum meio para mesurar o tempo, esperou provavelmente horas antes de aceitar esta maneira de ver, mas, para ele mesmo, isso foi como se o temor o houvesse arrebatado de imediato, e foi com um sentimento de vergonha que ergueu a cabeça ao acolher a ideia que o havia acariciado: fora dele se encontrava algo similar a seu próprio pensamento, que seu olhar ou sua mão poderiam tocar. Devaneio repugnante. Logo a noite pareceu mais escura, mais terrível que não importa qual noite, como se ela houvesse realmente saído de uma ferida do pensamento que não se pensava mais, do pensamento tomado ironicamente como objeto por outra coisa que não o pensamento."
} 
ainda, "mais terrível que não importa qual noite", "(...) como se saída de uma ferida do pensamento. Era a noite ela mesma."

Essa noite, chamada em outras partes da obra de Blanchot - pensamos aqui, em especial, nos ensaios recolhidos em L'Espace Littéraire - de "a outra noite" remete, pensamos, e conosco alguns outros intérpretes da obra de Blanchot, tratarse do excedente da morte, o excedente não-apropriável da morte (e, na hipótese que aventamos aqui, com outros autores ${ }^{48}$, do sentido), que Blanchot leu também na obra de Georges Bataille, em especial no ensaio sobre a noção de despesa, diferentemente da morte-negatividade da filosofia, em especial a lecionada nas leituras que Alexandre Kojève efetuou da noção de negatividade na obra de Hegel. Aqui não se trata, de fato, da morte, mas da impossibilidade da morte, como Blanchot dirá em tantos ensaios. Impossibilidade justamente de uma apropriação da morte, de um transformar sua negatividade em positividade, seu acontecer em fato. A morte, em Blanchot, é a do Caçador Graccus de Kafka, que vaga de cidade em cidade e não consegue findar. Notamos também, ainda que de forma incipiente, uma certa questão da visão em Blanchot, que se repetirá ao longo de sua obra. As imagens, nos diz Blanchot, inundavam a existência inteira de Thomas, impedindo-o de ver coisa que fosse e, pior ainda, tornando essa "ausência de visão" o "ponto culminante de seu olhar". Cito Blanchot: "Son oeil, inutile pour voir, prenait des proportions extraordinaires, se développait d'une manière démesurée et, s'étendant sur l'horizon, laissait la nuit pénétrer en son centre pour en recevoir le jour. Par ce vide, c'était donc le regard et l'objet du regard qui se mêlaient." Essa imagem de um objeto que se insere entre o olho e a visão, confundindo o objeto do olhar e o olhar, o significante e o significado, retornará diversas vezes na obra de Blanchot. Algo tenta penetrar, deslizar para dentro dos personagens de Blanchot, e sempre através

\footnotetext{
48 Há uma noção de escritura presente aqui que é intimamente relacionada à obra de Derrida, especialmente no que tange sua crítica da fenomenologia, elaborada em Introduction à l'Origine de la Géometrie e outros escritos. A exploraremos a seguir. Quanto à morte, não obstante, podemos citar as palavras do livro de Timothy Clark: "(...) A partir do momento em que a noção de recuperação dialética em Hegel não é mais admissível, ambos Blanchot e Bataille antecipam Derrida ao escrever extensivamente sobre os 'nada', 'morte' e 'noite' enquanto forças que não podem ser inteiramente domadas ou domadas em um conceito ('morte' é já a condição de possibilidade de qualquer conceito). 'Escritura' então torna-se parte o nome para uma negatividade que não pode ser dominada ou reconvertida em uma positividade. $\mathrm{E}$ também torna-se um estranho modo do transcendental. Assim sendo, será necessário, finalmente, descartar o termo 'negatividade', já que ele não pode mais ser definido em oposição a sua antítese. Ao associar a escritura com uma irrecuperável perda - da consciência, presença e significado - Blanchot já antecipa, ao longo dos anos 50 , a noção de Derrida de escritura enquanto cinzas."- Derrida, Heidegger Blanchot - Sources of Derrida's Notion and Practice of Literature, p. 72-73.
} 
dos olhos; seus pensamentos, seus sentidos excedem em sentido, criando massas desordenadas e permitindo que essas massas adentrem seu ser mais íntimo, seus corpos, sua visão. A indiferenciação ou a materialização da visão - ao lado da voz, um dos polos da narrativa na visão blanchotiana - é um fenômeno recorrente nas ficções de Blanchot, como demonstra a presença quase infindável do tema da visão, do dia, do testemunho, etc., em suas obras ficcionais.

\begin{abstract}
Même s'il en avait contesté la vérité, il aurait eu le plus grand mal à ne pas croire à quelque chose d'extrême et de violent, car de toute évidence un corps étranger s'était logé dans sa pupille et s'efforçait d'aller plus loin. C'était insolite, parfaitement gênant, d'autant plus gênant qu'il ne s'agissait pas d'un petit objet, mais d'arbres entiers, de tout le bois frissonnant encore et plein de vie. II ne fit même plus attention aux détails des événements. Peut-être un homme se glissa-til par la même ouverture, il n'aurait pu l'affirmer ni le nier. II lui sembla que les vagues envahissaient l'espèce d'abîme qu'il était. (BLANCHOT, 2007, p. 18) ${ }^{49}$
\end{abstract}

Esse episódio, em que alguém ou algo atravessa os limites das córneas e retinas de Thomas, abertura através da qual mesmo as ondas do mar passarão, é central em meio aos outros episódios ficcionais da obra de Blanchot. Seus personagens são abismos, são aberturas através das quais os sentidos e as ficções passam, e não somente uma coisa ou outra - uma entidade localizada, específica, ou outra - mas todo o mar indiferenciado das coisas juntas, o entre, o neutro intervalo das coisas. "Aberturas por onde pode passar o sentido", nos dizia Jean-Luc Nancy, nisso muito blanchotiano, em um ensaio cujo objeto patente, ao menos, não era a obra de Blanchot, mas que muito bem poderia sê-lo. No episódio mencionado, em especial, é o pensamento materializado de Thomas que busca invadi-lo, violá-lo. "Em volta de seu corpo, ele sabia que seu pensamento, confundido com a noite, velava. Ele sabia, terrível certeza que ele também buscava um lugar para nele entrar. (...) Só, o corpo de Thomas subsistiu privado de sentido. E o pensamento, de novo dentro dele, trocou contatos com o vazio."

O terceiro capítulo nos apresenta Thomas retornando a seu hotel para jantar, preocupado com que os outros - nada nos é dito quanto ao ser desses

\footnotetext{
49 "Mesmo se ele houvesse contestado-Ihe a verdade, teria feito mal maior em não crer em algo de extremo e violento, pois de toda evidência um corpo estranho havia se alojado em sua pupila e se esforçava para ir mais longe. Isso era insólito, perfeitamente incômodo, tão mais incômodo que não tratava-se de um pequeno objeto, mas de árvores inteiras, de todo o bosque ainda tiritante e pleno de vida. Ele não dá mesmo atenção aos detalhes dos acontecimentos. Talvez um homem tenha deslizado pela mesma abertura, ele não poderia afirmá-lo nem negá-lo. Pareceu-lhe que as vagas invadiam a espécie de abismo que ele era."
} 
outros - percebessem sua "nova maneira de ser". Então Thomas encontra

Anne, a "cheia de graça", a dar crédito à etimologia do nome, imagem romanceada - em récit, igualmente - de Eurídice, na releitura do mito de Orfeu perpetrada por Blanchot em L'Espace Littéraire. A passagem deve ser citada em sua completude de modo a dar conta de sua importância no pensamento crítico e ficcional de Blanchot:

\begin{abstract}
A observer sa voisine,Thomas en fut frappé : c'était une grande fille blonde, dont la beauté se réveillait à mesure qu'il la regardait. Elle semblait avoir éprouvé un plaisir très vif lorsqu'il était venu s'asseoir auprès d'elle, mais maintenant elle se tenait avec une sorte de raideur, avec la volonté puérile de demeurer à l'écart, d'autant plus étrangère qu'il se rapprochait pour obtenir d'elle un signe d'encouragement. II continua cependant à la fixer, car toute sa personne, éclairée d'une lumière superbe, l'attirait.
\end{abstract}

Ayant entendu quelqu'un l'appeler : Anne (d'une voix très aiguë), voyant qu'elle, aussitôt, levait la tête, prête à répondre, il se décida à agir et, de toutes ses forces, frappa sur la table. Erreur de tactique, il n'en pouvait douter, geste peu heureux : le résultat ne s'en fit pas attendre. Chacun, comme indigné par une extravagance qu'on ne pouvait tolérer qu'en l'ignorant, s'enferma dans une réserve contre laquelle rien n'était plus possible. (BLANCHOT, 2007, p. 24) ${ }^{50}$

Desde já a arte - Anne - que emula, segundo mais de um intérprete ${ }^{51}$, a elusividade da obra de arte e a abertura ao espaço literário, obra de arte esta atingível somente através da negligência e jamais diretamente. Anne personifica, até certo ponto, a Eurídice do mito órfico. Deter-nos-emos mais longamente na releitura blanchotiana do mito órfico. Por hora basta notar que, exposto à pedagogia de Anne, Thomas encontra a possibilidade de uma abertura ao vazio, à vertigem do

\footnotetext{
50 "Ao observar sua vizinha, Thomas ficou impressionado: era uma grande senhorita loira, cuja beleza se revelava à medida que ele a perscrutava. Ela parecia ter provado um prazer muito grande quando ele veio sentar-se perto dela, mas agora ela se detia com um tipo de rigidez, com a vontade pueril de permanecer à parte, tão mais estranha que ele se aproximava para obter dela um signo de encorajamento. Ele continuou todavia a fixar-lhe o olhar, pois toda sua pessoa, clareada por uma luz soberba, o atraía. (...) Tendo escutado alguém chamar-lhe: Anne (com uma voz muito aguda), vendo que ela, imediatamente, erguia a cabeça, pronta para responder, ele se decidiu por agir e, com todas suas forças, bateu na mesa. Erro de tática, não havia dúvidas, gesto pouco feliz: o resultado não se fez atingir. Cada um, como que indignado por uma extravagância que não se podia tolerar senão a ignorando, se enclausurou em uma reserva contra a qual nada mais era possível."

51 Pensamos, por exemplo, no ensaio de Garin V. Dowd, "Glisser dans le vide", Blanchot, Thomas l'obscur and the space of literature, um dos poucos dedicados a interpretar a primeira obra - de 1941 - e a releitura dessa primeira obra - de 1950 -, ao lado de Jacques Derrida, que lidou com ela em alguns de seus seminários da década de 1970, e de alguns outros poucos leitores, como Thomas Schestag, em seu ensaio "Mantis, Relics" (presente em Yale French Studies, 93, "The Place of Maurice Blanchot", 1998), e Jean Starobinski, em ensaio publicado na edição especial da Revue Critique dedicada à obra de Blanchot, de 1966: "Thomas l'obscur, chapitre premier", além de parte do texto "The Negative Eschatology of Maurice Blanchot", de Kevin S. Fitzgerald.
} 
espaçamento, ao deslizamento infinito do sentido. Thomas sempre oscila: por vezes busca fixar-se, busca o sedentarismo no e do pensamento do mundo. Mas sempre é levado a deslizar para outras experiências, outros acontecimentos, outros sentidos. Em seu primeiro encontro, logo em seu primeiro encontro Anne, é importante notar, convocado ao fora. Depois de algumas tentativas mal sucedidas de chamar a atenção, Thomas insiste, encarando a todos presentes no recinto, que reagem mal, mas nenhum reage tão mal quanto a própria Anne, que se levanta, arruma os cabelos, e parte em silêncio. Anne parece esvair-se, ela cuja presença havia a princípio reconfortado o aturdido Thomas. "Ali não havia mais que um ser cuja fragilidade aparecia na beleza murcha e que perdia mesmo toda realidade, como se os contornos do corpo não houvessem sido desenhados pela luz, mas por uma fosforescência difusa, emanada, cria-se, dos ossos." (BLANCHOT, 1950, p. 24). O que Thomas vê o torna ainda mais solitário. É o momento em que Anne o convoca ao fora, apelo que ele atende sem saber - como é a situação com os personagens de Blanchot, desde os primeiros romances até a sequência de récits escritos em sua maioria nos anos da década de 1950 - o motivo pelo qual sucumbe ao chamado de Anne.

\begin{abstract}
Au même moment, la jeune fille l'appela du dehors d'une voix décidée, presque trop forte, qui résonnait d'une manière impérieuse, sans qu'on pût distinguer si cette force venait de l'ordre qui était transmis ou seulement de la voix qui le prenait trop au sérieux. Le premier mouvement de Thomas, très sensible à cette invitation, fut d'obéir en se précipitant dans l'espace vide. Puis, lorsque le silence eut recouvert l'appel, il ne fut plus aussi sûr d'avoir réellement entendu son nom et il se contenta de prêter l'oreille en espérant qu'on l'appellerait à nouveau. Tout en écoutant, il songea à l'éloignement de tous ces gens, à leur mutisme absolu, à leur indifférence. C'était pur enfantillage que d'espérer voir toutes les distances supprimées par un simple appel. C'était même humiliant et dangereux. Là-dessus, il releva la tête et, ayant constaté que tout le monde était parti, à son tour il quitta la pièce. (BLANCHOT, 2007, p. 26.) ${ }^{52}$
\end{abstract}

Embora Thomas não compreenda o porque de ceder ao chamado ao lado de fora feito quase que inadvertidamente por Anne, e embora o silêncio acachapante o

\footnotetext{
52 "No mesmo momento, a senhorita o chamou do fora com uma voz decidida, quase demasiado forte, que ressoava de uma maneira imperiosa, sem que se pudesse distinguir se esta força vinha da ordem que era transmitida ou somente da voz que a levava demasiado a sério. O primeiro movimento de Thomas, muito sensível a esse convite, foi de obedecer, precipitando-se no espaço vazio. Então, quando o silêncio havia recoberto o apelo, ele não estava mais tão certo de ter realmente escutado seu nome e se contentou em escutar, esperando que o chamassem novamente. Escutando, sonhou com o afastamento de todas essas pessoas, com seu mutismo absoluto, com sua indiferença. Era pura infantilidade esperar ver todas as distâncias suprimidas por um simples apelo. Era até mesmo humilhante e perigoso. Logo em seguida ele ergueu a cabeça e, tendo constatado que todo mundo havia partido, por sua vez saiu do aposento."
} 
impeça mesmo de ter certeza de que fora seu nome o evocado, embora considere mesmo - Thomas ou o autor - que há algo de infantil em "esperar ver todas as distâncias suprimidas por um simples apelo", Thomas se dirige ao lado de fora. É o começo do que se pode chamar de jornada órfica ao lado de sua companheira. Blanchot deixa em suspenso, contudo, o desenrolar da relação de Thomas com Anne.

No capítulo seguinte, o leitor encontra Thomas lendo em seu quarto ${ }^{53}$. Esse capítulo se insere algo à parte do resto da obra, no sentido de uma mudança de cena, pois não há sequência episódica ou temporal, ou as há muito escassas, nas narrativas de Blanchot. O narrador nos diz que Thomas lê, e lê obstinadamente, lê o mesmo livro, aberto nas mesmas páginas. Lê com "minúcia e atenção insuperáveis". Thomas se detém diante de cada signo "como o macho quando o louva-deus fêmea vai lhe devorar". A menção ao canibalismo de um artrópode não é fortuita: Thomas não pode simplesmente ler o texto, como veremos. As palavras o atraem, decerto. No próprio ler, Thomas "então deslizou em direção a esses corredores de que ele se aproximou sem defesa até o instante em que fora percebido pelo íntimo da palavra." (BLANCHOT, 1950, p. 27). Thomas não se assusta com o insólito de sua experiência de leitura, com os olhos que as palavras se tornam, e que agora o fitam. Pelo contrário, considera agradável a "centelha de vida" que pensa haver acordado. Thomas se vê, a princípio, na palavra-olho que o vê: reflete, encontra-se.

Son plaisir même devint très grand. II devint si grand, si impitoyable qu'il le subit avec une sorte d'effroi et que, s'étant dressé, moment insupportable, sans recevoir de son interlocuteur un signe complice, il aperçut toute l'étrangeté qu'il y avait à être observé par un mot comme par un être vivant, et non seulement par un mot, mais par tous les mots qui se trouvaient dans ce mot, par tous ceux qui l'accompagnaient et qui à leur tour contenaient en eux-mêmes d'autres mots, comme une suite d'anges s'ouvrant à l'infini jusqu'à l'oeil de l'absolu. (BLANCHOT, 2007, p. 28) ${ }^{54}$

\footnotetext{
${ }^{53}$ Esse capítulo, entre os mais comentados pela crítica, foi o que levou Jacques Lacan, em seu seminário sobre a Identificação, de 1961-1962, a dizer que Blanchot havia "(...) ido mais longe que qualquer um, presente ou passado, na via da realização do fantasma." Lacan também se refere algo efusivamente a Blanchot como "o bardo de nossas Letras".

54 "Seu prazer mesmo tornou-se muito grande. Tornou-se tão grande, tão implacável, que ele o sofreu com uma sorte de temor e que, opondo-se, momento insuportável, sem receber de seu interlocutor um sinal cúmplice, percebeu toda a estranheza que havia em ser observado por uma palavra como por um ser vivo, e não somente uma palavra, mas todas as palavras que se encontravam nessa palavra, por todas essas que a acompanhavam e que por sua vez continham elas mesmas outras palavras, como uma série de anjos se abrindo ao infinito até o olho do absoluto."
} 
Thomas, o Thomas pronto para a leitura, que sentia mesmo prazer em perscrutar o íntimo da palavra e ser visto de volta, esse Thomas reflexivo se vê agora invadido pela palavra, e percebe toda a estranheza desse contato íntimo com a vivacidade das palavras que se encontram nessa palavra, "como uma sequência de anjos se abrindo ao infinito até o olho do absoluto". Passagem epigonal do "romance" em questão, devemos lembrar, para evitar mal-entendidos, da etimologia da palavra "absoluto", que em Blanchot, como foi sugerido por mais de um crítico, remete ao latim absolvere, cortar, cindir, romper os elos. Esse encontro com a palavra que leva inexoravelmente a outras palavras, que contém mesmo outras palavras, até o infinito da ausência de relação, mostrar-se-á fundamental na ficção de Blanchot, sendo esse um dos primeiros momentos em que aparece com clareza em sua ficção. As palavras, então, começam a ler Thomas. Ele é então invadido e invasor a um só tempo: “(...) ele entrou com seu corpo vivo nas formas anônimas das palavras, Ihes dando sua substância, formando suas relações, oferecendo à palavra ser seu ser." Thomas fica fascinado no momento em que crê ler. Explorado pelas palavras, Thomas se reconhece, com desgosto, no livro que lê. Seria Thomas l'obscur esse livro? Blanchot não confirma, mas parece ser o caso (nesse sentido, há e não há aqui a presença da mise-en-abyme, como será o caso de outro texto, $L a$ folie du jour, posterior, que comentaremos no capítulo V). Esse é, de todo modo, o segundo encontro de Thomas com a noite. Ele, então, encontra-se na solidão absoluta, isto é, livre de qualquer elo. Thomas sente uma presença estranha, não consegue discerni-la. Nesse momento tenta perfurar a noite, dar-se a luz com um gesto da mão. Thomas sabia que essa presença não existia, e no entanto ela o envolvia por completo. Então um outro ser substitui esse primeiro, ainda mais obscuro. Alguém se aproxima de Thomas, "invisível e certo". Thomas tenta fugir, tenta se defender. "Ele se sentia sempre mais próximo de uma ausência sempre mais monstruosa de que o encontro demandava o infinito do tempo" (BLANCHOT, 1950, p. 30). Thomas combate, tenta se apropriar da palavra tornada monstro, tenta levá-la à intimidade mais profunda, fazer da palavra seu domínio. Então vem o fim da noite, a luz se estende. Thomas se torna opaco: uma fadiga infinita invade seu corpo. Assim termina o capítulo: após tentar se apropriar do texto, após digladiar-se com o ser monstruoso da palavra, a fadiga e o sono tomam conta de Thomas. Uma vez mais, ele fracassa em seu intuito de estabelecer uma correspondência entre as letras e a experiência. 
A chaque fois, Thomas était repoussé jusqu'au fond de son être par les mots mêmes qui l'avaient hanté et qu'il poursuivait comme son cauchemar et comme l'explication de son cauchemar. II se retrouvait toujours plus vide et plus lourd, il ne remuait plus qu'avec une fatigue infinie. Son corps, après tant de luttes, devint entièrement opaque et, à ceux qui le regardaient, il donnait l'impression reposante du sommeil, bien qu'il n'eût cessé d'être éveillé. (BLANCHOT, 2007, p. 33) ${ }^{55}$

Este episódio - capítulo - é interessante por demonstrar de maneira evidente e inicial, como mencionamos, uma das estruturas recorrentes na obra de Blanchot, a que diferentes leitores deram diferentes nomes, mas que caracteriza-se, basicamente, por uma radicalização da estrutura dita "autorrepresentativa" da mise en abyme. Esse artifício se repete ao longo de diversos textos, e em especial os que elegemos enquanto objeto. Basta notar, por enquanto, que embora Thomas leia um livro - em aparência, um livro obscuro e monstruoso como Thomas l'obscur -, a mise en abyme, que em outros registros literários costuma ter a função de evidenciar a literariedade da ficção, ou denunciar o caráter de fiç̧ão da ficção, peculiarmente, não chega a se realizar: ao leitor não é permitido dizer com clareza se trata-se do livro Thomas l'obscur, e mesmo Thomas não é capaz, pois sendo derrotado em seu esforço reiterado em ler as palavras dispostas no livro. Não vence nem mesmo a extensão de duas páginas. A bem dizer, não se delineam os dois extratos mínimos necessários para que se disponha de uma mise en abyme de tipo explicativo ${ }^{56}$, em que o dissociamento de um nível a outro produz o efeito "abismal", mas uma mise en abyme lacunar, intervalar, que evoca uma incompletude estrutural mais profunda, experimento característico da obra ficcional e ensaística de Blanchot.

Sigamos com o texto. No capítulo seguinte, Thomas desce "em direção ao meio da segunda noite". Um gato passa por Thomas. Então ocorre um estranho monólogo, em que a voz do gato e a voz de Thomas parecem se confundir. $\mathrm{O}$ gato diz, em certo momento, se confundir agora com a noite, ser mais obscuro que a própria noite. E que "isso a que se chama de além está findo para mim." Thomas então vive uma experiência que se repete um pouco por toda a parte nos escritos ficcionais de Blanchot: a da impossibilidade da morte, em que a morte falha ou não chega a acontecer, descrita no trecho a seguir:

\footnotetext{
55 "A cada vez, Thomas era repelido até o fundo de seu ser pelas palavras mesmas que o haviam assombrado e que ele perseguia como seu pesadelo e como a explicação de seu pesadelo. Ele se encontrava sempre mais vazio e mais pesado, não se mexia mais senão com uma fadiga infinita. Seu corpo, depois de tantas lutas, tornara-se inteiramente opaco e, àqueles que o olhavam, ele dava a impressão de repouso do sono, ainda que não houvesse cessado de estar desperto."

${ }^{56}$ DÄLLENBACH, Lucien. Le récit spéculaire. Essai sur la mise en abyme.
} 
De même que l'homme qui se pend, après avoir repoussé l'escabeau sur lequel il s'appuyait encore, dernier rivage, au lieu de ressentir le saut qu'il fait dans le vide, ne sent que la corde qui le tient, tenu jusqu'au bout, plus que jamais attaché, lié comme il ne l'a jamais été à l'existence dont il voudrait se détacher, lui aussi se sentait, au moment où il se savait mort, absent, tout à fait absent de sa mort. $\mathrm{Ni}$ son corps qui lui laissait au fond de lui-même le froid que donne le contact d'un cadavre et qui n'est pas le froid mais l'absence de contact, ni l'obscurité qui suintait de tous ses pores et, même lorsqu'il était visible, faisait qu'on ne pouvait se servir d'aucun sens, d'aucune intuition et pas davantage d'une pensée pour le voir, ni ce fait qu'à aucun titre il ne pouvait passer pour vivant ne suffisait à le faire passer pour mort. Et ce n'était pas un malentendu. II était réellement mort et en même temps repoussé de la réalité de la mort. II était, dans la mort même, privé de la mort, homme affreusement anéanti, arrêté dans le néant par sa propre image, par ce Thomas courant au-devant de lui, porteur de flambeaux éteints et qui était comme l'existence de la dernière mort." (BLANCHOT, 2007, p. 40) ${ }^{57}$

Thomas encontra, portanto, nesse outro - simulacro de si mesmo - que se apresenta junto a si em sua tumba, não somente a morte, mas a impossibilidade da morte. Falaremos mais adiante sobre as relações entre essa "impossibilidade da morte", em Blanchot, bastando agora lembrar algumas palavras sobre a morte presentes no livro O espaço literário: “(...) ela é o abismo do presente, o tempo sem presente com o qual eu não tenho relação, isso em direção a que eu não posso me lançar, porque nela eu não morro, eu decaí do poder de morrer, nela se morre, não se cessa e não se finda de morrer." (BLANCHOT, 1951, p. 202). Muito tempo antes de formular, em sua crítica - em especial nos textos a respeito das obras de Franz Kafka e de Rainer Maria Rilke - literária produzida ao longo da década de 1950, Blanchot já havia experimentado, em sua ficção, sua conceitualidade acerca da morte. Thomas tenta se apropriar da morte, tenta viver sua morte, tê-la presente, e não tem sucesso. A noite o envolve: “(...) ele via, ele entendia a intimidade de um infinito em que estava encerrado pela ausência mesma de limites. Ele sentia como uma existência opressiva a inexistência deste vale da morte." (BLANCHOT, 1950, p. 41). Curiosamente, o final do capítulo $V$, onde a experiência de Thomas com Anne ainda é da ordem do anúncio, Thomas reencontra algo da possibilidade na morte,

\footnotetext{
57 "Assim como o homem que se enforca, após haver repelido a escada sobre a qual ainda se apoiava, última margem, no lugar de ressentir o salto que faz no vazio, não sente senão a corda que o detém, tenso até o fim, mais que nunca preso, ligado como jamais fora à existência da qual gostaria de desprender-se, ele também se sentia, no momento em que se sabia morto, ausente, inteiramente ausente de sua morte. Nem seu corpo que lhe deixava no fundo dele mesmo o frio que dá o contato de um cadáver e que não é o frio mas a ausência de contato, nem a obscuridade que esvaia de todos seus poros e, mesmo quando ele era visível, fazia com que não se pudesse servir de sentido algum, de intuição alguma e não mais de um pensamento para vê-lo, nem esse fato que de modo algum poderia passar por vivo bastaria para fazê-lo passar por morto. E isso não era um mal entendido. Ele estava realmente morto e ao mesmo tempo repelido da realidade da morte. Ele estava, na morte mesma, privado da morte, homem abominavelmente anulado, detido no nada por sua própria imagem, por esse Thomas correndo à sua frente, portador de tochas apagadas e que era como a existência da última morte."
} 
"reencontrando o sopro na asfixia" (BLANCHOT, 1950, p. 40). A passagem a seguir, que finaliza o capítulo em questão, nos mostra um Thomas triunfante, ctônico, a sair vitorioso de sua cripta:

\begin{abstract}
“II marchait, seul Lazare véritable don't la mort même était ressuscitée. II avançait, passant par-dessus les dernières ombres de la nuit, sans rien perdre de sa gloire, couvert d'herbes et de terre, allant, sous la chute des étoiles, d'un pas égal, du même pas qui, pour les hommes qui ne sont pas enveloppés d'un suaire, marque l'ascension vers le point le plus précieux de la vie." - (BLANCHOT, 2007, p. 42) ${ }^{58}$
\end{abstract}

Como mais de um intérprete notou, Thomas guarda ainda algo do Ulisses redivivo, em retorno à Ítaca, algo da interioridade do cogito; sua relação com a morte é diametralmente oposta à de Anne, como veremos a seguir. Grande parte do livro é dedicada a tratar dessa relação. Anne é anunciada no capítulo III, e do VI em diante domina a narrativa. Interessante notar como Anne sempre tenta fugir de Thomas, como no início do capítulo VI: "Anne o viu aproximar-se sem surpresa, este ser inevitável em quem ela reconhecia aquele de que teria tentado fugir em vão, que ela reencontrava todos os dias." (BLANCHOT, 1950, p. 43) Anne leva Thomas por caminhos inauditos, ela, dona de uma estranha "pedagogia da morte", como foi chamada por outros intérpretes. "(...) Com a ingenuidade de Josué detendo o sol para ganhar tempo", Anne crê que as coisas "continuam", crê no fluxo ininterrupto das coisas, em sua continuidade. Mas não há mudança, tudo que há é a repetição da mesma cena mortal. É o momento em que Thomas é levado por Anne, "arrastado", em uma repetição precisa do mito órfico. A passagem merece ser citada em sua totalidade:

(...) Pourtant, ce jour-là, comme si un cadavre qu'on porte dans un lit, puis dans un autre, changeait vraiment de place, elle se leva, marcha devant Thomas et l'entraîna vers le petit bois voisin sur une route où ceux qui venaient au-devant de luile voyaient s'éloigner ou le croyaient immobile. En vérité, il marchait réellement et, avec un corps pareil aux autres, quoiqu'il fût aux trois quarts consumé, il pénétrait dans une région où, si lui-même disparaissait, il voyait aussitôt les autres tomber dans un autre néant qui les éloignait plus de lui que s'ils eussent continué à vivre. Sur cette route, chaque homme qu'il croisait mourait. Chaque homme, si Thomas détournait les yeux, mourait avec lui d'une mort qu'aucun cri n'annonçait. E les regardait, et déjà il les voyait perdre sous son regard toute ressemblance, ayant au front une petite blessure par laquelle s'échappait leur visage. Ils ne disparaissaient pas, mais ils n'apparaissaient plus. Du plus loin qu'ils surgissaient,

\footnotetext{
58 "Ele marchava, único Lázaro verídico cuja morte mesma era ressuscitada. Ele avançava, passando por cima dessas últimas sombras da noite, sem nada perder de sua glória, coberto de ervas e de terra, indo, sob a queda das estrelas, de um passo constante, do mesmo passo que, para os homens que não são envolvidos por um sudário, marca a ascensão em direção ao ponto mais precioso da vida."
} 
ils étaient informes et muets. Plus près, s'il les touchait, s'il dirigeait sur eux non pas son regard, mais le regard de cet oeil éclatant et invisible qu'il était à tout instant tout entier, plus près encore, presque confondu avec eux, les prenant soit pour son ombre, soit pour des âmes mortes, les respirant, les léchant, s'enduisant de leur corps, il n'en recevait pas la moindre sensation, ni la moindre image, aussi vide d'eux qu'euxmêmes étaient vides de lui. Enfin, ils passaient. Ils s'en allaient définitivement. Ils glissaient sur une pente vertigineuse vers une contrée d'où plus rien d'eux n'était visible, si ce n'est parfois, comme les grandes traînées de lumière, leur dernier regard phosphorescent au ras de l'horizon. C'était une rafle mystérieuse et terrible. Derrière lui plus de paroles, plus de silence, plus d'arrière et plus d'avant. L'espace qui l'entourait était le contraire de l'espace, pensée infinie où ceux qui entraient, la tête couverte d'un voile, n'existaient que pour rien. Dans cet abîme, Anne, seule, résistait. Morte, dissipée dans le milieu le plus proche du vide, elle y trouvait encore des débris d'êtres avec lesquels elle entretenait, durant le naufrage, une sorte de ressemblance familiale sur ses traits. S'il l'abordait de face, brutalement, pour la surprendre, elle lui présentait toujours un visage. Elle changeait sans cesser d'être Anne. Elle était Anne, n'ayant plus aucune similitude avec Anne. Avec sa figure et tous ses traits, et pourtant tout à fait pareille à une autre, elle restait la même, Anne, Anne complète qu'on ne pouvait nier. (BLANCHOT, 2007, p. 46) ${ }^{59}$

Nesse abismo, que lembra, de certo modo, o Hades grego, pois cada homem que Thomas cruza morre no momento em que esse desvia os olhar, nesse espaço confuso, ou o oposto do espaço, como coloca Blanchot, Anne é a única a resistir, morta, "dissipada no meio mais próximo do vazio, aí encontrando ainda destroços de seres com os quais entretinha, durante o naufrágio, um tipo de semelhança familiar com seus traços". Anne se tornou a inquietude do cadáver, descrita por Blanchot n'O

\footnotetext{
59 "No entanto, naquele dia, como um cadáver que se posta em um leito, então em outro, troca verdadeiramente de lugar, ela se levantou, caminhou diante de Thomas e o arrastou ao pequeno bosque vizinho sobre um caminho em que aqueles que vinham diante dele viam-no distanciar-se ou criam-no imóvel. Na verdade, ele marchava realmente e, com um corpo semelhante aos outros, ainda que estivesse consumido já de três quartos, penetrava em uma região em que, se ele mesmo desaparecia, via imediatamente os outros caírem sobre um outro nada que os distanciava mais dele que se houvessem continuado a viver. Sobre esse caminho, cada homem que ele cruzava morria. Cada homem, se Thomas desviasse os olhos, morria com ele de uma morte que nenhum grito anunciava. Ele os olhava, e já os via perder sob seu olhar toda semelhança, tendo na frente uma pequena ferida pela qual escapava seu rosto. Eles não desapareciam, mas tampouco apareciam. Quão mais longe surgissem, eram informes e mudos. Mais perto, se ele os tocava, se ele dirigia a eles não seu olhar, mas o olhar deste olho radiante e invisível que ele era a todo instante de todo indiviso, mais perto ainda, quase confundido com eles, tomando-os seja por sua sombra, seja por almas mortas, respirando-os, lambendo-os, ungindo-se de seus corpos, ele não recebia a menor sensação, nem a menor imagem, tão vazio deles quanto eles estavam vazios dele. Enfim, eles passavam. Eles iam-se definitivamente. Eles deslizavam sobre uma inclinação vertiginosa em direção a uma superfície de onde mais nenhum deles era visível, senão por vezes, como grandes nódoas de luz, seu último olhar fosforescente na linha do horizonte. Era um saque misterioso e terrível. Atrás deles mais palavras, mais silêncio, mais atrás e mais antes. $O$ espaço que 0 circundava era 0 contrário do espaço, pensamento infinito onde esses que entravam, a cabeça coberta de um véu, não existiam senão pelo nada. Neste abismo, Anne, só, resistia. Morta, dissipada no meio mais próximo do vazio, ela aí encontrava ainda destroços de seres com os quais mantia, durante o naufrágio, uma sorte de semelhança familiar com os traços. Se ele a abordasse diretamente, brutalmente, para surpreendê-la, ela lhe apresentava sempre um rosto. Ela mudava sem cessar de ser Anne. Era Anne, não tendo mais nenhuma semelhança com Anne. Com sua figura e todos seus traços, e no entanto semelhante a uma outra, ela permanecia a mesma, Anne, Anne completa que não se podia negar."
} 
Espaço Literário ${ }^{60}$ : é a mesma e é outra, incapaz de se situar entre o mesmo e o distinto, tal qual o cadáver. O jogo entre Thomas e Anne lembra em tudo o de Orfeu e Eurídice: ela se detém diante dele, se aproxima, fazendo-o delirar com a liberdade, um turbilhão de pensamentos. Thomas não tem, não pode ter certeza, e questiona se é Anne de fato em diversos momentos: "É você?", diz ainda no final do capítulo em questão. Então, ao fim do capítulo, o narrador sai-se com a seguinte passagem, que parece evocar, de modo oblíquo, o próprio livro que o leitor tem em mãos, ao tratar dos obscuros sentimentos de Anne em relação a Thomas: “(...) Era uma história vazia de acontecimentos, vazia ao ponto de que toda lembrança e toda perspectiva aí foram suprimidas, e no entanto tirando desta ausência seu curso inflexível que parecia tudo levar, com um irresistível movimento, em direção a uma catástrofe iminente. Que aconteceria? Ela não sabia de nada, mas, pondo toda sua vida em esperar, sua impaciência se confundia com a esperança de participar em um cataclisma geral em que, ao mesmo tempo que os seres, seriam destruídas as distâncias que separam os seres." Anne, a essa altura, ainda partilha do sonho da imediatez, chamado de "phantom of immediacy" por Geoffrey Hartman ${ }^{61}$, situação que muda ao longo do récit, e é uma de suas transformações cruciais, como veremos.

No princípio do capítulo seguinte encontra-se um discurso direto de Anne, que esclarece algo de sua relação órfica com Thomas.

- Oui, dit-elle, je voudrais vous voir lorsque vous êtes seul. Si jamais je pouvais me trouver devant vous en m'écartant tout à fait de vous, j'aurais une chance de vous rejoindre. Ou plutôt je sais que je ne vous rejoindrais pas. La seule possibilité que j'aurais de diminuer la distance qui nous sépare serait de m'éloigner infiniment. Or, je suis déjà infiniment loin et ne puis m'éloigner davantage. Dès que je vous touche, Thomas... (BLANCHOT, 2007, p.57) 62

O único jeito de diminuir a distância que nos separa: distanciar-nos infinitamente. “(...) mas já estou infinitamente distante e não posso me distanciar mais. Desde que vos toco, Thomas...". Anne expressa o double bind - se o nome cabe nesse caso, e pensamos que sim - descrito por Michel Foucault em La pensée

\footnotetext{
${ }^{60}$ Especialmente no ensaio "Les deux versions de l'imaginaire".

${ }^{61}$ HARTMAN, Geoffrey. The fulness and nothingness of literature.

62 "- Sim, disse ela, eu gostaria de ver-te quando estiveres só. Se nunca eu pudesse encontrar-me diante de ti em me afastando de ti inteiramente, eu teria uma chance de chegar a você. Ou antes eu sei que não chegaria a você. A única possibilidade que eu teria de diminuir a distância que nos separa seria distanciar-me infinitamente. Ora, eu estou já infinitamente longe e não posso me distanciar ainda mais. Desde que eu vos toco, Thomas..."
} 
du dehors: em Blanchot há um par essencial, atração e negligência. É o caso específico da leitura blanchotiana do mito órfico: Orfeu, imagem do poeta, só pode dar testemunho do imediato quando se desvia. E tudo, por fim, recomeça. Anne fala com Thomas: "ela não podia falar, e no entanto falava"; "tinha o ar de expressar sem palavra o sentido das palavras". Mas há momentos em que as palavras passam a falar em Anne: "(...) bruscamente, ela se deixou arrebatar por um fluxo de palavras que ela pronunciava com a voz quase baixa, com inflexões variadas, como se não procurasse senão se divertir com os barulhos e clarões de sílabas. Poder-se-ia dizer que ao falar uma linguagem de que o caráter infantil não permitia que se a tivesse por linguagem, ela dava às palavras insignificantes o aspecto de palavras incompreensíveis". A puerilidade da fala de Anne é como um desafio para Thomas. Seu vocabulário se anula. Anne envelhece; visita dias "de todo estranhos aos dias humanos", então se eleva a "tempos soberanos", na "intimidade das coisas puras", e conhece assim o sofrimento. Anne não sabe porque, mas erra por corredores vazios, onde busca os reflexos abscônditos de uma luz que se desloca sem cessar, “alma já perdida”, marchando já sem motivo algum. Anne antagoniza Thomas, ou ao menos é essa a impressão que atinge o leitor. Anne, então, esse "tempo" que Anne se torna penetra, por fim, a pessoa de Thomas (os personagens de Blanchot, como mencionamos, tem essa curiosa tendência a serem invadidos por materializações da voz e do olhar). O texto de Blanchot - de que já foi dito impossível o resumo, e isso de acordo com as intenções do filósofo-autor - talvez torne mais clara a metamorfose a que Thomas é submetido, quando Anne lhe invade a existência:

II raisonnait donc avec au plus intime de son argument l'absolu contradicteur, il pensait avec au fond de sa pensée l'ennemi et le sujet de toute pensée, son parfait antagoniste, ce temps, Anne, et la recevant mystérieusement en lui, il se vit aux prises pour la première fois avec un entretien sérieux. C'est dans ces conditions qu'elle pénétra, forme indécise, dans l'existence de Thomas.

Tout y semblait désolé et morne. Rivages déserts où se désagrégeaient lentement, abandonnées après un naufrage grandiose par la mer à jamais retirée, des absences de plus en plus profondes. Elle passa par d'étranges cités mortes où, au lieu de formes pétrifiées, de circonstances momifiées, elle rencontra une nécropole de mouvements, de silences, de vides; elle se heurta à l'extraordinaire sonorité du néant qui étendirent des chutes admirables, le sommeil sans rêve, l'évanouissement qui ensevelit les morts dans une vie de songe, la mort par laquelle tout homme, même l'esprit le plus faible, devient l'esprit même. Dans cette exploration qu'elle avait entreprise si naïvement, en croyant trouver la phrase décisive sur ellemême, elle se reconnut passionnément en quête de l'absence d'Anne, du néant le plus absolu d'Anne. Elle crut comprendre - ô cruelle illusion - que l'indifférence qui coulait le long de Thomas comme une eau solitaire, venait de l'infiltration, dans des régions où elle n'aurait jamais dû pénétrer, de l'absence 
fatale qui avait réussi à rompre tous les barrages, de sorte que, voulant à présent découvrir cette absence nue, ce négatif pur, l'équivalent de la pure lumière et du profond désir, elle dut se plier, pour l'atteindre, à de grandes épreuves. II lui fallut, pendant des vies, polir sa pensée, la débarrasser de tout ce qui en fait un misérable bric-à-brac, le miroir qui se mire, le prisme avec soleil intérieur : il lui fallait un moi sans sa solitude de verre, sans cet oeil atteint depuis si longtemps de strabisme, l'oeil dont la suprême beauté est de loucher le plus possible, l'oeil de l'oeil, la pensée de la pensée. (BLANCHOT, 2007, p. 67) ${ }^{63}$

\section{Quando participa da existência de Thomas - "participa" num sentido talvez} literal, já que Blanchot descreve o ato como uma jornada por "estranhas cidades mortas", "necrópole de movimentos, de silêncios, de vazios", Anne encontra uma ausência absoluta, aquática, como a de Thomas, também ela um naufrágio absoluto, como descreve o narrador. Vê-se, então, na busca da ausência de Anne, do "nada o mais absoluto de Anne". Mais e mais ausente, mais e mais rarefeita, Anne podia agora ser confundida com o abismo mesmo, avançando para além de si mesma, em contato com a "nudez absoluta", e passa por estágios da ausência: "ausência de barulho o silêncio", "ausência de ser a morte", mas esses nadas não bastam a Anne: nem mesmo o nada abissal de Pascal ${ }^{64}$, "esse nada tão morno e fácil em que permanecia Pascal"; Anne, então, vê-se em contato com "ausências de diamante", "ausência de silêncio", "ausência de morte”, lugares onde não pode mais tomar pé, não pode mais se situar, e então cai em círculos, cada vez maiores, "análogos aos

\footnotetext{
63 "Ele raciocinava então com o mais íntimo de seu argumento o absoluto contraditor, ele pensava com o fundo de seu pensamento o inimigo e o sujeito de todo pensamento, seu perfeito antagonista, esse tempo, Anne, e recebendo-a misteriosamente em si, ele se via às voltas pela primeira vez com uma conversa séria. É nessas condições que ela penetrou, forma indecisa, na existência de Thomas. (...) Tudo aí parecia desolado e morno. Orlas desertas onde se desagregavam lentamente, abandonadas após um naufrágio grandioso pelo mar para sempre retirado, ausências mais e mais profundas. Ela passou por estranhas cidades mortas onde, no lugar de formas petrificadas, de circunstâncias mumificadas, encontrou uma necrópole de movimentos, de silêncios, de vazios; ela colidiu-se com a extraordinária sonoridade do nada que é feita do inverso do som e, diante dela, se estenderam quedas admiráveis, o sono sem sonho, o desvanecimento que sepulta os mortos em uma vida de sonho, a morte pela qual todo homem, mesmo o espírito mais frágil, torna-se o espírito mesmo. Nesta exploração que ela havia empreendido tão ingenuamente, crendo encontrar a frase decisiva sobre ela mesma, se reconheceu apaixonadamente em busca da ausência de Anne, do nada mais absoluto de Anne. Ela creu compreender - oh, cruel ilusão - que a indiferença que fluia ao longo de Thomas como uma água solitária vinha da infiltração, em regiões onde ela não deveria jamais penetrar, da ausência fatal que havia conseguido romper todas as barreiras, de sorte que, querendo agora descobrir esta ausência nua, esse negativo puro, o equivalente da luz pura e do desejo profundo, ela teve que dobrar-se, para atingir, com grandes dificuldades. Foi-lhe necessário, durante vidas inteiras, polir seu pensamento, desembaraçar-se de tudo isso que fazia dela uma ruína miserável, o espelho que se mira, o prisma com sol interior: era-lhe necessário um eu sem sua solitude de vidro, sem este olho golpeado há tanto tempo de estrabismo, o olho cuja suprema beleza é olhar de soslaio o mais possível, o olho do olho, o pensamento do pensamento."

64 "(...) Afinal que é o homem dentro da natureza? Nada, em relação ao infinito; tudo, em relação ao nada; um ponto intermediário entre o tudo e o nada. Infitamente incapaz de compreender os extremos, tanto o fim das coisas quanto o seu princípio permanecem ocultos num segredo impenetrável, e é-lhe igualmente impossível ver o nada de onde saiu e o infinito que o envolve." (PASCAL, Pensées)
} 
do inferno". Nesse momento, Anne, como numa epifania, escuta seu nome sendo chamado. No "coração do nada", ela se introduz em presença, e aí se joga - no interior de Thomas? - como "cadáver, nada inassimilável, Anne que existia ainda e que não existia mais, suprema zombaria ao pensamento de Thomas. Thomas, portanto, representa ainda uma tentativa de superar a ausência, o vazio representados por Anne. Anne, embora oscile, ao longo da narrativa, entre um ser de substância e de ausência, angelical e diabólico, nesse momento significa a ausência instalada no interior poroso da figura de Thomas.

O IX capítulo nos mostra uma Anne muda, estendida sobre o solo, silenciosa e unida ao silêncio, que havia assimilado durante a "noite" de seu encontro com Thomas "algo de imaginário", "espinha de fogo" que a levava a rejeitar sua própria existência. Embora nada houvesse mudado em seu aspecto, identificá-la em sua pessoa era agora impossível ao olhar, dada a "semelhança perfeita de seus traços", no "verniz de naturalidade e de sinceridade deposto pela noite", em nada modificada e modificada por completo. Blanchot chama a visão de Anne, nesse momento, de "espetáculo proibido". De visão natural, a visão de Anne passa a "enigma", que cega os olhos, causando náusea em quem a lê, como se Anne, após sua jornada na existência de Thomas, houvesse se tornado um simulacro da Anne anterior, vívida, sorridente, como se essa nova pessoa que se descortina houvesse devorado a outra Anne, "mistério oculto na ausência de mistério". O dia penetra o quarto em que Anne se encontra, "com a intenção derrisória de dar fim à noite", proclamando a palavra de ordem: "a vida continua". Quando Thomas adentra o recinto, Anne percebe que a obscuridade desse ser já lhe invadiu por completo o ser:

Non seulement tout motif d'une communication claire était détruit, mais à Anne il semblait que le mystère de cet être eût passé dans son propre coeur, là même où il ne pouvait plus être saisi que comme une question éternellement mal posée. Et lui, au contraire, dans la silencieuse indifférence de sa venue, apparaissait d'une clarté offensante, sans le plus faible, le plus rassurant indice d'un secret. Elle avait beau le regarder avec les regards troubles de sa passion déchue. C'est comme l'homme le moins obscur qu'il sortait de la nuit, baigné dans la transparence par le privilège d'être au-dessus de toute interrogation, personnage transfiguré mais falot, d'où les problèmes maintenant s'écartaient, de la même manière qu'elle aussi se voyait détournée de lui par ce spectacle dramatiquement nul, détournée sur ellemême où il n'y avait ni richesse ni plénitude, mais l'appesantissement d'une morne satiété, la certitude que ne surviendrait pas d'autre drame que le déroulement d'un jour où se noyaient espoir et désespoir, l'inutile attente devenue, par suite de la suppression de tout but et du temps lui-même, une machine dont le mécanisme 
avait pour unique fonction de mesurer, dans une exploration silencieuse, le mouvement vide de ses diverses pièces. - (BLANCHOT, 2007, p. 77) ${ }^{65}$

Anne se depara com uma solidão "imensa". "Tudo que ela via, tudo isso que ela sentia era o dilaceramento que a separava do que ela via e sentia". O rompimento com o mundo e com o nexo das coisas, à altura do capítulo em questão, parece total para Anne, personagem que, como mencionamos, faz as vezes da obscuridade presente no fundo da obra de arte. O capítulo termina com Anne vendo nas relações humanas somente o reencontro com uma "aflição mortal".

No capítulo $\mathrm{X}$, encontramos Anne moribunda, "defendendo até o último instante seu direito à consciência e à sua parte de pensamentos claros". Anne não aceita entregar-se à morte "imaginária" para salvar-se da morte "verdadeira". Anne dorme, e sente "sua noite juntar-se à noite", "ela se descobria nesta grande noite exterior no mais íntimo dela mesma". Anne se cura no sono; vive certa alegria. É quando é tomada por um estado salutar repentino:

\begin{abstract}
Quelque chose qui était le prélude, non pas d'une guérison, mais d'un état surprenant de force, se glissa auprès d'elle. Personne ne comprenait qu'elle allait passer par l'état de santé parfaite, par un point merveilleusement équilibré de la vie, pendule qui allait d'un monde à un autre monde. Elle seule, à travers des nuées rapidement chassées au-dessus d'elle, à la vitesse d'une étoile, vit s'approcher ce moment où, reprenant contact avec la terre, elle ressaisirait l'existence banale, ne verrait rien, ne sentirait rien, où elle pourrait vivre, vivre enfin, et peut-être même mourir, épisode merveilleux. - (BLANCHOT, 2007, p.83) ${ }^{66}$
\end{abstract}

\footnotetext{
65 "Não somente todo motivo de uma comunicação clara estava destruído, mas à Anne parecia que o mistério deste ser havia se passado em seu próprio coração, lá mesmo onde ele não poderia ser discernido senão como uma questão eternamente mal colocada. E ele, pelo contrário, na silenciosa indiferença de sua vinda, aparecia com uma claridade ofensiva, sem o mais frágil, o mais tranquilizante índice de um segredo. Seria inútil para ela vê-lo com os olhares confusos de sua paixão decaída. É como o homem menos obscuro que ele saía da noite, banhado na transparência pelo privilégio de estar acima de toda interrogação, personagem transfigurado mas insignificante, de onde os problemas agora se distanciavam, da mesma maneira que ela também se via desviada dele por este espetáculo dramaticamente nulo, desviada dela mesma em que não havia nem riqueza nem plenitude, mas o pesar de uma morna saciedade, a certeza que não aconteceria outro drama que o desenrolar de um dia em que se misturariam esperança e desespero, a inútil espera tornada, pela série de uma supressão de todo fim e do tempo ele mesmo, uma máquina cujo mecanismo tinha por única função mesurar, em uma exploração silenciosa, o movimento vazio de suas diversas peças."

66 "Alguma coisa que era o prelúdio, não de uma cura, mas de um estado surpreendente de força, resvalou para perto dela. Ninguém compreendia que ela ia passar pelo estado de saúde perfeita, por um ponto maravilhosamente equilibrado da vida, pêndulo que ia de um mundo a outro mundo. Só ela, através de nuvens rapidamente perseguidas acima dela, à velocidade de uma estrela, viu aproximarse esse momento em que, retomando contato com a terra, retomaria a existência banal, não veria nada, não sentiria nada, onde poderia viver, viver enfim, e talvez mesmo morrer, episódio maravilhoso."
} 
Esse algo como um "prelúdio", que desliza - e a importância do deslizar foi assinalada por mais de um intérprete de Thomas l'obscur - e dá à Anne a impressão de que agora poderá viver, e mesmo morrer. Anne, a essa altura e em diversos momentos do texto, parece oscilar em relação à possibilidade da morte, morte essa que é hora possível, hora impossível. Anne sente enorme vivacidade, embora permaneça em repouso. Anne sente que vive, e viverá mais ainda se "pudesse eliminar as complacências e esperanças fáceis". Parece nada fazer, mas realiza um trabalho infinito. Fecha-se em "asilo de extremo silêncio". Aos poucos Anne se afasta das coisas do mundo. O cômodo por ela ocupado não é mais sequer habitável. "O mundo também estava devastado." As coisas mudam, e a mudança parece incomodar a Anne. Os seres à volta de Anne parecem exigir que deixe a vida, a alegria da vida, e dirija-se à morte definitiva. Tudo parece agora concorrer para esse fim, mas Anne continua a amar a vida, contrariando todos os elementos que se the opõem. Seus amigos sentem falta da degradação dos sentimentos própria aos moribundos, e praticamente exigem-na. Estranham a ausência de reciprocidade. Anne parece não concordar com a morte, a simples morte dos que pensam poder morrer. Guarda consigo suas maneiras habituais de ser, e não se deixa transfigurar pela morte iminente. Até o momento em que Anne cede: “(...) ela fez o sacrifício, sacrifício pleno de estranheza, de sua certeza de existir, para dar um sentido a este nada de amor que ela havia se tornado." Em busca do sentido, Anne se torna um ser diminuído de seu "tesouro mais íntimo", isto é, sua morte.

\footnotetext{
Durant les instants qui suivirent, une étrange cité s'éleva autour d'Anne. Elle ne ressemblait pas à une ville. II n'y avait là ni maison, ni palais, ni construction d'aucune sorte; c'était plutôt une immense mer, bien que les eaux en fussent invisibles et le rivage évanoui. - (BLANCHOT, 2007, p.93) ${ }^{67}$
}

Mais um, aqui, dos estranhos espaços, por vezes cidades inteiras, que soerguem em Blanchot em momentos curiosos da trajetória de cada narrativa. São espaços mormente "estranhos", dados a desaparecer em forma líquida, a transmutar-se em mares. Caso ousássemos julgar a ficção blanchotiana pelo que contém de paisagens e passagens marinhas, descobri-las-íamos mais evidentes até

\footnotetext{
67 "Durante os instantes que seguiram, uma estranha cidade se elevou em volta de Anne. Ela não se parecia com uma vila. Não havia aí nem casa, nem palácio, nem construção de sorte alguma; era sobretudo um imenso mar, embora as águas nele fossem invisíveis e a margem esvanecida."
} 
que as passagens noturnas, onde sobressaem a primeira, a segunda, a última noites. Aqui, no caso, com Anne já entregue à vontade de sua comunidade: morrer a morte monumental, a morte que se realiza, a morte definitiva: o fim da morte. Mas a experiência de Anne - já em 1941, segundo a relação entre morte e literatura vislumbrada por Blanchot, e que apareceria em outros formatos na ensaística da década de 1950 - é outra, como a descrição do espaço incomum de uma cidade parece sugerir: nessa cidade "distante de todas as coisas", nas "perspectivas de um estranho horizonte", algo que não pode se representar se mostra a Anne: "não mais um ser humano, mas somente ser, maravilhosamente ser, entre os efêmeros e os sóis declinantes (...)". São o que o narrador chama de "ecos prolongados dessa enorme noite" que figuram agora diante de Anne. A passagem em que surgem esses seres absurdos é das mais reveladoras, e talvez mais próximas da ensaística de Blanchot, da época e posterior:

\begin{abstract}
Ce qu'étaient ces formes, êtres, entités funestes, cela ne saurait être dit, car, pour nous, au sein du jour quelque chose peut-il apparaître qui ne serait pas le jour, quelque chose qui dans une atmosphère de lumière et de limpidité représenterait le frisson d'effroi d'où le jour est sorti? Mais eux, insidieusement, se firent reconnaître, au seuil de l'irrémédiable, comme les lois obscures appelées à disparaître avec Anne. Que résulta-t-il de cette révélation? On eût dit que tout était détruit, mais que tout aussi recommençait. Le temps, sortant de ses lacs, la fit rouler dans un passé immense et, quoiqu'elle ne pût tout à fait quitter l'espace où elle respirait encore, l'attira jusqu'à d'insondables vallées où le monde semblait revenu au moment de sa création. La vie d'Anne - et ce mot même résonnait dans ce milieu où il n'y avait pas de vie comme un défi - participa au premier rayon jeté de toute éternité au milieu des notions indolentes. Les forces vivifiantes la baignèrent, comme si elles avaient trouvé brusquement, dans son sein voué à la mort, le sens en vain cherché du mot vivifiant. Le caprice, qui échafaudait l'infinité de ses combinaisons pour conjurer le vide, la saisit, et si elle ne perdit pas alors toute existence, son malaise fut pire, son changement plus grand que si, réellement, dans son tranquille état humain, elle avait abandonné la vie, car il n'y eut pas d'absurdités auxquelles elle échappât et elle devint, pendant l'intervalle d'un temps simulé par la fusion de l'éternité et de l'idée de néant, tous les monstres dans lesquels la création s'essayait vainement. - (BLANCHOT, 2007, p. 94) ${ }^{68}$
\end{abstract}

\footnotetext{
68 "O que eram essas formas, seres, entidades funestas, isso não poderia ser dito, pois, para nós, no seio do dia alguma coisa pode aparecer que não seria o dia, alguma coisa que numa atmosfera de luz e limpidez representaria o tremor de pavor de onde o dia saiu? Mas eles, insidiosamente, fizeramse reconhecer, no limiar do irremediável, como que as luzes obscuras chamadas a desaparecer com Anne. Que resultou dessa revelação? Ter-se-ia dito que tudo estava destruído, mas que tudo também recomeçava. O tempo, saindo de seus lagos, fê-la rolar num passado imenso e, ainda que ela não tenha podido inteiramente abandonar o espaço onde ainda respirava, a atraiu a vales insondáveis onde o mundo parecia retornado ao momento de sua criação. A vida de Anne - e essa palavra mesma ressoava nesse meio em que não havia vida como um desafio - participou no primeiro raio jogado de toda eternidade no meio das noções indolentes. As forças vivificantes banharam-na, como se elas houvessem encontrado bruscamente, em seu seio votado à morte, o sentido em vão buscado da palavra vivificante. O capricho, que elaborava a infinidade de suas combinações para conjurar o vazio, a capturou, e se ela não perdia então toda a existência, seu desconforto foi pior, sua mudança maior que se, realmente, em seu tranquilo estado humano, tivesse abandonado a vida, pois não
} 
Toda a descrição acima, com seu barroquismo já diminuído da passagem do roman ao récit Thomas l'Obscur, retrata o instante em que tudo é destruído, mas que tudo recomeça - como, de resto, a maioria dos escritos de Blanchot parece implicar. Anne participa desse momento apoteótico, muito mais difícil do que se houvesse simplesmente morrido ou abandonado a vida, e vem a tornar-se, "durante o intervalo de um tempo simulado pela fusão da eternidade e da ideia de vazio, todos os monstros nos quais a criação se ensaiava em vão." Nesse intervalo do tempo, nesse encontro do vazio com a eternidade em que seres infiguráveis e indeterminados irrompem no interstício, é aí que Anne vê saturar-se a possibilidade da morte humana, do fim do morrer, e assiste do alto da metrópole insólita do sentido ao fim da própria possibilidade do findar. Após isso, "isso que de maneira alguma poderia ser atingido recebeu de uma mão misteriosa seu êxito", isto é, o inaudito toma lugar. Mas pessoa nenhuma em volta de Anne se dá conta do que aconteceu com ela, embora a atmosfera houvesse se alterado de modo grave. Mesmo o médico deixa de perceber, imaginando-a uma moribunda comum, que ela "havia já chegado ao instante em que nela as leis morriam". Ao instante, enfim, "em que a morte, destruindo tudo, podia também destruir a possibilidade do aniquilamento." Anne finge observar os ritos de moribunda, finge amar seus próximos, seus inimigos, finge necessitar de perdão. Torna-se mais e mais invisível, como sugere o protocolo dos vivos. Seu olhar se esvazia. O capítulo termina com a seguinte frase:

Elle entendait aussi Thomas; justement, elle savait maintenant ce qu'il fallait dire à Thomas, elle connaissait exactement les mots que toute sa vie elle avait cherchés pour l'atteindre. Mais elle se taisait, elle pensait : à quoi bon - ce mot aussi était le mot qu'elle cherchait —, Thomas est insignifiant. Dormons. - (BLANCHOT, 2007, p. 96) ${ }^{69}$

No próximo capítulo, Anne está morta. Thomas fala, sozinho, algo que "de modo algum poderia ser lido". Thomas insiste, no entanto, em falar, "como se seus pensamentos houvessem tido alguma chance de ser entendidos, e deixou de lado a verdade estranha à qual parecia acorrentado." Anne não parece mudada. Seu rosto,

houve absurdos aos quais ela escapasse e ela tornou-se, durante o intervalo do tempo simulado pela fusão da eternidade e da ideia de nada, todos os monstros nos quais a criação se ensaiava em vão." 69 "Ela escutava também Thomas; justamente, ela sabia agora o que era necessário dizer a Thomas, conhecia exatamente as palavras que toda sua vida ela tinha buscado para atingi-lo. Mas ela se calava, pensava: para que [à quoi bon] - essa palavra era a palavra que ela buscava - Thomas é insignificante. Durmamos." 
no entanto, "confunde os olhares". Parece mesmo ser mais Anne do que fora outrora, viva: "(...) tudo isso que a impedia de ser distinguida de uma pesso a real, era isso que verificava seu aniquilamento. Ela era inteira em si: na morte, abundante de vida. Ela tinha o ar mais grave, mais mestre dela mesma. Nenhuma Anne faltava ao cadáver de Anne. (...)" Então Blanchot descreve Anne em termos de todo análogos aos do ensaio sobre as relações entre a ontologia da imagem e a ontologia do cadáver publicado em 1951 e após isso reunido em L'espace littéraire (em 1955), intitulado "Les deux versions de l'imaginaire", que analisaremos a seguir:

Dans sa fin, elle semblait avoir besoin de plus d'être pour être anéantie que pour être et, morte justement de ce surcroît qui lui permettait de se montrer tout entière, elle donnait à la mort toute la réalité et toute l'existence qui formaient la preuve de son propre néant. Non pas impalpable ni dissoute dans les ombres, elle s'imposait aux sens toujours davantage. A mesure que sa mort devenait plus réelle, elle grandissait, elle grossissait, elle creusait dans sa couche un profond tombeau. Elle attirait, elle si effacée, tous les regards. Nous qui demeurions auprès d'elle, nous nous sentions comprimés par cet être de grand format. Nous étouffions, privés d'air. Ce que seuls les porteurs de cercueil peuvent savoir, que les morts doublent de poids, que ce sont les plus grands, les plus forts de tous les êtres, chacun I découvrait avec angoisse. Chacun portait sa part de ce mort évident." (BLANCHOT, 2007, p. 101) ${ }^{70}$

A realidade da morte ganha com a atitude insólita de Anne, que se impõe mais e mais aos sentidos de quem a perscruta. O seu cadáver cresce, e esse crescimento é fonte de atração, fascinação do olhar de outrem, ao ponto de causar asfixia. Morrendo, ela dava ao nada um corpo, dava a "forma de alguma coisa" ao nada. Como no ensaio mencionado, em que Blanchot comparava a estranheza da imagem à estranheza do cadáver, argumentando que isso a que se dá o nome de "restos mortais" escapa às categorias comuns do pensamento, pois se trata de algo que "está aí diante de nós, que não é nem o vivo em pessoa, nem uma realidade qualquer, nem o mesmo que aquele que era em vida, nem um outro, nem outra coisa. Isso que está ali, na calma absoluta do que encontrou seu lugar, não realiza,

\footnotetext{
70 "Em seu fim, ela parecia ter necessidade de mais ser para ser nadificada que para ser e, morta justamente deste suplemento que Ihe permitia se mostrar inteiramente, ela dava à morte toda a realidade e toda a existência que formavam a prova de seu próprio nada. Nem impalpável nem dissoluta nas sombras, ela impunha-se sempre mais aos sentidos. À medida que sua morte tornavase mais real, ela crescia, engordava, cavava em seu jazigo uma tumba profunda. Ela atraia, ela tão apagada, todos os olhares. Nós que permanecíamos perto dela, nós sentíamo-nos comprimidos por este ser de grande formato. Nós sufocávamos, privados de ar. Isso que só os portadores de féretro podem saber, que os mortos dobram de peso, que esses são os mais pesados, os mais robustos de todos os seres, cada um o descobria com angústia. Cada um portava sua parte deste morto evidente."
} 
no entanto, a verdade de estar plenamente aqui. A morte suspende a relação com o lugar, embora o morto nele se apoie gravemente como à única base que Ihe resta." (BLANCHOT, 1955, p. 268-269. Grifo nosso). Suspensão do lugar, que é sobretudo suspensão do sentido. E o movimento da morte ao sentido é construído desde o primeiro romance de Blanchot, como podemos notar: "a presença cadavérica estabelece uma relação entre aqui e parte alguma". Prossigamos com a leitura da narrativa em questão.

Anne dá voz ao silêncio, e seu rosto, "cada vez mais belo", auxilia a constituir sua ausência. “(...) Nenhuma parte dela que fosse ainda o sustentáculo de uma realidade qualquer". Então acontece, e talvez seja um dos centros - imaginários, a crer na terminologia empregada no prefácio de Blanchot à segunda versão do livro do que poderíamos chamar a epifania de Thomas: o momento em que sua experiência órfica com Anne leva-o a transfigurar sua própria (talvez mais exato seria dizê-la imprópria) experiência da morte. Citamos a passagem inteira, dada sua importância no contexto geral da narrativa:

(...) C'est alors, son histoire et l'histoire de sa mort s'étant évanouies ensemble et plus personne n'étant au monde pour nommer Anne, qu'elle atteignit le moment d'immortalité du néant où ce qui a cessé d'être entre dans un rêve sans pensée. C'était vraiment la nuit. Je fus environné d'astres. La totalité des choses m'enveloppa et je me préparai à l'agonie par la conscience exaltée de ne pouvoir mourir. Mais, à cet instant, ce qu'elle seule jusqu'ici avait entrevu apparut manifeste à tous : je leur révélai, en moi, l'étrangeté de leur condition et la honte d'une existence interminable. Assurément, je pouvais mourir, mais la mort perfidement brillait pour moi comme la mort de la mort, de sorte que, devenant l'homme éternel qui prend la place du moribond, cet homme sans crime, sans raison de mourir qu'est tout homme qui meurt, je mourais, mort si étranger à la mort, que je passais mon instant suprême dans un temps où il n'était déjà plus possible de mourir et que je vivais cependant toutes les heures de ma vie à l'heure où je ne pouvais plus les vivre. Qui, plus que moi, fut chassé de la dernière minute pleine d'espoir, à ce point privé de la dernière consolation que le souvenir offre aux désespérés, à ceux qui ont justement oublié le bonheur et se jettent du haut de la vie pour s'en rappeler les joies? Et cependant, j'étais vraiment un mort, j'étais même le seul mort possible, j'étais le seul homme qui ne donnât pas l'impression de mourir par hasard. Toute ma force, le sentiment que j'avais d'être, en prenant de la ciguë, non pas Socrate mourant, mais Socrate s'augmentant de Platon, cette certitude de ne pouvoir disparaître qu'ont seuls les êtres frappés d'une maladie mortelle, cette sérénité devant l'échafaud qui donne aux condamnés leur vraie grâce, faisait de chaque instant de ma vie l'instant où j'allais quitter la vie. Tout mon être parut se confondre avec la mort. Aussi naturellement que les hommes croient vivre, acceptant comme un mouvement inévitable la succession du souffle et le retour du sang, je cessai de vivre. Je tirai ma mort de mon existence même et non de l'absence de l'existence. - (BLANCHOT, 2007, p. 104) ${ }^{71}$

\footnotetext{
71 "Foi então, sua história e a história de sua morte desvanecidas juntas e mais pessoa alguma estando no mundo para nomear Anne, que ela atingiu o momento de imortalidade do nada onde isso que cessou de ser entra em um sonho sem pensamento. Era verdadeiramente a noite. Eu fui cercado de astros. A totalidade das coisas me envolveu e eu me preparava para agonia pela consciência
} 
Agora temos Thomas, uma vez mais envolto pela noite. Mas os astros, agora, trazem com eles a certeza da impossibilidade da morte. "Eu Ihes revelava, em mim, a estranheza da sua condição e a vergonha de uma existência interminável". É importante que guardemos a frase citada, especialmente o vocábulo "vergonha". Ele aparece novamente ao final do livro, e guarda uma analogia precisa com a estrutura que identificamos na obra de Blanchot, objeto do presente trabalho. Cada instante da vida de Thomas, doravante, será o instante em que ele irá abandonar a vida. Seu ser, agora, confunde-se com o ser da morte: esse é o resultado da pedagogia mortal de Anne. A morte (a arte?) e o sentido que ela garante para ele agora retiram-se da existência, e não da ausência de existência.

Thomas se questiona quanto ao que o distingue dos vivos. A distinção é exatamente uma das figurações da questão do sentido na obra de Blanchot: "nem noite" e nem "perda de consciência" são o que aguarda o morto. Thomas desacredita a pessoalidade de um ato que exige que encontre "o sentido e a explicação definitiva de minha morte". Necessário sublinhar a ambiguidade do primeiro sentido da frase: "encontrar o sentido e a explicação definitiva de minha morte" é uma frase distinta de "encontrar o sentido e a explicação definitiva de minha morte", embora a diferença se inscreva de maneira algo sutil; impossível portanto não somente encontrar o sentido, mas também encontrar o sentido da morte - e sua explicação definitiva ${ }^{72}$. Uma das mais ricas passagens do livro, a nosso ver, se

exaltada de não poder morrer. Mas, neste instante, isso que ela somente havia até então entrevisto apareceu manifesto a todos: eu lhes revelava, em mim, a estranheza de sua condição e a vergonha de uma existência interminável. Certamente, eu podia morrer, mas a morte brilhava perfidamente para mim como a morte da morte, de sorte que, tornando-me o homem eterno que toma o lugar do moribundo, esse homem sem crime, sem razão de morrer que é todo homem que morre, eu morria, morto tão estranho à morte, que eu passava meu instante supremo em um tempo onde não era mais possível morrer e que eu vivia no entanto todas as horas de minha vida na hora em que eu não podia mais vivê-las. Quem, mais que eu, foi caçado do último minuto pleno de esperança, a esse ponto privado da última consolação que a lembrança oferece aos desesperados, a esses que justamente esqueceram a felicidade e se lançam do alto da vida para se recordar das alegrias? E todavia eu era verdadeiramente um morto, eu era mesmo o único morto possível, eu era o único homem que não dava a impressão de morrer por acaso. Toda minha força, o sentimento que tinha de ser, tomando a cicuta, não o Sócrates moribundo, mas Sócrates engrandecendo-se de Platão, esta certeza de não poder desaparecer que têm somente os seres golpeados de uma doença mortal, esta serenidade diante do cadafalso que dá aos condenados a sua verdadeira graça, fazia de cada instante de minha vida o instante em que eu ia abandonar a vida. Todo meu ser pareceu confundir-se com a morte. Tão naturalmente como os homens creem viver, aceitando como um movimento inevitável a sucessão do sopro e o retorno do sangue, eu cessava de viver. Eu retirava minha morte de minha existência mesma e não da ausência de existência."

${ }^{72}$ Esse tipo de ambiguidade é patente na obra ficcional e crítica de Blanchot, e irrompe, em suas ficções, em momentos decisivos - cujo registro e análise, como foi mencionado, é um dos propósitos da presente tese. 
podemos aqui fazer um juízo estético, é a contida nas palavras a seguir, em que se mostra, uma vez mais, a obscuridade inteira do personagem que dá nome ao livro:

Sous le nom de Thomas, dans cet état choisi où l'on pouvait me nommer et me décrire, j'avais l'aspect d'un vivant quelconque, mais comme je n'étais réel que sous le nom de mort, je laissai transparaître, sang mêlé à mon sang, l'esprit funeste des ombres, et le miroir de chacun de mes jours refléta les images confondues de la mort et de la vie. Ainsi mon sort stupéfia les foules. Ce Thomas me força à paraître, tout en étant vivant, non pas même le mort éternel que j'étais et sur lequel personne ne pouvait poser les regards, mais un mort ordinaire, corps sans vie, sensibilité insensible, pensée sans pensée. Au plus haut point de la contrariété, je fus ce mort illégitime. Représenté en mes sentiments par un double pour qui chaque sentiment signifiait autant d'absurdité que pour un mort, j'atteignis, au comble de la passion, le comble de l'étrangeté et je parus ravi à la condition humaine pour l'avoir accomplie vraiment. Étant, dans chaque acte humain, le mort qui à la fois le rend possible et impossible et, si je marchais, si je pensais, celui dont la complète absence permet seule le pas et la pensée, en face des bêtes, êtres qui ne portent pas en eux leur double mort, je perdis ma dernière raison d'être. II y eut entre nous un tragique intervalle. Je cessai, homme sans aucune parcelle d'animalité, avec ma voix qui ne chantait plus, qui ne parlait même plus comme celle de l'oiseau parleur, de pouvoir m'exprimer. Je pensais, en dehors de toute image et de toute pensée, dans un acte qui consistait à être impensable. A tout instant, j'étais cet homme purement humain, individu suprême en unique exemplaire, contre lequel, au moment de mourir, chacun s'échange et qui meurt seul à la place de tous. - (BLANCHOT, 2007, p. 106 ${ }^{73}$

Thomas, agora, vive o espelho que "refletiu as imagens confundidas da morte e da vida". É o morto que permite que cada "ato humano" seja a um só tempo possível e impossível, espécie de simulacro, aparentemente, pela "reação" de Thomas, que erige entre ele e os vivos "um trágico intervalo". Então Thomas perde o poder de expressar-se. "(...) Eu pensava, fora de toda imagem e de todo pensamento, em um ato que consistia em ser impensável." Esse Thomas obscuro

\footnotetext{
73 "Sob o nome de Thomas, neste estado escolhido em que podia-se nomear-me e descrever-me, eu tinha o aspecto de um vivente qualquer, mas como eu não era real senão sob o nome de morte, eu deixava transparecer, sangue misturado a meu sangue, o espírito funesto das sombras, e o espelho de cada um de meus dias refletiu as imagens confundidas da morte e da vida. Assim minha sorte supreendeu as massas. Esse Thomas forçou-me a aparecer, estando vivo, não mesmo o morto eterno que eu era e sobre o qual ninguém podia pousar os olhares, mas um morto ordinário, corpo sem vida, sensibilidade insensível, pensamento sem pensamento. No mais alto ponto da contrariedade, eu fui esse morto ilegítimo. Representado em meus sentimentos por um duplo para o qual cada sentimento significava tanto absurdo quanto para um morto, eu atingi, no cúmulo da paixão, o cúmulo da estranheza e pareci encantado com a condição humana por tê-la verdadeiramente compreendido. Sendo, em cada ato humano, a morte que ao mesmo tempo torna-o possível e impossível e, se eu andava, se eu pensava, aquele cuja completa ausência permite somente o passo e o pensamento, em face das bestas, seres que não portam neles sua dupla morte, perdi minha última razão de ser. Houve entre nós um trágico intervalo. Eu cessava, homem sem parcela alguma de animalidade, com minha voz que não cantava mais, que não falava mesmo como aquela do pássaro falante, de poder me expressar. Eu pensava, fora de toda imagem e de todo pensamento, em um ato que consistia em ser impensável. A todo instante, eu era esse homem puramente humano, indivíduo supremo e único exemplar, contra o qual, no momento de morrer, cada um se permuta e que morre só no lugar de todos."
} 
torna-se paulatinamente uma figura messiânica paradoxal: embora os homens não reconheçam sua presença, fraquejam diante do vazio representado por Thomas, diante da tentação dessa figura morta e rediviva, desta figura messiânica, preferindo o vazio dessa realidade irreal à qualquer possibilidade de existência: "Então abriam as portas da agonia e se precipitavam em seu erro." "Eles não amavam senão a vida e lutavam contra ela". Esses homens errantes perecem pela própria vontade de viver, e quando crêem fugir à morte, se lançam desbragadamente a seu encontro. Thomas transforma os homens. Nova ocorrência, nesse momento, da palavra "sens" (sentido): “(...) e a amiga a mais adorável, o melhor filho, diante desta forma estrangeira, viam seu sentido se alterar e, a isso que mais amavam, lançavam um olhar de horror". As relações entre os homens também se alteram como consequência da parada de Thomas. Por fim, acabam por se assemelhar aos mortos, e esses "retornam triunfalmente à existência". "É em um mundo harmonioso que cada um continua a viver, imortal até o fim". A "turba" - é com essa imprecisão que o narrador determina os outros que se relacionam a Thomas - tem duas certezas que se anulam: a de morrer e a de não morrer. Thomas então se compara aos homens, numa questão que retornará em diversos momentos na ficção de Blanchot: o dia.

\begin{abstract}
Voyez les hommes: le vide pur somme leur oeil de se dire aveugle, et un perpétuel alibi entre la nuit du dehors et la nuit du dedans leur permet toute la vie l'illusion du jour. Pour moi, c'est cette illusion qui par un coup inexplicable sembla être sortie de moi-même. Je me trouvai avec deux visages collés l'un contre l'autre. Je ne cessai de toucher à deux rivages. (...) Ayant deux yeux dont l'un d'une extrême acuité de vision, c'est avec celui qui n'était oeil que par son refus de voir que je voyais tout ce qui était visible. Et ainsi pour tous mes organes. J'eus de moi une partie immergée, et c'est à cette partie perdue dans un constant naufrage que je dus ma direction, ma figure et ma nécessité. Je trouvai ma preuve dans ce mouvement vers l'inexistant où, au lieu de se dégrader, la preuve que j'existais se renforçait jusqu'à l'évidence. - (BLANCHOT, 2007, p. 111) ${ }^{74}$
\end{abstract}

De modo radicalmente distinto dos outros homens, esses que vivem nesse "álibi perpétuo entre a noite do fora e a noite do dentro" que thes

\footnotetext{
74 "Veja os homens: o vazio puro intima seu olho a se dizer cego, e um perpétuo álibi entre a noite do fora e a noite do dentro lhes permite toda a vida a ilusão do dia. Para mim, é essa ilusão que por um golpe inexplicável parece saída dela mesma. Eu me encontrei com dois rostos colados um ao outro. Não cessei de tocar as duas margens. (...) Tendo dois olhos, um de uma extrema acuidade de visão, era com ele, que não era olho senão por sua recusa em ver, que eu via tudo isso que era visível. $E$ assim para todos meus orgãos. Tive de mim uma parte imersa, e é a essa parte perdida em um constante naufrágio que eu devia minha direção, minha figura e minha necessidade. Encontrava minha prova nesse movimento em direção ao inexistente em que, no lugar de se degradar, a prova de que eu existia se reforçava até a evidência."
} 
permete durante a extensão de suas vidas a "ilusão do dia", Thomas tem parte com esse "naufrágio constante", que mantém parte sua obscura de modo permanente: é daí que vem sua "direção, (...) figura, (...) necessidade". Move-se obstinadamente em direção ao "inexistente". A despeito de seus esforços, Thomas não consegue atingir esse outro que seria seu eu em permanência, o outro que é ele mesmo e que no entanto the é infinitamente alheio, simulacro de si, refração inexorável de seu estado obscuro. Distância intransponível entre Thomas cadáver, "vivente sem vida", e Thomas amortal - incapaz de findar - que extravia o personagem e seu esforço contínuo para unir as duas figuras, certamente fruto da experiência órfica com Anne. "Nenhuma poção para unir-me a isso que não podia suportar nome, nem ser designado pelo contrário de seu contrário, nem concebido como uma relação ao que quer que fosse.". A morte é muito menos que Thomas, é tão somente uma "metamorfose grosseira" diante da "nulidade indiscernível" que era o nome de Thomas. "Era isso, então, uma quimera, este enigma, obra de uma palavra formada de modo maligno para destruir todas as palavras?" (aqui temos talvez uma sugestão do que o nome Thomas significa na narrativa de Blanchot. Lembre-se da etimologia do nome: Thomas significa gêmeo, gêmeo esse que, de certa forma, esgarça os limites da univocidade do sujeito; e no Novo Testamento, Thomas é o nome do apóstolo que duvida da existência do cristo ressuscitado, apostasia da presença indubitável do cristo). Thomas não consegue avançar sobre ou em direção a Thomas simulacro, a Thomas obscuro, a Thomas-nome. "Se avançava em mim mesmo, apressando-me com grande esforço em direção a meu exato meio dia, experimentava, como uma trágica certeza, no centro de Thomas vivente, a proximidade inacessível deste Thomas nada, e quanto mais a sombra de meu pensamento diminuía, mais eu me concebia, nesta claridade sem falha, como o hóspede possível e pleno de desejos deste obscuro Thomas. Na plenitude de minha realidade, eu cria tocar o irreal." Então, a essa altura do penúltimo capítulo do récit, encontramos a frase emblemática, quando o narrador novamente - Thomas, aparentemente, nesse momento - se encontra em uma cavidade, uma "grota profunda": 
j'écrivais sur le mur ces douces paroles : 'Je pense, donc je ne suis pas.' (BLANCHOT, 2007, p. 114) ${ }^{75}$

"Penso, logo não sou", diz Thomas, ou ao menos o Thomas-simulacro que se apresenta diante de Thomas. "Eu penso, dizia ele, eu reuni tudo isso que é luz sem calor, fagulha sem brilho, produtos não refinados, eu os abraço e conjugo e, numa primeira ausência de mim mesmo, eu me descubro no seio da mais viva intensidade como uma unidade perfeita. Eu penso, diz ele, eu sou sujeito e objeto de uma irradiação toda-poderosa; sol que emprega toda sua energia tanto em se fazer noite como em se fazer sol. Eu penso: aí onde o pensamento se junta a mim, eu, eu posso me subtrair do ser, sem diminuição nem mudança, por uma metamorfose que me conserva a mim mesmo fora de todo anteparo a me discernir. É a propriedade de meu pensamento, não de assegurar-me a existência, como todas as coisas, como a pedra, mas assegurar-me do ser no nada mesmo e de me convir não ser mais para então fazer-me sentir minha admirável ausência. Eu penso, diz Thomas, e esse Thomas invisível, inexprimível, inexistente que eu tornei-me fez com que doravante eu jamais estivesse aí onde estava, e com que não houvesse nada de misterioso nisso. Minha existência se tornou aquela de um ausente que, a cada ato que realizava, produzia o mesmo ato não o realizando." É já o discurso de Thomas transformado, Thomas-escritor, que traça diante do vazio traços que se desfazem tão logo inscritos. Esse Thomas ausente, algo hegeliano, como se pode notar na descrição acima, marca um dos momentos na oscilação filosófica do personagem: assegura-se da morte, faz dela uma potência. Mas então ocorre-lhe que pensar é não ser, mas sim a ausência infinita (que não é outro nome para o ser). Thomas vê uma mulher, não se sabe se o simulacro de Anne ou seu próprio simulacro, seu próprio gêmeo. Essa mulher experimenta Thomas como algo absurdo, trazendo-Ihe a experiência do "único mistério verdadeiro", isto é, a ausência de mistério, "que ela não podia então senão procurar eternamente." A paz, então, torna-se sufocante para Thomas. Ele se questiona se é a noite que chega (a chegada da noite e do dia são cenas e problemas recorrentes em Blanchot, como teremos a oportunidade de notar). Há momentos em que ainda sucumbe, aparentemente, ao desejo de uma "simples morte em uma agonia em que se estilhaçaria." Thomas perde a noção de

\footnotetext{
75 "É então que no seio de uma grota profunda a loucura do pensador taciturno me apareceu, e palavras ininteligíveis ressoaram a minhas orelhas, enquanto eu escrevia sobre o muro essas doces palavras: 'Eu penso, logo não sou."”
} 
um "horizonte": nadifica-se absolutamente. O restante do monólogo é dedicado a frases como essa, em que define a noite em termos muito semelhantes ao de escritos futuros:

\begin{abstract}
Tous les sentiments rejaillissent hors d'eux-mêmes et convergent, détruits, abolis, vers ce sentiment qui me pétrit, me fait et me défait et me fait affreusement sentir, dans une totale absence de sentiment, ma réalité sous la forme du néant. Sentiment qu'il faut bien nommer et que j'appelle l'angoisse. Voilà donc la nuit. L'obscurité ne cache aucune chose. Mon premier discernement est que cette nuit n'est pas l'absence provisoire de la clarté. Loin d'être un lieu possible d'images, elle se compose de tout ce qui ne se voit pas et ne s'entend pas et, en l'écoutant, même un homme saurait que, s'il n'était pas homme, il n'entendrait rien. A la vraie nuit manquent donc l'inouii, l'invisible, tout ce qui peut rendre la nuit habitable. Elle ne se laisse rien attribuer d'autre qu'elle, elle est impénétrable. Je me trouve vraiment dans l'au-delà, si l'au-delà, c'est ce qui n'admet pas d'au-delà. (BLANCHOT, 2007, p. 123) ${ }^{76}$
\end{abstract}

\title{
"À verdadeira noite faltam o inusitado, o invisível, tudo isso que pode tornar a
} noite habitável". Eis aqui o que Blanchot chamará de "segunda noite" no livro L'Espace littéraire, esse espaço em que nada se estende, "hors du temps" em que o tempo não passa, distinta de todo da noite romântica, inspiração de mundos literários personalistas. Thomas avança nessa noite, "portando o todo", em direção "ao que excede infinitamente o todo". Parece tornar-se onipotente: "comigo gravitam fora das leis as leis, fora do possível o possível". "Oh noite, agora nada me fazerá ser, nada me separará de ti." Thomas crê nomear, definir a noite, ajuntar-lhe uma consciência: dominá-la. Crê trazer à noite a consciência de sua própria aridez. "Eu sou contigo, como se tu fosses minha obra. Minha obra... Que luz estranha cai sobre mim?" Thomas crê, a essa altura, aproximar-se da coisa órfica. "Isso que nunca teve princípio me admite em seu eterno começo, eu que sou a recusa de meu próprio começo. Eu sou a origem disso que é sem origem. Eu criei o que não podia ser criado."

Assim termina o penúltimo capítulo de Thomas l'obscur: uma espécie de hino órfico à segunda noite. $\mathrm{O}$ último capítulo dessa narrativa realmente - como pode

\footnotetext{
76 "Todos os sentimentos jorravam para fora deles mesmos e convergiam, destruídos, abolidos, em direção a esse sentimento que me petrifica, me faz e me desfaz e me faz sentir terrivelmente, em uma total ausência de sentimento, minha realidade sob a forma do nada. Sentimento que é bem necessário nomear e que eu chamo de angústia. Eis então a noite. A obscuridade não esconde coisa alguma. Meu primeiro discernimento é que essa noite não é a ausência provisória da claridade. Longe de ser um lugar possível de imagens, ela se compõe de tudo isso que não se vê e não se escuta e, escutando, mesmo um homem saberia que, se não fosse homem, não escutaria nada. À verdadeira noite faltam portanto o insólito, o invisível, tudo isso que pode tornar a noite habitável. Ela não se deixa nada atribuir de outro que ela, é impenetrável. Eu me encontro verdadeiramente além, se além é isso que não admite além."
} 
parecer agora, de fato, ao leitor - impassível da confecção de um sumário encontra Thomas avançando sobre o campo, notando a primavera que se aproxima, prelúdio, talvez, do fim da narrativa, que também se aproxima. "Todos se agitam para receber o reflexo das novas flamas", e a percepção geral - desses outros que permanecem indeterminados no decorrer do capítulo - é a de uma embriaguez infinita, é a de que a vida duraria para sempre. "Através dos campos se estendia o ideal da cor. Através do céu transparente e vazio se estendia o ideal da luz." A primavera envolve Thomas como a noite o envolvia alguns capítulos atrás. A natureza toda transborda de felicidade e plenitude. O mar, imenso, estende-se novamente a seus pés. É uma descrição viva de um mundo em transe, suspenso, a que esse capítulo nos traz. "Pássaros ternos, desenhados para ser o conservatório da música sem notas, cantavam a ausência de canto." Thomas avança em direção à cidade (outra cidade decisiva nas descrições da narrativa de Blanchot, talvez?). Não há barulho ou silêncio. Há casas enormes, desertas, e pessoa alguma nas ruas. "Imensas cidades não edificadas", diz o narrador. Os edifícios erguem-se como astros, "tocando-os, para destruí-los, os mundos invisíveis." Há menção a sóis que não brilham mais ${ }^{77}$. Thomas permanece avançando: conduz a "tropa de constelações, a maré dos homens-estrela em direção à primeira noite". Os homens descritos creem poder um dia reviver no mundo em que outrora viveram, soerguer novamente o sentido que habitaram outrora. Mas o esquecimento sobrevém sua monumental memória. A única coisa de que se lembram de suas linguagens é a palavra vazia - e a dar crédito à etimologia, "gêmeo", vazia inclusive de si mesma - de Thomas.

On les vit bondir désespérément hors de leur enceinte, flotter, glisser
sournoisement, mais alors qu'ils croyaient déjà voler au triomphe, essayant de
composer avec l'absence de pensée une pensée plus forte qui dévorerait lois,
théorèmes, sagesse, le gardien de l'impossible les saisit, et ils s'abîmèrent dans le
naufrage. Chute prolongée, pesante : étaient-ils parvenus, comme ils le rêvaient,
aux confins de l'âme qu'ils croyaient parcourir? Lentement ils sortirent de ce rêve
et trouvèrent une solitude si grande que, les monstres avec lesquels on les avait
effrayés quand ils étaient hommes s'étant approchés d'eux, ils les regardèrent 77 Esta imagem é recorrente na ensaística e na ficção de Blanchot, e poderíamos fazer a genealogia
das imagens com que Blanchot buscou potencializar e paralisar o sentido e a linguagem:
primeiramente o mar - como em Thomas l'obscur, ou em alguns ensaios de Le livre à venir - e
posteriormente as estrelas, ou, mais precisamente, essa figura do astro obscuro que não brilha e,
portanto, não é mais capaz de orientar o navegante. Ambas figurações formam um só quadro, e à
imagem do mar contrapõe-se a imagem de um céu de estrelas obscuras, de astros que queimam em
sua obscuridade. Tentamos cartografar essas imagens, na literatura de Blanchot e em outras, em
uma apresentação no IV Seminário do Grupo Escritura: Linguagem e Pensamento ("Cada vez, o
impossível - Derrida dez anos depois"), intitulada "Ás bordas da ficção - A paisagem marinha em
'Thomas l'Obscur' de Maurice Blanchot a partir de Jacques Derrida". 
avec indifférence, ne virent rien et, se penchant sur la crypte, demeurèrent là, dans une profonde inertie, à attendre mystérieusement que la langue dont chaque prophète, au fond de sa gorge, a senti la naissance, sortît de la mer et leur poussât dans la bouche les mots impossibles. Cette attente, vapeur funeste, exhalée goutte à goutte du sommet d'une montagne, il semblait qu'elle ne pourrait avoir de fin. Mais, quand réellement du fond des ténèbres s'éleva un cri prolongé qui était comme la fin d'un rêve, tous reconnurent l'océan et ils aperçurent un regard dont l'immensité et la douceur éveillèrent en eux des désirs qu'ils ne purent supporter. Pour un instant redevenus des hommes, ils virent dans l'infini une image dont ils jouissaient et, cédant à une dernière tentation, ils se dénudèrent voluptueusement dans l'eau. - (BLANCHOT, 2007, p. 137) ${ }^{78}$

Uma vez mais, levados pelo "guardião do impossível", Thomas, os homens desistem de seus sonhos de vivência e afundam - junto com Thomas - novamente no abismo do mar, no naufrágio infinito da linguagem. Ouve-se um "grito prolongado", "como o fim de um sonho", e os homens deslizam à espuma do mar. Thomas, então, "olhou essa vaga de imagens grosseiras", e quando chega sua vez, se joga de modo desesperado e triste no mar, "como se a vergonha houvesse começado por ele.". No momento de sua segunda dissolução, Thomas sente vergonha; No momento do fim, ou no que deveria ser o momento do fim, talvez fosse mais exato dizer, Thomas sente vergonha, pois o que sua narrativa expressa de ponta a ponta é a epopeia - talvez a palavra seja pouco exata para descrever a experiência que aqui se dá - da palavra que fracassa, de Orfeu que desce aos infernos para trazer sua obra, ou ao menos o que a motiva, à claridade, e fracassa miseravelmente. A vergonha suprema é acreditar que há um fim, tanto para a morte infinita de Anne, como para a infinita linguagem e oscilar de Thomas, como para o livro que o leitor e o crítico tem em mãos. Essa estrutura em 'double bind', mise en abyme falha ou "em fracasso" ${ }^{79}$, e gostaríamos de utilizar outro termo para

\footnotetext{
78 "Via-se eles saltarem desesperadamente para fora de sua fortificação, flutuar, deslizar dissimuladamente, mas quando eles criam já voar para o triunfo, ensaiando compôr com a ausência de pensamento um pensamento mais forte que devoraria leis, teoremas, sabedoria, o guardião do impossível os deteve, e eles abismaram-se no naufrágio. Queda prolongada, grave: haviam eles chegado, como sonhavam, nos confins da alma que criam percorrer? Lentamente saíram desse sonho e encontraram uma solitude tão grande que os monstros com os quais haviam os assustado quando eram homens estando próximos deles, eles os olhavam com indiferença, não viam nada e, pendurando-se sobre a cripta, permaneciam lá, em uma inércia profunda, a esperar misteriosamente que a língua que cada profeta, do fundo de sua garganta, sentiu o nascimento, saiu do mar e postou na boca as palavras impossíveis. Essa espera, vapor funesto, exalado gota a gota do topo de uma montanha, parecia que ela não poderia ter fim. Mas, quando realmente do fundo das trevas elevou-se um grito prolongado que era como que o fim de um sonho, todos reconheceram o oceano e perceberam um olhar cuja imensidade e doçura despertaria neles desejos que eles não poderiam suportar. Por um instante tornados novamente homens, viram no infinito uma imagem na qual regozijavam e, cedendo à uma última tentação, desnudaram-se voluptuosamente na água."

$79 \mathrm{Em}$ um raro texto de tom autobiográfico, intitulado Après-coup e recolhido no volume Le ressassement étérnel, Blanchot diria: "Asseguradamente, começar a escrever para alcançar
} 
descrever a centralidade dessa estrutura literária na obra ficcional de Blanchot, se repetirá em alguns outros textos, em especial em Aminadab, de 1943, e La folie du jour, de 1949. Analisá-los-emos. Deve ser notado, contudo, que a menção a um fim - o "Fin" que vem no final da versão de 1941 (em roman) da narrativa Thomas l'obscur - é ofuscado na versão-récit. A literatura, em Blanchot, acontece também nesses espaços protocolares, é a lição dessa transformação ${ }^{80}$.

imediatamente seu termo (que teria sido o encontro da última palavra), isso significa ao menos a esperança de não fazer carreira e de encontrar o mais curto caminho para terminar desde o início (seria desonesto esquecer que, no mesmo tempo ou entretempo, eu escrevia Thomas l'Obscur, que tinha talvez o mesmo propósito, mas precisamente não chegava ao fim e, pelo contrário, encontrava na busca da nadificação (a ausência) a impossibilidade de escapar ao ser (a presença) - o que, na verdade, não era mesmo uma contradição, mas a exigência de uma perpetuidade infeliz no morrer mesmo)." (BLANCHOT, 2012, p. 92)

${ }^{80} \mathrm{Em}$ um ensaio que lida com a palavra profética, Blanchot escreveu: "O irmão profeta de Acab exige que um homem o açoite e o mutile, para encenar melhor a sentença que deseja tornar compreensível para o rei. O que nos diz isso? Que é necessário tomar tudo ao pé da letra; que estamos sempre entregues ao absoluto de um sentido, da mesma maneira que estamos entregues ao absoluto da fome, do sofrimento físico e de nosso corpo de necessidade; que não há refúgio contra esse sentido que nos persegue em toda parte, nos precede, sempre ali antes de nós, sempre presente na ausência, sempre falante no silêncio. Impossibilidade, para o homem, de escapar ao ser: "Se eles cavam no sheol, minha mão irá colhê-los; se eles subirem aos céus, eu os farei descer; escondidos no Carmelo, logo os encontro; se eles pensam que podem refugiar-se no fundo do fundo dos mares, farei com que aí sejam mordidos pela Serpente." Terrível maldição da palavra que torna vã a morte e estéril o nada. Fala ininterrupta, sem vazio, sem repouso, que a palavra profética agarra e, ao agarrála, consegue por vezes interromper, para que a escutemos e, nessa escuta, despertar-nos para nós mesmos." - (BLANCHOT, 1999, p. 118) 
Capítulo IV - Aminadab e a questão da imagem 
Aminadab, segundo texto ficcional entre os que Blanchot destinou à publicação ainda na década de 1940 , de que foi dito compor a parte relativa à questão da imagem, além da parte, talvez, kafkiana do récit blanchotiano, inicia-se com uma cena aparentemente simples ${ }^{81}$ : Thomas se vê diante de uma casa, na qual não pretende entrar. Mas um gesto de uma mulher, um aceno suspenso entre o sentido e a ausência dele, talvez, acaba por fazer com que entre. É tudo: qualquer outra informação será sonegada ao leitor, como no romance anterior. Mais uma vez, convém chamar atenção para o quanto o incipit das obras de Blanchot é preciso, incisivo, como se pode notar pela passagem a seguir:

II faisait grand jour. Thomas qui jusque-là avait été seul vit avec plaisir un homme d'aspect robuste, tranquillement occupé à balayer devant sa porte. Le rideau de fer du magasin était à demi levé. Thomas se pencha un peu et aperçut à l'intérieur une femme couchée dans un lit qui tenait toute la place laissée libre par les autres meubles. Le visage de la femme, quoique tourné vers le mur, n'échappait pas à la vue: doux et fiévreux, tourmenté et pourtant déjà gagné par le repos, voilà ce qu'il était. Thomas se redressa. II n'avait qu'à continuer sa route. Mais I'homme qui balayait l'interpella :

- Entrez, dit-il tandis que son bras se tendait vers la porte et indiquait le chemin à suivre. - (BLANCHOT, 1972, p. 7) ${ }^{82}$

Esse gesto acaba por levar Thomas a entrar na casa, sem que o leitor saiba do porque de tal atitude. Note-se que, dessa vez, "il faisait grand jour", era dia pleno. A entrada, queremos crer, não é somente a do personagem, Thomas, o gêmeo, o simulacro, como sugerimos no capítulo anterior, para dentro do imóvel, mas a entrada de Thomas - e a nossa, a comunidade dos leitores possíveis - no espaço literário, no espaço da narrativa. Outra das mise en abyme de tipo muito peculiar presentes na obra de Blanchot, assim como no primeiro romance de Blanchot, (agora, talvez tenha-se notado com mais clareza, vemos que trata-se de uma obra cheia de alçapões - pièges, armadilhas, por assim dizer). Aminadab é um dos livros de Blanchot com que a crítica menos se deparou, embora tenha muito cedo

\footnotetext{
${ }^{81}$ Não obstante a intriga aparentemente simples, é importante lembrar as palavras de Levinas: “(...) para compreender a poesia de obras tão complexas quanto Aminadab ou Le Très-Haut, consideráveis, talvez enormes recursos intelectuais seriam necessários." (LEVINAS, 2003, p.63)

82 "Era dia pleno. Thomas, que até ali havia estado só, viu com prazer um homem de aspecto robusto, tranquilamente ocupado a varrer diante de sua porta. A cortina de ferro do magasin estava a meia altura. Thomas se inclinou um pouco e percebeu no interior uma mulher deitada sobre um leito que ocupava todo o espaço livre deixado pelos outros móveis. O rosto da fêmea, ainda que virado para a parede, não escapava à vista: doce e fervoroso, atormentado e no entanto já ganho pelo repouso, eis o que ele era. Thomas endireitou-se. Não tinha senão que seguir seu caminho. Mas o homem que varria o interpelou:

- Entre, disse ele enquanto seu braço tendia para a porta e indicava o caminho a seguir."
} 
merecido a atenção de um filósofo importante ${ }^{83}$, no contexto da literatura francesa. Em um dos ensaios fundamentais escritos sobre o romance, William S. Allen argumentou que o livro representa uma passagem do estilo fragmentário da primeira versão de Thomas l'obscur, passando a uma narrativa mais consistente, em que a estrutura e o espaço narrativos estão integrados de forma mais ampla, vindo assim a influenciar a escrita do primeiro (ou segundo, a considerarem-se os dois récits de Le ressassement étérnel, escritos ao longo da década de 30 e que seriam publicados somente em 1951) récit de Blanchot, a versão segunda do próprio Thomas, de 1950, assim como as narrativas que seguirão, narrativas essas que, a dar crédito a outro intérprete da obra de Blanchot, se condensam no que foi chamado de texto "pletórico" 84 . Aminadab, de todo modo, e nossa posição vai ao encontro de seus exíguos leitores, lida de forma mais direta com o problema da imagem.

É notória a importância dada por Blanchot à questão da imagem, e não só por ele, mas por grande parte dos escritores formados nos arrabaldes da vasta influência da obra de Edmund Husserl e da fenomenologia, como Jean-Paul Sartre, em seu L'imaginaire, ou Emmanuel Levinas, em La réalité et son ombre. Essa influência pode ser traçada, em especial, até a leitura que Heidegger fez do conceito de imaginação transcendental presente na Crítica do Juízo Estético de Kant. Dois aspectos dessa leitura devem ser lembrados, a princípio: o fato de que a imaginação opera de modo sintético em relação aos conceitos e intuições do entendimento; e, em segundo lugar e principalmente, a autonomia da imagem enquanto aparição, o seu ser dúbio, em que é a um só tempo apreendida e constituída pela imaginação. A imagem, portanto, não é derivada de um original, de um objeto que se apresenta antes da imagem (ainda que sob o modo de uma substituição), a imaginação abrindo o próprio horizonte transcendental da aparição. Nada, portanto, "atrás" da imagem: confrontados com a imagem, nos diz Heidegger, somos confrontados com o próprio apresentar-se do ser em sua finitude, seu "fundamento infundado", figurado como "ausência sem medida". Muito do que diz Heidegger pode ser lido simplesmente como outro modo de dissertar sobre o sentido e a linguagem, a partir de aspectos algo marginalizados da obra de Kant. As imagens, na obra de Blanchot - esperamos poder ter mostrado essa característica no capítulo anterior - são

\footnotetext{
83 SARTRE, Jean Paul. Aminadab ou du fantastique considéré comme un langage, retomado em Situations I, crítica que retomaremos no momento oportuno.

${ }^{84}$ MIRAUX, Jean-Philippe. Maurice Blanchot, quiétude et inquiétude de la littérature, p.46.
} 
construídas a partir dessa noção de distanciamento originário, as coisas e a experiência sendo constituídas por imagens, e não o contrário. O espaço narrativo a ser confeccionado tendo em vista essas noções é um que não chega a tomar lugar, a não ser no deslocamento incessante, como "imagens num espelho em que a superfície e a profundidade parecem ambas coincidir e não coincidir", no dizer de William S. Allen.

De fato, essas imagens pareceriam ser constituídas por essa estranha distância, pois a distância não é aquilo em que elas aparecem mas aquilo que é sua aparição. Se isso é a realidade das palavras, então isso tem consequências importantes não somente para a poesia, mas também de modo mais geral; pois, como Blanchot diz, o pensamento é uma função dessa realidade das palavras.

(ALLEN, 2008, p. 1105)

A complexidade dos textos de Blanchot, e de Aminadab, em especial, vem também dessa configuração ontológica do uso das imagens pelo autor, de que procuraremos dar alguns detalhes no presente capítulo, além do papel de entreposto que o livro assinala na obra de Blanchot, de passagem de um registro do roman ao récit, como bem assinalou William S. Allen ${ }^{85}$, além do próprio Blanchot, no ensaio "Le chant des sirènes", reunido em Le livre à venir.

Aminadab, de modo que os seus leitores assinalaram de certo modo distinto de Thomas l'obscur, inicia-se com o dia: "il faisait grand jour." O romance se inscreve em um registro mais "claro", diurno, de modo distinto do romance que lhe é anterior. No entanto tanto a imagem da luz como a figura do dia não tardarão a mostrarem-se responsáveis por uma escuridão mais obscura ainda do que as noites absolutas de Thomas l'obscur. A ambiguidade, dada essa possibilidade como existente, é ainda mais ambígua nesse texto. A obra é toda povoada, como veremos, de signos, acenos, imagens que não significam - não produzem o sentido - como o leitor e Thomas esperam. A narrativa inteira acontece no espaço ambíguo da casa, em que nada é o que parece e a imagem sempre aponta para um âmbito outro; trata-se de um novo modo de retratar o mencionado "deslizamento do sentido":

\footnotetext{
85 "Portanto o afastamento de Blanchot do formato do romance ao longo dos anos 40 não se dá somente por conta de suas falhas, mas sobretudo como um modo de intensificar seus efeitos, passagem de que Aminadab é uma etapa de transição, pois, mais que seus outros romances, move seu espaço para aquele do récit, e portanto inicia o passo pelo qual Thomas l'obscur será ele mesmo transformado. A experiência desse vazio novelístico é uma em que os itinerários do ler e do escrever são atraídos para esse oco através do fato de que eles envolvem seu vazio: assim como as buscas incessantes de Thomas surgem do recuo sem fim de seus encontros, assim qualquer leitura do livro, indo contra sua resistência ao sentido [meaning], retorna a uma versão de seu próprio olhar material e impessoal." (ALLEN, p. 1118)
} 
Thomas marcha carrément vers l'entrée. II regarda à droite et à gauche, puis ses regards se fixèrent sur un objet qui n'avait pas retenu son attention et qui se trouvait dans la devanture. C'était un portrait dont la valeur artistique n'était pas grande et qui avait été peint sur une toile où l'on voyait encore les restes d'un autre tableau. La figure malhabilement représentée disparaissait derrière les monuments d'une ville à demi détruite. Un arbre grêle, posé sur une pelouse verte, était la meilleure partie du tableau, mais malheureusement il achevait de brouiller le visage qui devait être celui d'un homme imberbe, aux traits communs, au sourire avantageux, autant du moins qu'on pouvait l'imaginer en prolongeant des lignes sans cesse interrompues. Thomas examina patiemment la toile. II distinguait des maisons très hautes, pourvues d'un grand nombre de petites fenêtres disposées sans art et sans symétrie, dont quelques-unes étaient éclairées. II y avait aussi dans le lointain un pont et une rivière, et peut-être, mais cela devenait tout à fait vague, un chemin qui aboutissait à un paysage montagneux. II compara en pensée le village où il venait d'arriver avec ces petites maisons édifiées les unes sur les autres, qui ne faisaient plus qu'une vaste et solennelle construction, élevée dans une région où personne ne passait. (BLANCHOT, 1972, p. 8) ${ }^{86}$

Antes de entrar na casa, Thomas nota essa estranha tela, um retrato pintado sobre os restos de uma paisagem pintada anteriormente na mesma tela. A figura, representada de modo precário, confunde-se com as ruínas de uma cidade. Diante desse retrato que se confunde com uma paisagem, a reação de Thomas é comparar a própria cidade em que ele acaba de chegar - o leitor não sabe que Thomas acaba de chegar à cidade, como de costume, assim como pouco ou nada sabe sobre os personagens de Blanchot, como foi dito - com a cidade em ruínas do quadro, com "essas pequenas casas edificadas umas sobre as outras, que não faziam mais que uma vasta e solene construção, elevada em uma região em que ninguém passava." Aqui temos, já de início, uma das mises en abyme empregadas por Blanchot, mas modificada ao ponto do estranhamento: além da semelhança imaginada por Thomas, a frase "que não faziam mais que uma vasta e solene construção" traz consigo certa ambiguidade, afinal a construção, a dar crédito a uma das possibilidades semânticas, pode ser a construção da cidade com o retrato. As imagens, aqui, parecem sugerir que não há um sentido anterior que possa ser

\footnotetext{
86 "Thomas caminhou direto para a entrada. Olhou à direita e à esquerda, então seus olhares fixaramse sobre um objeto que não havia retido sua atenção e que se encontrava na fachada. Era um retrato cujo valor artístico não era grande coisa e que tinha sido pintado sobre uma tela onde via-se ainda os restos de um outro quadro. A figura mal representada desaparecia por detrás dos monumentos de uma cidade semi destruída. Uma árvore delgada, posta sobre um gramado verde, era a melhor parte do quadro, mas infelizmente ele terminava de queimar o rosto que devia ser aquele de um homem imberbe, de traços comuns, de sorriso benéfico, ao menos como podia-se imaginá-lo prolongando as linhas interrompidas sem cessar. Thomas examinou pacientemente a tela. Ele distinguia casas muito altas, povoadas de um grande número de pequenas janelas dispostas sem arte e sem simetria, das quais algumas estavam iluminadas. Havia também na distância uma ponte e um rio, e talvez, mas isso tornava-se completamente vago, um caminho que terminava numa paisagem montanhosa. Ele comparou em pensamento a vila onde acabava de chegar com essas pequenas casas edificadas umas sobre as outras, que não faziam mais que uma vasta e solene construção, elevada numa região onde ninguém passava."
} 
descoberto por detrás das marcas na tela, mas sim a distância entrelaçada entre o retrato e a paisagem, entre o quadro e a cidade. A imagem, aqui, são as linhas interrompidas de um quadro a outro ${ }^{87}$. A profundidade e a distância que se inscrevem em cada narrativa e imagem dentro de Aminadab possuem uma singularidade e instabilidade evidentes; a linguagem, seja figurada ou figurativa, não possui no espaço narrativo descrito por Blanchot o privilégio de designar um âmbito seguro ao sentido, para além da repetição diferencial da troca de aparências. Não há um sentido acessível através de qualquer interpretação rigorosa da linguagem narrativa oferecida; há somente iterações infindas, suplementações às quais o leitor não pode se agarrar. O leitor, diante de certas imagens da literatura de Blanchot, não encontra outra oferta de sentido que a vaga morada entre o sentido e o nãosentido - algo como o neutro imaginado por Blanchot, presente nas paisagens marinhas de Thomas l'obscur, evocadas por Derrida em Parages, esses nãolugares, e agora em Aminadab, onde a configuração adquire outro sentido espacial (que diz respeito à própria constituição do sentido e ao modo como se a vê, por óbvio).

Posteriormente, Thomas se depara com um quarto em que há diversos quadros, cada um representando um quarto. O guardião, então, desejando que Thomas decida-se logo por um dos quartos, lhe diz: "vejo que se interessa por nossos quartos. Escolha então em seguida o que deseja." Em um incidente estranho, Thomas tenta examinar os quadros que mais the parecem interessantes, mas o guardião bruscamente os vira contra "o muro". Thomas protesta, quer virar um dos quadros de volta para si, mas o guardião o impede, gritando: "esse está alugado." Thomas, então, diz que "celui-là est loué." Não lhe é possível discernir, nesse momento, se o que estava alugado era o quadro ou o próprio quarto. A representação e o original se confundem na cena blanchotiana, na confusão da dêixis ${ }^{88}$. Thomas então deixa o cômodo.

\footnotetext{
${ }^{87}$ Comentando a mesma passagem inicial do livro, William S. Allen interpretou-a da seguinte forma: "Enquanto ambas imagens dizem respeito ao espaço narrativo que ele está prestes a adentrar, nenhuma é mais significativa que a outra, ambas de fato se sobrepõem como as linhas de uma imagem interferem uma na outra, mas na distância entre as duas tudo é vago. Isso poderia parecer sugerir não que há um significado subjacente que poderia, sendo descoberto, obter sentido dessas imagens, mas sobretudo que nada há atrás delas e que enquanto tais essas são imagens desse mesmo nada. Então é em sua insubstancialidade mesma, em sua insignificância que essas imagens levam ao que as subjaz, o que não quer dizer que sejam todas igualmente arbitrárias, pois somente essas imagens que atendem a essa distância que tornam-se imagens dela."- MLN, p. 1109.

${ }_{88}$ A respeito do uso dos pronomes, em Blanchot, como modo de gerar instabilidade na referencialidades dos textos, Jérémie Majorel demonstrou que em alguns momentos de Aminadab
} 
Mais de uma vez, em sua jornada pela casa, Thomas se depara com quadros. Esses quadros representam quartos, quartos que podem ser alugados ou não, aparentemente coincidindo os quartos pintados com os quartos da maison em que Thomas transita. Mas eis que, de repente, se encontra na sala que contém, em meio aos dejetos da arte in natura, um quadro que aparentemente representa a própria sala, mas, à diferença dos quadros anteriores, representa à perfeição o que Thomas tem diante dos olhos. Encontramos, então, o seguinte trecho do romance:

\begin{abstract}
La toile s'étendait maintenant devant lui et il voyait qu'un tableau y avait été esquissé, tableau représentant comme tous les autres une chambre meublée, justement la chambre où il se tenait en ce moment. II put constater avec quel souci d'exactitude travaillait le peintre. Tous les détails étaient reproduits. Ce n'était encore qu'une esquisse et cependant les moindres objets, à l'exception il est vrai du divan, étaient mis à leur place et l'on pouvait se demander ce qu'une étude plus complète ajouterait à la fidélité de l'imitation: c'était à croire que l'on ne distinguerait plus la chambre du tableau. Seule, la couleur manquait. Thomas remarqua avec un léger malaise que le tabouret sur lequel il était assis figurait sur la toile. Peut-être avait-il agi avec irréflexion. - (BLANCHOT, 1972, p. 20) ${ }^{89}$
\end{abstract}

Temos aqui o início de mais um dos esquemas em que Blanchot reelabora, reestratifica ou subverte, trazendo-Ihe um ponto de fuga, a mise en abyme, ou, de outro modo, a passagem de um nível metalinguístico a um nível extralinguístico, de uma imagem à coisa, da linguagem ao ser, a dar-se conta do aspecto ontológico desse subterfúgio; quando Thomas percebe, com um suave mal-estar, que mesmo o banco em que se encontra sentado está figurado no quadro, com exceção do próprio Thomas, a voz narrativa nos diz: "talvez ele houvesse agido com irreflexão", irreflexão, talvez, no sentido de uma tentativa fútil de extinguir o deslocamento da estrutura do sentido, de tentar dar conclusão à sequência de reflexos de dois espelhos postos frente à frente. Após isso, Thomas se dirige ao guardião novamente - a imagem obviamente remete ao guardião de Kafka - e soa irrisório que Blanchot tenha alegado não haver lido Kafka até então (na época da redação de Aminadab) -

Blanchot investe em procedimentos que buscam neutralizar a dêixis, o uso indicativo dos pronomes, o que torna a sintaxe de sua frase muitas vezes "indecidível" (MAJOREL, 2010, p. 99-100)

89 "A tela se estendia agora diante dele e ele via que um quadro aí havia sido esboçado, quadro que como todos os outros representava um quarto mobiliado, justamente o quadro onde ele se encontrava nesse momento. Ele pode constatar com que cuidado de exatidão trabalhava o pintor. Todos os detalhes estavam reproduzidos. Isso não era ainda senão um esboço e no entanto os menores objetos, à exceção, é verdade, do divan, estavam postos em seu lugar e podia-se questionar o que um estudo mais completo adicionaria à fidelidade da imitação: era possível crer que não se distinguiria mais o quarto do quadro. Somente a cor faltava. Thomas assinalou com um ligeiro mal estar que o tamborete sobre o qual estava sentado figurava sobre a tela. Talvez ele tivesse agido com irreflexão." 
com a sensação nítida de o guardião haver passado por uma transformação profunda. Então, curiosamente, uma sensação de tranquilidade invade Thomas: ele imagina já haver estado lá. Imagina que o episódio que vive já aconteceu, que é apenas a repetição oca de um outro instante, apenas isso: "tudo isso já não tinha acontecido? Já uma vez cruzar as mãos, abrir e fechar os olhos, ser não iluminado mas mergulhado nas trevas pela luz, ele havia assistido a esta cena e ela tinha tido um sentido que ela jamais teria novamente." Trecho que, certamente, faz pensar em Thomas l'obscur, e que esse segundo livro - anterior à segunda versão do primeiro, e ainda sob a alcunha genérica de roman, embora já despido de capítulos - é somente a repetição do outro livro, repetição antes da própria repetição que se daria quando Blanchot decide publicar uma segunda versão do primeiro livro em 1950, sob a alcunha, pela primeira (?) vez, de récit. A cena ${ }^{90}$, em Blanchot, a cena literária, se podemos tomar a liberdade, sempre diz esse momento anterior que se repete, anterior não no sentido de originário em uma hierarquia ontológica hipotética ou mimética, mas anterior no sentido de evocar a repetição, o esvaziamento e a disseminação do sentido a um só tempo. Na cena em questão encontramos Thomas sendo retratado por um pintor que gostaria de limitar-se ao retrato, à mimese:

\begin{abstract}
D'ailleurs, le peintre ne négligeait pas toujours son tableau. Pendant de brefs instants, il y travaillait avec une grande ardeur sans, il est vrai, se préoccuper davantage de son modèle. Thomas avait l'impression de ne pas être là ou, par le fait qu'il avait été mis à cette place, de faire déjà partie du tableau, de sorte que la reproduction de ses traits n'avait plus grande importance. De temps en temps, le peintre tirait de sa poche une miniature qu'il regardait avec soin puis qu'il copiait sans vergogne. La copie semblait son art favori. - (BLANCHOT, 1972, p. 22-23) ${ }^{91}$
\end{abstract}

\footnotetext{
90 "Une scène primitive", fragmento do livro L'Écriture du désastre, já dizia: " (Uma cena primitiva?) Vocês que vivem mais tarde, próximos de um coração que não bate mais, suponham, suponham-no: a criança - ela teria sete anos, oito anos talvez? - de pé, afastando a cortina e, através da vidraça, olhando. O que ela vê: o jardim, as árvores de inverno, o muro de uma casa: enquanto ela vê, sem dúvida à luz de uma criança, seu espaço de jogo, ela se cansa e lentamente olha para o alto em direção ao céu ordinário, com as nuvens, a luz cinza, o dia opaco e sem distância.(...) O que se passa em seguida: o céu, o mesmo céu, repentinamente aberto, negro absolutamente e vazio absolutamente, revelando (como que pela vidraça quebrada) uma tal ausência que tudo nela desde sempre e para sempre se perdeu, a ponto que nela se afirme e se dissipe o saber vertiginoso de que nada é aquilo que há, e de saída nada para-além". O inesperado dessa cena (seu traço interminável) é o sentimento de felicidade que imediatamente submerge a criança, a alegria devastadora da qual ela não poderá testemunhar senão pelas lágrimas, um escoamento sem fim de lágrimas. Crê-se numa tristeza de criança, procura-se consolá-la. A criança não diz nada. Ela viverá doravante no segredo. Não chorará mais." (BLANCHOT, 1980, p. 117. O itálico é do autor.)

91 "Por outro lado, o pintor não negligenciava sempre seu quadro. Durante uns breves instantes, ele nele trabalhava com grande ardor, sem, é verdade, preocupar-se demais com seu modelo. Thomas tinha a impressão de não estar ali ou, pelo fato de que tinha sido situado naquele lugar, de fazer já parte do quadro, de sorte que a reprodução de seus traços não tinha mais grande importância. De tempos em tempos, o pintor tirava de seu bolso uma miniatura que ele perscrutava com cuidado e que copiava sem vergonha. A cópia parecia sua arte favorita."
} 
Esse pintor, então, começa a pintar o retrato de Thomas e o divã, que eram as únicas coisas ainda não duplicadas no quadro e presentes no quarto. A cópia é tão minuciosa, no que diz respeito às vestes, que incomoda Thomas, causando-lhe uma sensação "bizarra e desagradável". A ideia de uma imagem retratar à perfeição qualquer coisa é impossível para Thomas. O rosto é totalmente dessemelhante: um rosto triste, envelhecido, que parecia ter perdido, com o tempo, "toda a significação", exceto no que dizia respeito ao olhar. "(...) O pintor havia Ihe dado uma expressão estranha, não vivente, pois parecia pelo contrário condenar a existência, mas ligada à lembrança da vida por uma reminiscência perdida no meio dos escombros e ruínas." O Thomas de Aminadab também é, ou ao menos é retratado assim nessa mise en abyme, vindo da ruína que é a própria arte, dos escombros do sentido que constituem o espaço literário. A pintura do pintor tem um caráter fascinante, como tudo na obra ficcional de Blanchot, "do qual não se podia soltar". Então tudo como que se encerra, e o guardião-pintor joga panos e coberturas e véus por sobre os móveis retratados no quadro. Tudo cessa, tudo se encobre de escuridão, tanto as coisas retratadas quanto a luz que ilumina a sala, evidenciando, talvez, tratar-se do mesmo espaço. Thomas se retira.

\footnotetext{
Celle-ci perdait l'aspect chaotique que la lumière rendait si agréable. L'obscurité l'envahit presque complètement. Le gardien étendit sur le divan une housse de couleur mate et au moyen d'une triangle il fit descendre sur le chevalet un grand voile qui le recouvrit. Les autres meubles disparurent sous des couvertures. Le dernier objet qui restait à dissimuler était une toile pendue au mur, puis ce fut terminé. Thomas vit qu'il fallait partir, la chambre était déjà vide. - (BLANCHOT, 1972, p. 24) ${ }^{92}$
}

Thomas então é levado por outra pessoa a outro cômodo, a outra antessala do sentido, mais um cômodo em que a visão é limitada, em que a luz não penetra por completo. Passa por um corredor sombrio, extremamente escuro, em que não podia ver muito, como os corredores e passagens e portas todas que mencionamos no segundo capítulo, quando tratávamos da literatura em geral na obra de Blanchot,

\footnotetext{
92 "Esta perdia o aspecto caótico que a luz tornava tão agradável. A obscuridade a invadia quase completamente. O guardião estendeu sobre o divan uma capa de cor opaca e no meio de um triângulo fez descer sobre o cavalete um grande véu que o recobriu. Os outros móveis desapareceram sob as coberturas. O último objeto que restava à dissimular era uma tela pendurada na parede, então isso foi terminado. Thomas viu que era necessário partir, o quarto já estava vazio."
} 
esses vestíbulos escuros e de difícil acesso dos quais sua obra é repleta, presença vital em sua obra que Foucault foi talvez o primeiro a assinalar ${ }^{93}$.

Em um momento em que já há tempo que Thomas move-se pelos cômodos da casa, depois, enfim, de muitas especulações em que Thomas busca a lei que rege a casa e a lei que rege sua própria escritura, e a de seus habitantes, Dom, o companheiro de Thomas, que o acompanha em silêncio ao longo de quase toda a extensão do livro, personificação da circunspecção, diz a Thomas que até então ele havia tomado o caminho errado. Estamos agora no fim do relato. Thomas deveria ter buscado os níveis subterrâneos, e não os andares de cima, como havia feito. O personagem, então, muito cansado, e à maneira do primeiro Thomas, é consumido pela noite que invade a casa. Como os demais livros de Blanchot, Aminadab resiste a sumários ou resumos, como se pode notar, pela estranheza que traz a concatenação dos episódios relatados. Thomas, afinal, chega onde queria ter chegado desde o princípio da narrativa: nos andares de cima da casa, no "cômodo final", que deveria encerrar a passagem inexorável de cômodo a cômodo.

Essa passagem de cômodo a cômodo foi assimilada, por alguns intérpretes de Aminadab, como a passagem inexorável de um sentido a outro, de uma inscrição a outra, de um registro semântico a outro, o espaçamento da infinitude característico do espaço literário, personificado, entre outros poetas da predileção de Blanchot, pelo Un coup de dés de Stéphane Mallarmé. Note-se que é possível verificar mesmo uma analogia entre a passagem figurativa de uma antesala do sentido à outra com o movimento da frase de Blanchot, como bem assinalou Alain Milon em um texto recente, produzido no contexto de um colóquio sobre a noção de récit na obra ficcional de Blanchot ${ }^{94}$ : a frase em Blanchot busca emular esse movimento de passagem, de infinitude, em que um vocábulo ocupava espaço somente provisório, em que o que interessa é a próxima palavra, a impossibilidade, enfim, de um dernier mot, como Blanchot colocou em seus ensaios sobre Kafka, reunidos posteriormente em De Kafka à Kafka.

Nesse momento, Lucia alega não ser a mulher que primeiramente acenou, convidando Thomas a entrar na casa. E a revelação de Dom acaba por também mostrar-se opaca: pois mesmo se Thomas houvesse seguido aos porões, acabaria

\footnotetext{
${ }^{93}$ No ensaio "La pensée du dehors", recolhido posteriormente no volume dos Ditos e Escritos dedicado à literatura (em português).

${ }^{94}$ MILON, Alain (org.). Maurice Blanchot, entre le roman et le récit, p. 22.
} 
retornando à superfície. Mesmo o guardião, Aminadab, parece ser fruto tão somente da imaginação dos inquilinos responsáveis pela confusão interpretativa em que vive Thomas. A comunicação de Thomas com os inquilinos termina por fracassar. A lei termina por prevalecer sobre Thomas, consumindo-o junto à escuridão. Thomas ainda possui uma última fala antes do final (?) do texto: "Quem é você?", uma tentativa última de claridade que é engolida pela noite junto com ele. Aminadab, o título, opera de modo algo distinto dos demais títulos microliterários de Blanchot. $\mathrm{O}$ nome pode referir-se a duas referências: uma no "cântico espiritual" de São João da Cruz, em que é associado ao conflito, ao tumulto (no cântico, Aminadab é um representante das forças do demônio, uma presença negativa que pode irromper no diálogo entre o Logos divino e a alma do fiel); e uma na genealogia do Cristo, no evangelho de Mateus. Gary D. Mole considera que o desvio que Dom revela que Thomas deveria ter tomado, em direção a Aminadab, o guardião do subterrâneo e supostamente dos segredos da lei da casa, seria apenas mais um erro; Aminadab falha, portanto, em seu valor genealógico, de origem. Nenhum dos inquilinos, nem mesmo Dom, o simulacro de Thomas, foram capazes de compreender ou negociar as leis da casa, apropriar-se da casa, enfim. A relação entre a lei e a escritura, entre a lei e o espaço literário, entre a lei do sentido e o sentido da lei é, portanto, em Aminadab uma vez mais, a da interminabilidade da interpretação, ou, nos termos de Ann Smock,

A lei que governa a casa em Aminadab é incansavelmente, de fato fastidiosamente esclarecida, como se não houvesse fim para as sentenças que a concernem, pois mesmo as mais contraditórias não refutam a si mesmas mas se expandem, e muito, para acomodar umas às outras (SMOCK, 1976, p. 99)

O espaço literário - manifestado, se quisermos, no espaço da própria casa, ou o espaço que se espaça junto à lei da casa - se concretiza na infinidade de interpretações que se acomodam, se empilham nos episódios descritos no livro. Como em qualquer outro de seus livros, o que sempre acontece com os personagens de Blanchot, quando buscam encarar diretamente a lei do que lhes permite vivenciar a inteligibilidade do mundo e das coisas? - sempre que esbarram em figuras como a da lei, e esse episódio se repete consideráveis vezes, o que os personagens de Blanchot encontram é uma sequência ambígua de alçapões, desvios, distanciamentos. Esse episódio se repete em Aminadab. O próprio lidar 
com a lei é já uma mise en abyme, um lidar com a lei que rege o signo, o livro, a linguagem. ${ }^{95}$

E, quando Thomas tenta rubricar seu nome na declaração estendida a ele por Lucie, acaba também ele por ser diluído na noite. O livro, mais uma vez, assim como Thomas l'obscur, de dois anos antes, falha em finalizar. Thomas é levado a concluir, por força dos acontecimentos, que não conseguiu nada, que o gesto - que ele não soubera definir se era um convite ou um simples aceno - feito pela mulher do começo do romance talvez não significasse nada, assim como todas as outras imagens apresentadas no livro (e como talvez a maior parte das imagens e figuras da ficcção blanchotiana). Cada vez que Thomas tentou constituir uma narrativa, um récit, uma frase que fosse sobre as leis que regem o funcionamento da casalabirinto, ou uma definição de qual era sua intenção, seu eu, em relação à casa, quais eram seus propósitos ali, ele se depara com a negatividade dos inquilinos ou das imagens. Não há pessoas nos andares de cima, dizem os inquilinos, não haveria como o aceno ter sido sequer feito. Nada acontece na casa, e portanto não pode haver, segundo esses, um propósito ou motivo para a estadia de Thomas ali. Thomas, questionado em vários momentos do relato, assim como o leitor que lê Aminadab, ou ao menos como o leitor desejado por Blanchot, recusa todas essas narrativas e relatos, imagina-os insuficientes para dar conta do que testemunham de fato, ou simplesmente infiéis a esse testemunho, testemunhos do perjúrio, postura que inclusive os habitantes da casa consideram indigna. Mas não se pode dizer, como de resto da maior parte da ficção de Blanchot, simplesmente, que Aminadab não possui sentido algum, que a jornada de Thomas não tem significado algum; Thomas jamais se deixa prender a uma só interpretação, a uma interpretação final dos acontecimentos, das imagens e das leis da casa. Nem o sentido nem a ausência de sentido são a chave para a interpretação dessa obra, que é uma mise en abyme por si só, num sentido global.

Thomas nunca simplesmente aceita as explicações ofertadas pelos habitantes da casa, como mencionamos. Um exemplo claro é a passagem seguinte, presente mais adiante no texto, quando Thomas, após tentar até à fadiga, finalmente consegue se aproximar de um jogo que está sendo jogado por outros inquilinos:

${ }^{95} \mathrm{O}$ presente trabalho, se pode delimitar com clareza sua lei - sua tese - seria essa: a de que a microliteratura de Blanchot inclui em seus experimentos um experimento essencial com a mise en abyme, com um retrabalho do choque da obra sobre a própria obra, o que leva Blanchot a prestar mais atenção e privilegiar certas estruturas e subterfúgios. 
Thomas opina de la tête, comme pour dire : Oui, voilà justement la question qui m'intéresse, mais il ne pouvait qu'être méfiant.

- Ceux qui ont gagné, ajouta le voisin, sont déjà presque tous partis. Les autres seront probablement désignés à la dernière minute, mais l'employé ne désigne que les personnes dont il connaît les visages. Vous n'avez donc aucune chance.

Thomas écoutait d'une oreille distraite. Ce n'était pas encore celui-là qui lui dirait la vérité.

- C'est donc, dit-il, l'employé qui désigne les gagnants?

- Non, dit l'homme, les noms des gagnants sont inscrits sur les documents.

- Alors, dit Thomas, le choix n'appartient pas à l'employé.

- Naturellement, dit le voisin; l'employé se contente d'identifier ceux qui gagnent; il obéit à ce qui est écrit; mais pour le reste il est libre.

- Voilà qui explique tout, dit Thomas pour mettre fin à l'entretien.

En réalité, il le savait bien, rien n'était expliqué et même si les explications de son voisin avaient été meilleures, il n'eût pu y attacher aucun crédit, tant le désir de le fourvoyer apparaissait dans tout cela. L'homme cependant crut l'avoir sérieusement ébranlé. - (BLANCHOT, 1972, p. 66) ${ }^{96}$

O exemplo acima ilustra bem as relações que Thomas, que se mostra ao longo da narrativa uma espécie de hermeneuta cuidadoso dos sentidos e palavras que lhe apresentam, mantém com os outros inquilinos: relações carregadas de ceticismo, de desconfiança, em que somente uma certeza se mantém, a certeza de que o interlocutor está faltando com a verdade. Essa é a natureza da relação que na maior das vezes ele mantém com seus principais interlocutores, como Barbe, Dom, e outros que permanecem anônimos. O sentido nunca está presente de todo em nenhum dos diálogos estabelecidos: está sempre aquém ou além da conversa. $E$, no entanto, embora perceba e desconfie de todos inquilinos, como demonstrado pelas passagens grifadas acima, Thomas nunca desiste de buscar esse sentido, não desiste, de todo, do ímpeto de encontrar a verdade subjacente, uma lei inexorável que dite os rumos da casa. Uma casa - oikos - deve, naturalmente, possuir uma lei - nomia - uma economia, uma inscrição responsável por distribuir os valores semânticos. A dificuldade de Thomas não exclui sua necessidade de compreensão,

\footnotetext{
96 "Thomas opinou com a cabeça, como que para dizer: Sim, eis justamente a questão que me interessa, mas ele não podia estar senão desconfiado.

- Aqueles que ganharam, completou o vizinho, já partiram quase todos. Os outros serão provavelmente designados no último minuto, mas o empregado não designa senão as pessoas cujos rostos conhece. Você não tem chance alguma.

Thomas escutava com ouvidos distraídos. Esse não era ainda aquele que lhe diria a verdade.

- É então, diz ele, o empregado que designa os vencedores?

- Não, disse o homem, os nomes dos ganhadores são inscritos sobre os documentos.

- Então, disse Thomas, a escolha não pertence ao empregado.

- Naturalmente, disse o vizinho; o empregado se contenta em identificar aqueles que ganham; ele obedece ao que está escrito; mas para o resto ele é livre.

- Eis o que explica tudo, disse Thomas para dar fim à conversa. Na realidade, ele o sabia bem, nada estava explicado e mesmo se as explicações de seu vizinho tinham sido melhores, ele não pode darIhes crédito algum, tanto o desejo de induzir ao erro aparecia naquilo tudo. O homem todavia creu havê-lo abalado seriamente." (os grifos são nossos)
} 
sempre acompanhada de certa disjunção, de um hiato entre as palavras e seus sentidos (por exemplo: “(...) a palavra trabalho não chegava senão lentamente ao espírito de Thomas. Antes que ele houvesse Ihe compreendido o sentido, outras se aproximaram, e a maneira como cada um repetia a frase ou uma frase análoga, em voz alta ou em voz baixa, o impediu de se deter sobre a significação dessa palavra." O fato dos habitantes também serem dados ao comentário infinito também acaba por influenciar as atitudes de Thomas em relação a seu discurso confuso. O nãoentendimento, a impossibilidade de comunicação entre Thomas e os habitantes da casa acabam por levá-lo ao ceticismo, e à crença, talvez, na infinidade da interpretação. Quanto a isso é importante lembrar uma passagem da página 84, em que Thomas é acusado por um interlocutor de "julgar demasiado severamente" o que lhe dizem os locatários, passagem que explicita algo da natureza desses locatários:

\begin{abstract}
Par conséquent, continua-t-il, vous êtes ignorant des choses d'ici et vous avez tendance à juger sévèrement ce que vous voyez. Tous les débutants sont ainsi. Comment pourraient ils mettre les pieds dans cette maison obscure et mal tenue sans avoir une fâcheuse impression? II n'y a pour eux que des motifs de se plaindre, et quels motifs! Connaissent-ils seulement la chambre où ils habitent? A peine s'y sont-ils établis qu'on les force à déménager. Nous avons coutume de dire que les locataires sont d'éternels vagabonds qui ignorent même leur chemin. C'est un peu exagéré, mais c'est vrai au fond. A part quelques privilégiés dont on respecte les caprices, personne ne peut jurer qu'il couchera deux fois dans le même lit, et ce n'est qu'un va-et-vient de gens, parfois réveillés en plein sommeil, qui à demi habillés portent dans les couloirs leur linge en désordre. - (BLANCHOT, 1972, p. 84) ${ }^{97}$
\end{abstract}

Um pouco adiante, e nesse momento nos aproximamos da metade do romance - ou récit, como classifica Christophe Bident na única e muito útil biografia escrita sobre Blanchot ${ }^{98}$ - há um episódio que chamou a atenção de mais de um intérprete, como foi o caso de William S. Allen, tanto pelo que contém de insólito, como também pelo fato de ser outra mise en abyme do tipo que buscamos detectar

\footnotetext{
97 "Por conseguinte, ele continuou, você é ignorante das coisas daqui e você tem tendência aj ulgar severamente o que você vê. Todos os novatos são assim. Como poderiam eles colocar os pés nesta casa obscura e mal ajambrada sem ter uma impressão desagradável? Não há para eles senão motivos para se queixar, e que motivos! Conhecem eles somente o quarto em que habitam? Mal estão aí estabelecidos e já se os força a mudarem-se. Nós temos o costume de dizerque os locatários são eternos vagabundos que ignoram mesmo seu caminho. É um pouco exagerado, mas no fundo verdadeiro. À parte de alguns privilégios de que se respeita os caprichos, ninguém pode jurar que dormirá duas vezes no mesmo leito, e isso não é senão um vai e vem de pessoas, por vezes despertadas em pleno sono, que semi trajados levam aos corredores sua roupa suja em desordem."
}

${ }_{98}$ BIDENT, Christophe. Maurice Blanchot, partenaire invisible, p. 207. 
no presente trabalho. Através de uma janela aberta, Thomas vê um homem balançando um cântaro no ar frio, como se procurando refrescar seu conteúdo, e do qual percebe sair uma luz. Guardemos esse momento; será importante em breve. Após isso, e após Thomas mencionar que ainda não havia sofrido as dificuldades e reveses da casa, um dos dois interlocutores de Thomas, que se encontram sentados com ele à mesa, falam sobre a trajetória recorrente de quem entra na casa: a que situações as pessoas são submetidas, como a situação de Thomas, que ainda não dispõe de um quarto, embora já tenha vagado pela casa durante incerto tempo; "No começo toma-se partido, uma certa liberdade tem seu charme, crê-se sempre que poder-se-á retornar ao quarto que deixamos. Mas essas ilusões rapidamente esvanecem. Quando se provou a que tédios se expõe se não se conhece de antemão seu quarto, quando se vê empurrado de porta em porta, quando mesmo os quartos vazios vos são fechados, não se goza mais da incerteza dos conhecimentos e a liberdade parece uma desgraça a que se busca em vão comprar-se." É dito também, em outro momento do texto, que os locatários vivem em uma "noite perpétua".

A "incerteza dos começos", aqui, faz pensar novamente no começo do livro, quando Thomas entra onde não intencionava entrar devido a um aceno que não sabia dizer mesmo se se tratava de um convite. Essa noção de um começo impossível da narrativa pode ser lida ao menos de dois modos, e ambos são cruciais na ficção de Blanchot, e em especial em Aminadab: no sentido de que todo começo é incerto, isto é, de que pode não ser o começo referido o começo de fato, como é o caso da estrutura narrativa do texto La folie du jour, que analisaremos no próximo capítulo; como no sentido ontológico de que qualquer início é arbitrário e impossível, de que o começo, ainda que o começo de direito, é ele mesmo incerto ou impossível: não há modo de delimitar um início que não seja esvaziado pela incerteza estrutural que a própria linguagem carrega consigo. Começo incerto, sobretudo, do livro que se tem em mãos: "Il faisait grand jour". Como veremos em capítulo posterior, a etimologia da palavra jour funciona, em Blanchot, remete à imagem da própria proliferação do sentido: jornada, luz, abertura.

Mas retornemos ao episódio em questão. Algumas páginas a seguir, o interlocutor de Thomas segue Ihe dando informações quanto às características da relação dos habitantes da casa com o "pessoal", com os empregados: 
Comment pourrais-je d'ailleurs vous en parler ? L'essentiel est que justement il n'y a rien à en dire, il ne se passe rien, il n'y a rien. Je vous ai averti que le personnel était la plupart du temps invisible. Sottise qu'une telle parole, tentation orgueilleuse à laquelle j'ai cédé et dont je rougis. Invisible le per sonnel? La plupart du temps invisible? Mais jamais nous ne le voyons, jamais nous ne l'apercevons, même de loin; nous ne savons même pas ce que peut signifier le mot voir lorsqu'il s'agit de lui, ni s' il y a un mot pour exprimer son absence, ni si la pensée de cette absence n'est pas une suprême et désolante ressource pour nous faire espérer sa venue. (BLANCHOT, 1972, p. 90) ${ }^{99}$

\begin{abstract}
Após uma longa história, em que é contada a história, em que é provido o relato - o récit - do enfrentamento entre os inquilinos e a lei da casa, e em que determinado momento, enlouquecidos, atravessaram a "linha ideal", e terminaram, enfim, por tornar-se invisíveis, ou pior, tornar-se espectros que nos limiares da casa acenam para atrair mais locatários para dentro da casa, Thomas vivencia a cena seguinte, uma pletora de interpretações possíveis, assim como toda a extensão do texto ficcional de Blanchot: a multiplicação do gesto do primeiro homem que balançava o cântaro. Vejamos a cena:
\end{abstract}

La salle était à demi plongée dans l'obscurité. Mais, fait curieux, il y avait maintenant sur l'estrade plusieurs personnes qui avaient à la main une cruche d'où s'échappaient quelques rayons. À la faveur de cette douce lumière, Thomas atteignit la table où se tenaient les deux employés: de nombreux invités buvaient avec eux et ils le dévisagèrent avec cette curiosité insatiable dont ils avaient déjà donné tant de preuves.

- Partons, dit Thomas aux deux hommes.

- Voici notre locataire, répondit le plus âgé des deux, mais ni l'un ni l'autre ne se levèrent pour le suivre.

- Je m'en vais donc, dit Thomas.

II dut bousculer les spectateurs qui se pressaient autour de lui et lui barraient le chemin: l'un d'eux lui avait saisi le bras et voulait l'accompagner. "Triste société", pensa-t-il. Les têtes qu'il apercevait semblaient rongées par la maladie, et la finesse des traits apparaissait comme un signe de débilité. Les deux employés, se voyant soudain abandonnés à leur table, préférèrent se joindre à la petite troupe groupée autour de Thomas et c'est une suite triomphale qui se dirigea vers la porte au milieu des rires, des cris et même des chants. Une circonstance changea cette gaieté en désordre. Les gardiens de l'estrade élevèrent leur cruche et la lumière baigna toute la salle. Les torches qui étaient enfermées dans les pots de grès jetèrent une si vive clarté que chacun se cacha la figure pour n'en pas subir les atteintes, et quelques-uns, déjà à demi ivres, tombèrent à terre en croyant qu'on les frappait, ce qui les fit crier de toutes leurs forces sans qu'il y eût pour cela une cause sérieuse. Thomas ne s'arrêta qu'un instant. II avait hâte de quitter la salle. Quelle pénible réunion! Dans son désir de rester libre, il se demanda s'il n'abandonnerait pas les deux employés. Mais ceux-ci, le voyant indécis et prenant

\footnotetext{
99 "Como poderia eu, por outro lado, Ihes falar disso? O essencial é que justamente não há nada a dizer sobre isso, nada se passa, não há nada. Eu vos adverti que o pessoal era a maior parte do tempo invisível. Besteira que uma tal fala, tentação orgulhosa à qual cedi e da qual me envergonho. Invisível o pessoal? A maior parte do tempo invisível? Mas nunca nós os vemos, nunca os percebemos, mesmo de longe; nós não sabemos mesmo o que pode significar a palavra ver quando deles se trata, nem se há uma palavra para explicar sua ausência, nem se o pensamento dessa ausência não é um supremo e desolador recurso para nos fazer esperar sua vinda."
} 
son hésitation pour de la tristesse, se pendirent à son bras comme pour faire équilibre à Dom; et ils marchèrent tous les quatre à grands pas vers la porte. Un gardien les attendait. C'était l'homme qui l'avait appelé sur le balcon. II avait brisé la cruche dont les morceaux étaient éparpillés sur le sol et la flamme brûlait tranquillement.

- Vous devez vous séparer, dit-il de sa voix autoritaire.

- Est-ce indispensable? demanda Thomas.

- Je dois reconduire ces deux-là, dit le gardien sans répondre directement.

- Je vous tiendrai donc compagnie, dit Thomas, et ils partirent tous ensemble. (BLANCHOT, 1972, p. 133-134) ${ }^{100}$

William S. Allen chamou a atenção para a presença, nessa passagem, de uma parábola muito curiosa. No momento mesmo em que os habitantes da casa buscam enfrentar a lei, isto é, visar a lei diretamente, torná-la presente em seus anseios e operações, por assim dizer, assim como o leitor busca tornar presente o significado do texto, ou ao menos a lei desse significado, a lei que rege os sentidos do texto que tem em mãos, Blanchot situa, no começo e no fim da cena, a figura do homem que balança o cântaro que aparentemente - e não mais que aparentemente - emite luz. No fim da cena, são vários os homens a balançar seus cântaros que emitem luz, ao ponto de criar sensação de confusão nos presentes. Por fim, aparece o primeiro homem - o guardião - com seu cântaro quebrado, somente a chama

\footnotetext{
100 "A sala estava semi mergulhada na escuridão. Mas, fato curioso, havia agora sobre a plataforma diversas pessoas que tinham na mão um cântaro de onde escapavam alguns raios de luz. Sob o favor desta doce luz, Thomas chegou à mesa onde estavam dois empregados: numerosos convidados bebiam com eles e olhavam fixamente com esta curiosidade insaciável de que já tinham dado tantas provas.

- Partamos, disse Thomas aos dois homens.

- Eis nosso locatário, respondeu o mais velho entre eles, mas nem um nem outro se levantaram para seguí-lo.

- Então me vou, disse Thomas.

Ele teve que empurrar os espectadores que se amontoavam ao seu redor e the barravam o caminho: um deles lhe tomou o braço e queria acompanhá-lo. 'Triste sociedade', pensou. As cabeças que ele percebia pareciam roídas pela doença, e a fineza dos tratos aparecia como um signo de debilidade. Os dois empregados, se vendo subitamente abandonados em sua mesa, preferiram juntar-se à pequena tropa agrupada ao redor de Thomas e é uma comitiva triunfal que se dirigiu à porta em meio a risos, gritos e mesmo cantos. Uma circunstância transformou esta alegria em desordem. Os guardiões da plaftaforma elevaram seus cântaros e a luz banhou toda a sala. As tochas que estavam enclausuradas em vasos de arenito jogaram uma claridade tão viva que cada um escondeu o rosto para não sofrer os golpes, e alguns, já meio ébrios, tombaram na terra crendo que alguém os golpeava, o que os fez gritar com todas suas forças sem que houvesse para isso uma causa séria. Thomas não se deteve senão por um instante. Ele tinha pressa de abandonar a sala. Que reunião penosa! Em seu desejo de permanecer livre, ele se questionou-se se não abandonaria os dois empregados. Mas esses, vendo-o indeciso e tomando sua hesitação por tristeza, se penduraram em seu braço como que para dar equilíbrio a Dom; e então caminharam os quatro a grandes passos em direção À porta. Um guardião os esperava. Era o homem que o havia chamado do balcão. Ele havia quebrado seu cântaro, cujos pedaços estavam espalhados pelo solo e a flama queimava tranquilamente.

- Vocês devem se separar, disse ele com sua voz autoritária.

- Isso é indispensável? Perguntou Thomas.

- Eu vejo reconduzir esses dois, dissse o guardião sem responder diretamente.

- Eu vos farei então companhia, disse Thomas, e eles partiram todos juntos."
} 
restante de uma tocha permanece. Allen nos lembra da semelhança desse episódio com um provérbio da língua francesa, que diz "tant va la cruche à l'eau qu'elle se brise". Como de resto por toda a parte na ficção de Blanchot, em um movimento que alguns já disseram começar especificamente em Aminadab, esse ditado diz respeito à fixação de Blanchot pela leitura que não encontra nenhuma pausa, nenhuma parada, nenhuma garantia, dado que mesmo o que aparentemente resiste - 0 cântaro - pode ser minado pelas coisas aparentemente mínimas, suaves - a água $^{101}$. O sentido pode implodir, aquoso, o cântaro do próprio sentido. Assim como o tom geral da cena, em que o interlocutor de Thomas é ambíguo a respeito da importância ou não da história que acaba de contar, dizendo mesmo que são casos passíveis de interpretações múltiplas, Aminadab - como a escritura de Blanchot em sentido amplo - expressa enquanto narrativa o acontecimento desse distanciamento entre sentido e referência. A cena funciona, assim como tantas outras em Blanchot, como uma mise en abyme diferenciada, uma mise en abyme sem clausura, que instala, aliás, essa mesma não-clausura. A cena exemplifica, de modo ambíguo, já que não se pode determinar se significa ou não, o adágio, e esse exemplifica o que acontece no texto ficcional que se tem em mãos. Allen foi atento o bastante, inclusive, para associar as resenhas que Blanchot fazia, então, em outro registro, do livro de Jean Paulhan, Les fleurs de tarbes. A questão, aqui, é a linguagem "ordinária".

O livro, resenhado com entusiasmo por Blanchot ao longo de mais de um artigo, lida especificamente com o status dos lugares-comuns da linguagem cotidiana. Para Jean Paulhan, há uma possibilidade essencial na experimentação literária com esses lugares comuns: mesmo quando o escritor não pratica o clichê, ou quando busca o maior distanciamento possível da linguagem ordinária, essa permanece sendo, em seu texto, uma possibilidade recorrente e infinita de significado, uma "refração material" que pode irromper quando o escritor menos deseja. Mesmo quando o escritor ou o leitor tomam a linguagem por plena, por

\footnotetext{
101 "Por estranha que possa parecer essa cena, ela pode referir ao ditado francês, 'o cântaro vai tanto ao poço que está quebrado', que significa algo como 'não tome as coisas por definitivas, pois pequenas alterações podem levar ao desastre', mas se é a isso que se refere é com uma ambiguidade deliberada. Já que ao aparentar retratar essa sentença Blanchot está também exemplificando-a, pois é como uma sentença que ela também sofre o risco de ser tomada por definitiva, de ser retratada de modo oco, que a deixa quebrada, inútil, também ao apresentar essa imagem Blanchot está também suspendendo seu sentido, pois quer tratemos essa cena visualmente ou verbalmente, literal ou metaforicamente, como se diz, se buscarmos seus sentido no que nos é apresentado ou em suas implicações, não há diferença" (ALLEN, MLN, p. 1111)
} 
garantida, portanto, há uma legibilidade-ilegibilidade sempre a espreitar toda e qualquer construção frasal ou semântica. Ou como escreve Blanchot na resenha elogiosa que escreveu em Faux Pas, versão menor de um ensaio que tomou a forma de livro alguns anos antes (Comment la littérature est-elle possible?, de 1942, mesmo ano em que Aminadab é publicado, assinale-se): “(...) Minha fala é ao mesmo tempo uma afirmação e uma negação do mundo inteligível, uma afirmação e um esquecimento do princípio de contradição. E o sentido da linguagem de que o papel parece ser constantemente de manifestar as coisas, quando substitui essas coisas por sua inteligibilidade, é justamente dessa contradição que ele não se separa. Tal é a função dialética do discurso, seu poder de contestação que lhe é essencial. A linguagem é ligada ao saber enquanto lhe assegura pontos fixos, uma permanência, uma determinação pelo geral, isto é, uma pausa na pesquisa apaixonada do resultado, mas ela é ligada também ao saber na medida em que pretende ligar-se ao não-saber, entranhar-se em seus retornos, rupturas, malentendidos, por uma eterna confrontação e uma eterna inversão do por e do contra, em direção a uma negação de todo princípio estável que é também uma negação dele mesmo. (...)" (BLANCHOT, 2004b, p. 108). Nessa época a noção de linguagem é elaborada em termos ainda relacionados à dialética hegeliana renovada pela fenomenologia de Kojève, mas a ideia é a mesma: encontramos na linguagem e na construção-desconstrução do sentido um movimento duplo, insolúvel, uma oscilação.

É também a questão de Mallarmé, igualmente evocada por Blanchot em uma série de textos ${ }^{102}$, em vários de seus livros. A parábola babélica dos homens enfrentando a casa, portanto, é ela mesma posta como entre parênteses pela reconfiguração do provérbio do cântaro, isto é, seu significado é tanto o sugerido pelo ditado como suspenso pela própria presença desse ditado en abyme, circunscrevendo a história, de um modo que, como veremos, se repete na ficção blanchotiana. A casa-labirinto infinita de Aminadab é uma figuração do espaçamento da narrativa, locus em que há uma dissociação quase (o quase aqui é essencial)

\footnotetext{
102 Para compreender a importância da obra de Stéphane Mallarmé e de sua noção de linguagem no conjunto da obra ensaística e ficcional de Blanchot, recomenda-se a leiturados seguintes ensaios: Le silence de Mallarmé, La poésie de Mallarmé est-elle obscure? e Mallarmé et l'art du roman, em Faux pas; Le mythe de Mallarmé, em La part du feu; L'expérience de Mallarmé, em L'espace littéraire; Une première version de Mallarmé e Ecce Liber, em Le livre à venir; Le problème de Wittgenstein e L'absence du livre, em L'entretien infini; existem outros ensaios, especialmente no volume Chroniques littéraires du jornal des débats, lançado recentemente.
} 
completa entre o sentido e seus referenciais. No momento em que os inquilinos atingem o primeiro andar, alegoria de algo como uma transcendência, ou o lugar de onde supostamente emana a lei, a única coisa que eles veem é a semelhança, ou o "mesmo", isto é, tem contato com uma estrutura iterativa, indexical, referencial, mas aberta como o próprio sentido ${ }^{103}$. A passagem a seguir demonstra nosso argumento:

Qu'ont-ils vu, qu'ont-ils fait? Ils ne surent que répéter que c'était pareil. Naturellement, pareil. Comment pour eux ces lieux interdits eussent-ils pu être différents des lieux qu'ils venaient de quitter, puisque ceux-ci mêmes leur étaient déjà défendus? Leurs yeux et leur esprit ont vu dès le premier étage se déchirer les apparences qui jusque-là avaient rendu la vie possible. Ils ont aperçu ce que nous ne voyions pas, parce que nous étions restés fidèles au précepte. À peine s'étaient-ils engagés dans les vieux chemins connus qu'ils étaient déjà réellement dans ce monde retranché où ils ne devaient pas être, ayant d'un seul pas atteint les hauteurs d'où ils ne pouvaient plus que tomber. C'est ce qui exprime leur terreur et leur folie. Dans la déraison qui les a frappés, ils se sont conduits comme des êtres raisonnables à qui leurs yeux ouverts sur des choses sans nom commandaient des actions innommables qu'ils ne purent accomplir et qu'ils remplacèrent par des actions désespérées. Leur perte même pouvait seule les consoler de ce qu'ils perdaient. - (BLANCHOT, 1972, p. 106) ${ }^{104}$

São esses mesmos hóspedes, enlouquecidos, que assumirão em definitivo a condição de espectros - ao menos alguns deles - espectros do que foram, acenando para os estranhos, fazendo-os interessarem-se pela casa, remetendo eles todos em abismo ao início do relato. Há de se estar atento, nessa passagem, não somente ao que faz sentido, isto é, a uma interpretação da passagem, mas ao que no texto é recusa à clausura do sentido, que é também recusa à leitura. É a questão da presente parábola: ela não possui um significado específico, ao menos não no

${ }^{103}$ Outros leitores estudaram a obra ficcional e ensaística de Blanchot como variações em torno do tema fundamental do deslizamento (glissement) do sentido, entre eles Gain V. Dowd, em seu ensaio "Glisser dans le vide", um dos poucos a fazer uma leitura da totalidade de Thomas l'obscur: "Fora. Neutro. Desastre. Retorno. Certamente esses nomes não formam um sistema. No que tem de abrupto, como nomes próprios que não designam ninguém, eles deslizam para fora de todo sentido possível, sem que esse deslizamento tenha ele algum sentido - ele deixa somente um semi fulgor deslizante que nada esclarece, nem mesmo o fora, cuja fronteira não é indicada em lugar algum." (DOWD, p. 153)

104 "Que viram, que fizeram? Eles não souberam senão repetir o que era parecido. Naturalmente, parecido. Como para eles esses lugares interditos tinham podido ser diferentes dos lugares que eles acabavam de deixar, por que mesmo esses já lhes eram proibidos? Seus olhos e seu espírito viram desde o rimeiro andar se despedaçarem as aparências que até ali haviam tornado a vida possível. Eles perceberam isso que nós não vemos, porque permanecíamos fiéis ao preceito. Mal tinham eles engajado nos caminhos conhecidos, já estavam realmente nesse mundo subtraído em que eles não deviam ser, tendo de um só passo atingido as alturas de onde não podiam mais que cair. É isso que exprime seu terror e sua loucura. Na desrazão que os atingiu, eles conduziram-se como seres razoáveis que com seus olhos abertos sobre as coisas sem nome comandavam ações inomeáveis que não podiam realizar e que substituíam por ações desesperadas. Sua perda somente podia consolá-los do que perdiam." 
sentido de atingir um significado pleno e único, mas também não é totalmente despida de sentido, característica que certamente pode ser estendida ao todo a ficção blanchotiana e à noção de literatura que sua obra propõe (é essa a tese, modesta, de nosso trabalho). Quando os inquilinos atravessam a linha ideal, e a loucura invade por completo suas vidas, o que penetram é esse espaço opaco e impenetrável da escritura, o espaço da fascinação ${ }^{105}$, a distância irredutível da literatura, o resto ou cinza de sentido inapropriável que é a razão de ser da literatura, se nos é permitido proferir tal absurdo.

O final do livro carrega consigo imensa ambiguidade, como de resto toda a escrita ficcional de Blanchot. Thomas termina por alcançar os sonhados andares de cima da casa, e encontra - ou pensa que encontra, inicialmente - a mulher que lhe acenou primeiramente, a dona do gesto também ambíguo que fora a razão de sua entrada na casa. Nesse momento, Thomas já é um servo - isto é, já participa inadvertidamente das leis e meandros da casa, de sua maquinaria complexa e misteriosa. A noite penetra pela janela, e com ela a escuridão. Por fim, Dom, que até então permanecera silente, começa a assemelhar-se sobremaneira com a primeira figura do romance, começa a contar a Thomas uma história, que lembra a cena que mencionamos acima. Dom diz a Thomas que foi um erro ter percorrido a via que percorreu dentro da casa, sempre em busca da verticalidade dos andares de cima.

\footnotetext{
- Quelle était cette voie?

- Vous lui avez tourné le dos, répondit le jeune homme de son air placide et un peu fat. Votre ambition, c'était de gagner les hauteurs, de passer d'un étage à l'autre, d'avancer centimètre par centimètre, comme si, à force de marcher, vous deviez nécessairement déboucher sur le toit et rejoindre la belle nature. Ambition puérile qui vous a tué tout simplement, Quelles privations n'avez-vous pas dû vous imposer! Quelles fatigues dans une atmosphère pestilentielle! Et ces récits aussi mensongers que déprimants, ces contacts d'hommes déjà décomposés par le vice! N'importe qui aurait succombé à votre place. Pourtant la vraie voie était toute tracée, elle était en pente douce et ne demandait ni effort ni consultation. De plus, elle vous conduisait vers une région où vous auriez mené une existence qui en aurait valu la peine. Là, vraiment, vous étiez chez vous.

- Et où était-ce donc? demanda Thomas les yeux à demi fermés.
}

\footnotetext{
105 “(...) Ao invés disso, o que foi descoberto é que, depois da linha ideal, há um espaço que é irredutivelmente distante; que não pode ser trazido para perto e do qual não podemos nos aproximar, e que a linha mesma, como os aventureiros descobriram, é onipresente, por isso sua pressão, quando reconhecida, exerce uma fascinação que é inescapável. Enquanto tal, essa linha passa por toda palavra, deslocando-a de modo que ela paira em um recuo que é o espaço literário: nem com sentido nem sem sentido, mas a simples opacidade de sua aparição material. Mas a experiência desta destabilização não é em nada inócua, embora após sua histeria destrutiva, o estranhamento indefinível pelo qual passa o grupo é somente o que notam os outros inquilinos."- MLN, p. 1114 (grifo nosso).
} 
- Du côté des sous-sols, dit le jeune homme d'une voix onctueuse. Je ne puis vous en parler aussi longuement qu'il le faudrait et ce n'est pas par des paroles qu'on peut faire comprendre l'inextricable beauté des caves et des souterrains. II faudrait que vous en jugiez par vous-même. Vous êtes un homme de la campagne et vous verriez tout de suite comme on se sent vivre dans ces lieux creusés en pleine terre; on y respire une odeur chaude et forte qui fait prendre en dégoût les chambres renfermées. Le plan en est très curieux: malgré le lacis des couloirs qui s'entrecroisent, bifurquent, reviennent en arrière suivant un tracé qui donne le vertige, il n'est pas possible de s'y égarer et on distingue à merveille à chaque instant l'endroit exact où l'on se trouve. D'énormes panneaux, avec un système de flèches et de pointillés, révèlent tous les dix mètres la route à suivre au milieu du dédale où l'on se croit perdu. Si l'on va à droite, on s'enfonce toujours plus loin sous les fondations; si l'on prend à gauche, on se rapproche des sous-sols et de l'entrée. C'est la seule règle qui subsiste, pour le reste on est libre.

- Libre? répéta Thomas. - (BLANCHOT, 1972, p. 212) ${ }^{106}$

Thomas devia, portanto, haver buscado o subsolo, a imanência elemental dos porões da casa. Haver decidido pela verticalidade da transcendência, buscando sempre os andares superiores, segundo Dom, foi o que o levou a tamanho e constante infortúnio em sua jornada (quase) sem sentido pela casa. O mundo do subsolo, segundo Dom, é o lugar onde são suspensas as leis da casa. É o mundo cujo limiar é guardado por Aminadab, o guardião do submundo, a dar crédito às opiniões dos inquilinos enlouquecidos, embriagados por sua leitura da maquinaria do labirinto, mas que, segundo Dom, em verdade é uma passagem totalmente transponível, que faz pensar na porta de Diante de lei de Kafka. Passagem essa que por sua vez não é exatamente uma fronteira, mas sim uma trilha que desce

106 "- Qual era essa via?

- Você virou as costas para ela, respondeu o jovem com seu ar plácido e um pouco presunçoso. Sua ambição era ganhar as alturas, passar de um andar a outro, avançar centímetro por centímetro, como se, à força de caminhar, você necessariamente chegaria ao telhado e encontrar a bela natureza. Ambição pueril que simplesmente o matou. Que privações não teria se imposto! Que fadigas numa atmosfera pestilenta! E esses récits tão mentirosos quanto deprimentes, esses contatos com homens já decompostos pelo vício! Não importa quem teria sucumbido em seu lugar. No entanto a verdadeira via estava toda traçada, ela era em suave declive e não demandava nem esforço nem consulta. Além disso, ela te conduziria a uma região em que você teria levado uma existência que teria valido a pena. Lá, sim, você estaria em casa.

- E onde era então? Questionou Thomas com os olhos semicerrados.

- Do lado do subsolo, disse o jovem com uma voz homogênea. Eu não poderia falar-lhe tão longamente quanto necessário e não é através de palavras que se poderia fazer compreender a beleza inextricável das cavernas e dos subterrâneos. Seria preciso que você julgasse por você mesmo. Você é um homem do campo e você veria rapidamente como se sente viver nesses lugares cavados em plena terra; Aí se respira um odor quente e forte que dá desgosto dos quartos isolados. A planta lá é bastante curiosa: não obstante o arabesco dos corredores que se entrecruzam, bifurcam, retornam seguindo um traçado que dá vertigem, não é possível perder-se aí e se distingue maravilhosamente a cada instante o lugar exato em que se encontra. Enormes placas, com um sistema de flechas e pontilhados, revelam a cada dez metros o caminho a seguir no meio do dédalo onde nos cremos perdidos. Se se vai à direita, penetra-se sempre mais longe sob as fundações; se se vai à esquerda, aproximamos-nos dos subsolos e da entrada. É a única regra que subsiste, para o resto se é livre.

- Livre? Repetiu Thomas." 
suavemente para dentro da escuridão, escuridão essa que - assim como o sentido, se podemos assim interpretar - não é completa e nem incômoda, mas atraente. De modo totalmente distinto da lei da casa, que buscava interferir na existência de Thomas e dos demais inquilinos, a lei - se é de lei que se trata - do subsolo é maleável, se acomodando à forma dos habitantes. Então Dom menciona um fenômeno do subsolo que encontra ecos em outras obras de Blanchot, especialmente na obra que analisamos no capítulo anterior, Thomas l'obscur, e na obra que analisaremos no capítulo próximo, La folie du jour.

\begin{abstract}
Alors, vous regardez à travers les couches qui forment un énorme amas de poussière et vous remarquez avec surprise que votre vue a changé, car vos regards, phénomène qui paraît singulier et même humiliant quand on en parle sur ces hauteurs mais qui là-bas semble beaucoup plus explicable, font penser à de fines plantes cristallisées qui auraient rapidement grandi au sein du terreau sur lequel vos yeux sont ouverts. Ce n'est pas là un prodige, contrairement à ce que croient les gens simples. Mais ce n'est pas non plus une manifestation dépourvue d'importance. Ces arborescences, tout en ne ressemblant en rien - ai-je besoin de le dire? - à de vrais arbustes, sont tout de même un signe de la forme élevée d'union qu'il y a entre vous et le milieu où se façonne votre vie. De même que la nuit fait étinceler les regards pour en tirer des images vraiment nocturnes, de même la terre les fait fructifier sous les seules formes qu'il lui soit permis de répandre et dans lesquelles elle met son amour; certains se servent d'une comparaison pour expliquer ce phénomène, ils disent que cette terre où vous vous trouvez est une nuit solide et que de vos yeux naissent des plantes et des ombelles pour que la nature puisse mieux jouir de l'acte qui la traverse, comme il arrive que des yeux de la femme qu'il chérit l'homme qui a étudié la loi voit sortir des jugements et des sentences. Mais peu importe. Le fait est là et vous en ressentez une grande satisfaction. II vous semble qu'un tel changement annonce le retour d'une époque totalement révolue, dont vous n'avez même pas gardé le souvenir, tant elle se perd dans un lointain fabuleux. - (BLANCHOT, 1972, p. 214215) ${ }^{107}$
\end{abstract}

Esse acontecimento bizarro, em que a visão muda como se, ao contato da

terra escura, houvessem-Ihe crescido ramificações de cristal, espécie de

\footnotetext{
107 "Agora, você veja através das camadas que formam um enorme pilha de moeira e você perceba com surpresa que sua visão mudou, pois vossos olhares, fenômeno que parece singular e mesmo humilhante quando se fala sobre essas alturas, mas que lá embaixo parece muito mais explicável, faz pensar em finas plantas cristalizadas que teriam rapidamente crescido no seio do humus sobre os quais seus olhos estão abertos. Isso não é lá um prodígio, contrariamente ao que creem as pessoas simples. Mas isso não é também uma manifestação desprovida de importância. Essas arborescências, ao mesmo tempo que não se assemelham em nada - tenho necessidade de dizê-lo? - com verdadeiros arbustos, são certamente um signo da forma elevada de união que há entre você e o meio em que se modela sua vida. Assim como a noite faz reluzir os olhares para deles retirar imagens verdadeiramente noturnas, do mesmo modo a terra os faz frutificar sob as únicas formas que Ihe são permitidas espalhar e nas quais deposita seu amor. Alguns se servem de uma comparação para explicar esse fenômeno, eles dizem que esta terra em que você se encontra é uma noite sólida e que de seus olhos nascem plantas e flores para que a natureza possa melhor gozar do ato que a atravessa, como acontece de dos olhos da fêmea que o homem que estudou aprecia saírem julgamentos e sentenças. Mas pouco importa. O fato está aí e você ressente uma grande satisfação. Parece-lhe que uma tal mudança anuncia o retorno de uma época totalmente passada, da qual você não guardou mesmo a lembrança, tanto ela se perde num longínquo fabuloso."
} 
materialização da visão, fenômeno que Dom faz questão de dizer que é real e perfeitamente explicável, um símbolo da contiguidade entre o ser de quem o habita e o ser do subsolo. Essa é a forma das imagens geradas pela terra na visão: nascidas do próprio oculum, se tornam um olhar-em-arbusto, imagem que aparecerá em outros momentos centrais da obra ficcional de Blanchot. Visão densa, material, capaz da visão partilhando do mesmo meio em que está imersa.

Essa transformação hipotética - dado que, afinal, Thomas não seguiu os conselhos de Dom, que de resto também só o ofertou quando já era, talvez, tarde demais - faz pensar no episódio que mencionamos de Thomas l'obscur, em que a própria cegueira de Thomas é o que lhe permite ver, em que a visão falha de modo a permitir que Thomas enxergue a única coisa passível do olhar. A única mudança, e William S. Allen foi um dos intérpretes que a perceberam, é de um registro noturno a um registro ctônico (embora em Thomas l'obscur houvesse também uma caverna), embora haja uma radicalização aparente do movimento, já que aqui a visão se confunde com a própria terra. Como em outros episódios da literatura blanchotiana, há um olho invadido, um olho obliterado: em Thomas l'obscur toda a imanência do mar passa pelo olho de Thomas, e mesmo um homem; em Aminadab, temos essa visão ctônica do olho se ramificando em sua materialidade, ainda na imanência da terra. Dom, no entanto, avisa Thomas que ele pode não estar preparado para a visão e para a permanência no fora do dia após passar pelo subsolo, após passar por baixo da terra. Thomas, enfim, seguindo seu ceticismo que mencionamos anteriormente, acaba por não se decidir, diz que é tarde demais para que a transformação seja ainda uma opção. A luz, afinal, sempre foi um sinal relacionado à confusão, em toda a extensão de Aminadab, essa luz ambígua, que dá a entender um sentido possível, de modo diametralmente distinto da escuridão, que não lança mão desse artifício. Thomas começa a ver mais claramente perto do fim do livro, quando a escuridão invade os cômodos.

No fim - se podemos falar de um fim nesse roman-en-abyme que é Aminadab-, quando finalmente Dom e a mulher começam a dirigir-se a Thomas aparentemente de modo a esclarecer sua situação, a auxiliá-lo nos meandros da casa, ambos acabam por dissolver na escuridão, junto com Thomas. O que resta, afinal, é a espera e a aproximação do sentido, e com ele do sentido final do livro. Thomas termina por perguntar, e é a última linha do livro: "quem é você"?, mostrando que nada foi aprendido, que nenhum sentido chegou a se fazer presente, 
se não enquanto distanciamento da imagem, senão enquanto indiferença absoluta da imagem. Thomas não realiza nada em suas andanças pela casa; a mulher que acenou, no gesto ambíguo que o levou a entrar, não era a mesma; assim como o aceno não era um chamado, a mulher era outra, como a outra mulher revela perto do fim, mas não somente isso; era outro também que ela esperava no lugar de Thomas. Tudo que Thomas encontrou, quando procurava o sentido da lei e a lei do sentido da casa, foi a confusão e o equívoco, que era também como o recebiam quando ele tentava explicar seus propósitos aos seus interlocutores. A recusa constante de Thomas em aceitar as explicações e as narrativas dos habitantes da casa implica na sua insistência na busca por um sentido, pois não é possível que não haja ao menos um arremedo de propósito ou sentido a que os habitantes, os funcionários, alguém se atenha no estranho mundo de Aminadab.

A narrativa possui, portanto, ao menos três ou quatro mise en abyme do tipo que buscamos aqui descrever, em que não dada ao leitor a possibilidade de discernimento de um extrato semântico dos demais. Uma das hipóteses aventadas por diversos dos leitores de Blanchot, entre eles Christophe Bident ${ }^{108}$, na biografia que dedicou à obra blanchotiana, é a de que Aminadab representa, de certo modo, a passagem do registro do romance ao registro do récit, modificação de uso dos recursos literários que Blanchot levaria a cabo nos anos que viriam, com a publicação da segunda versão de Thomas l'obscur em 1950, e de L'arrêt de mort (narrativa condensada, mais curta etc.) em 1948. Gostaríamos de sugerir, doutro modo, que há uma continuidade de fundo na ficção de Blanchot, ao menos no que diz respeito ao uso dessa mise en abyme transfigurada com que lidamos. Trata-se de um dos recursos utilizados com mais frequência por Blanchot, como veremos no capítulo a seguir, em que analisaremos uma narrativa que representa, de certo modo, também uma inflexão no status ontológico da ficção, além de uma sofisticação maior no emprego desse artifício: La folie du jour, publicada primeiramente na revista Empédocle em 1949 com o título "Un récit", e posteriormente em formato de livro, em 1973, ano também da publicação de Le pas au-delà. Consequência, também, como deve ser assinalado, da tentativa sempre renovada, da parte de Blanchot, de escrever textos capazes de permanecer alheios a qualquer recuperação interpretativa, a qualquer leitura, textos que, contudo,

${ }^{108}$ BIDENT, Christophe. Maurice Blanchot, partenaire invisible, p. 207. 
podem ser lidos, passíveis de leitura. "Neither meaningful nor meaningless", precisamente, como diz a expressão e como índice da inexorabilidade do próprio sentido. Há uma revelação na voz até então muda de Dom, quando diz a Thomas que em verdade ele tomou o caminho errado, mas a revelação nada revela, é um segredo de polichinelo. Que no entanto é: essa é talvez a lição maior da fiç̧ão blanchotiana. Deve ser lembrado, igualmente, o fato de que Aminadab, afinal - título do livro que se tem em mãos - é também o nome de um guardião ctônico que não existe, "fruto da imaginação" dos hóspedes da casa. Como a complexa rede de referências que o nome de Aminadab sugere, o sentido funciona, em Blanchot, como esse excesso lacunar, essa interrupção da linhagem e da genealogia. 
Capítulo V - O abismo do dia 
O próximo texto que pretendemos analisar do ponto de vista da questão do sentido é La folie du jour, tido por parte da crítica como um dos experimentos narrativos mais radicais de Blanchot. Esse texto, não muito conhecido no Brasil ${ }^{109}$, teve um impacto considerável na obra de Jacques Derrida, e é analisado por ele mesmo em diversos textos, entre eles Survivre, Titre-à préciser, La loi du genre e outros, textos fundamentais também para a compreensão atual dos dispostivos e artifícios presentes no texto. Antes de tudo é necessário de introduzir a relação que essa narrativa contém com uma certa ideia da literatura, do que seria o "fenômeno" da literatura, e com o que a literatura pode trazer de radical para a filosofia, especialmente para a filosofia fenomenológica.

Partimos do princípio de que não se pode dizer o que é intrinsecamente literário nos textos literários, mas que há de fato certa potência de ficção em qualquer texto, e especialmente, talvez, em alguns textos ditos literários. Essa potência está relacionada, no que se conveio chamar literatura, à capacidade de suspensão, de suspense, por assim dizer, que a linguagem literária pode fazer irromper em qualquer texto, mas também uma experiência não necessariamente atingível por outros tipos de discurso, como o discurso filosófico, político, histórico, jurídico, etc. Essa experiência, é necessário dizer, está nos textos que buscam pensar - e pensar aqui não se confunde (somente, ao menos) com a lógica argumentativa, da predicação, com ideias expostas segundo certos protocolos imutáveis, mas com as conformações e configurações do próprio texto, isto é, falamos de um pensamento que pensa textualmente, e em que o texto, as reviravoltas e deslizamentos do texto são o foco das modificações - sua própria possibilidade, isso nos textos capazes de colocar em questão, evidentemente, sua própria possibilidade. Algo dessa preocupação formal foi herdada da obra de Blanchot por Jacques Derrida, para quem o acontecimento da literatura está relacionado a essa capacidade formal, essa capacidade do texto de introduzir a crise na nossa noção fenomenológica da obra, de tornar instável nossa relação com o mundo visível, com a verdade, a metafísica e a visibilidade.

\footnotetext{
${ }^{109}$ Há um projeto do Grupo de Estudos Blanchotianos e de Pensamento do Fora do CNPq, liderado por Eclair Antônio Almeida Filho, professor do LET-UnB, em curso, cujo propósito é traduzir e publicar no Brasil as principais narrativas de Maurice Blanchot, entre elas Thomas l'obscur (roman, de 1941), Aminadab (1942), Le très-haut e L'arrêt de mort (1948), La folie du jour (1949) e a segunda versão de Thomas l'obscur (1950). Atualmente estão sendo negociados os direitos de reprodução e tradução das obras.
} 
Assinalados esses precedentes, passemos à análise do texto em questão, importante e essencial não somente no quadro geral da obra de Blanchot, mas para o entendimento da literatura que se possui hoje no âmbito da crítica literária de matriz europeia. La folie du jour, título que poderíamos traduzir, assumindo uma perda infinita que por si só diz muito sobre a própria inapropriabilidade desse texto, por A Loucura do dia. Como de costume, o título já contém uma tentativa formal, textual e extra-textual, de trazer a instabilidade para o âmbito da ficção, que merece ser analisada, dada a pouca repercussão desse texto entre os leitores de Blanchot existentes no Brasil, inclusive.

La folie du jour é um texto sobre a exigência do texto. É uma narrativa, relatada por um narrador, em primeira pessoa, uma situação em que uma voz conta uma história. Até aí não há nada digno de atenção, que a diferencie de outras narrativas do mesmo tipo. Ao longo da história, entretanto, esse quase-narrador personagem aparentemente satisfeito com a realidade, alguém para quem bastam as correspondências da vida cotidiana, alguém, enfim, para quem as palavras de fato são capazes de produzir sentidos inexoráveis, e alguém, por fim, que se define como escritor, como produtor de narrativas (e alguém que não chega nunca a constituir sequer um narrador, como veremos adiante) - é atingido por cacos de vidro, que the impõem uma obstrução entre os olhos e a luz, entre a visão e o dia. Como vimos anteriormente em Thomas l'obscur e Aminadab, essa cena da introjeção da visão é recorrente em Blanchot.

Com isso, rompe-se a correlação entre o que se vê e o que se espera ver, entre o que se vê e o que se relata: o âmbito absoluto do ser em que ele mesmo basta ao ente é então interrompido, e o narrador vê-se tomado pela "loucura", que até aqui permanece inexplicada, mas que mais adiante saberemos tratar-se da "loucura do dia". Ao longo da narrativa o narrador é internado. Vozes autoritárias, médicas interpelam-no, perseguem-no fazendo uma exigência, somente: que seja capaz de constituir um relato sobre o que lhe aconteceu, que faça do trauma da visão - da disjunção inaugurada por esse trauma - um acontecimento narrativo, que aja como esperado e faça do acontecimento do trauma um relato, do trauma récit.

Então, em uma tentativa de responder às autoridades, e não somente das autoridades, mas de corresponder às expectativas do leitor, que nesse caso também espera, como seria "natural", que o narrador seja capaz de transformar o acontecimento da disjunção entre acontecimento e relato em relato do 
acontecimento, o narrador acaba por fazer uma afirmação que desordena todo o espectro do texto. É então que o leitor desse relato de Blanchot choca-se com o fato surpreendente - com a confissão, talvez - de que o texto que tem em mãos é o relato extorquido do narrador, é o texto que lê desde o começo, é o livro que tem em mãos. Situação enigmática e que requer um desdobramento, um aprofundamento da mise en abyme, que analisamos algo apressadamente, dada a sua presença constante na obra de Blanchot, como buscamos demonstrar, e que analisaremos com mais calma agora.

A mise en abyme é compreendida, ao menos pra um de seus principais estudiosos, Lucien Dällenbach ${ }^{110}$, como o conjunto de três elementos: o tornar presente situado na diegese do produtor ou receptor da narrativa; a revelação da produção ou da reprodução per se; e a explicitação do contexto que determina essas produção e recepção do texto. Se há um traço comum aos três elementos, poderíamos resumi-lo com a seguinte sentença: "tornar visível o invisível', tornar visíveis os mecanismos supostamente subjacentes à experiência, ao espaço literário como tal, à produção textual do acontecimento literário (é importante guardar essa sentença, porque ela é curiosamente oposta à visão de outro pensador sobre a literatura, pensador influenciado e mais próximo de Blanchot).

Além disso, a mise en abyme está associada diretamente ao mecanismo da doação presente na obra, na relação da obra com o ser, como podemos ver nos trípticos do medievo ao quatrocentto italiano, em que muitas vezes surge a figura do doador, ostentando uma pequena reprodução da obra, garantindo assim que a figura do mecenas-provedor, origem e possibilidade da obra seja também nela representada. Michel Foucault, um desses pensadores para quem a literatura tem algo essencial a modificar na própria filosofia, e de quem gostaríamos de lembrar aqui alguns trechos, chamava atenção para a importância desses momentos de reduplicação no texto literário, ou de "auto-representação da linguagem", centrais, como vimos, não somente para a obra ficcional de Blanchot, mas para a constituição do próprio ser da obra literária de todos os tempos:

\footnotetext{
${ }^{110}$ Não encontramos em nossas pesquisas nenhum estudo de fôlego tão abrangente quanto Le récit speculaire, o livro já antigo de Lucien Dällenbach a que fazemos referência, além dos escritos de André Gide e alguns poucos outros a que esse estudo faz referência. A presença da mise en abyme, contudo, em grande parte dos textos ditos 'literários' nos convence por si só da importância do fenômeno.
} 
(...) Pergunto-me se não seria possível fazer, ou pelo menos esboçar, a distância, uma ontologia da literatura a partir desses fenômenos de auto-representação da linguagem: tais figuras, que são aparentemente da ordem do artifício ou da diversão, escondem, ou melhor, traem, a relação que a linguagem mantém com a morte - com esse limite para o qual ela se dirige e contra o qual ela é construída. Seria preciso começar por uma analítica geral de todas as formas de reduplicação da linguagem das quais se podem encontrar exemplos na literatura ocidental. Essas formas, sem dúvida alguma, são em número finito, e delas se deve poder construir o quadro universal. Frequentemente, sua extrema discrição, o fato de que elas são às vezes escondidas e lançadas aí como por acaso ou inadvertência não devem provocar ilusão: ou melhor, é preciso reconhecer nelas o próprio poder da ilusão, a possibilidade para a linguagem (cadeia monocórdia) de se manter de pé como uma obra. A reduplicação da linguagem, mesmo quando ela é secreta, é constitutiva do seu ser como obra, e os signos que nela podem aparecer, é preciso lê-los como indicações ontológicas. - (FOUCAULT, 2001, p. 50) ${ }^{11}$

Provavelmente Maurice Blanchot, de quem buscamos delinear os principais artifícios presentes em suas ficções, não subscreveria, queremos acreditar, essa tentativa de formular uma ontologia da obra de arte, em especial da literatura, cuja essência, disse mais de uma vez, é furtar-se à toda essencialização; e o que encontramos em La folie du jour, em verdade, é um mecanismo que se assemelha a uma mise en abyme, mas que não se limita a denunciar o espaço da arte, e assim participar da construção de sua ontologia, mas, como o mesmo Michel Foucault diz da ficção de Blanchot em outro texto, dedicado esse especialmente às ficções de Blanchot ${ }^{112}$, e talvez mais atento ao movimento que buscamos aqui descrever," $A$ ficção consiste, portanto, não em mostrar o invisível, mas em mostrar o quanto é invisível a visibilidade do visível" (FOUCAULT, 2001, p. 224-225). Diametralmente opostas, as sentenças de Dällenbach e de Foucault dizem muito sobre o uso da mise en abyme efetuado por Blanchot, em La folie du jour e nos demais textos de sua ficção, especialmente os que analisamos.

Há uma constante aqui, tanto no que diz respeito a essa narrativa em especial quanto ao conjunto da obra ficcional de Blanchot. Pois, segundo diz Derrida em um de seus ensaios sobre La folie du jour e sobre a escritura de Blanchot, o récit, e esse récit em especial, volta-se contra o dogma da antiga lógica platônica do visível: a visibilidade não deve ser visível, e o que torna visível é invisível por princípio. O texto deve omitir que é um texto, assim como o pintor omite tanto quanto possível as

${ }^{111}$ FOUCAULT, Michel. Ditos e Escritos. Vol. 3: Estética: Literatura e Pintura, Música e Cinema. Rio de Janeiro: Forense Universitária, 2001. p. 50. A mise en abyme parece encontrar-se na literatura de todos os tempos, e os exemplos são infindos. Não os mencionaremos exaustivamente aqui, basta lembrar alguns dos mais famosos: a peça dentro da peça de Hamlet; a noite a mais nas Mil e uma noites; o relato das aventuras de Odisseu diante dos feácios, na Odisseia; entre outros.

${ }^{112}$ La pensée du dehors, presente em Revue Critique, 1966, p. 523. 
pinceladas que evidenciam que se trata de um quadro, de uma imitação, em fim. Citamos Derrida:

La folie du jour é uma história da loucura em que consiste ver o dia, em ver a visão ou a visibilidade a partir de uma experiência de cegueira. (...) Ver a visão, sobrever, esta loucura abissal de uma cena absolutamente primitiva, esta cena da cena, se simula e se dissimula no récit de forma tranquilizadora, para quem quer tranquilizar-se, de espetáculos circunscritos, de 'visões' ou de 'cenas' determinadas que vêm de algum modo alegorizar o abismo e conter a loucura. (DERRIDA, 1986, p. 137) ${ }^{113}$

Ainda seguindo o quadro de definições de Dällenbach, existem três tipos de mise en abyme: a reflexão simples, a reflexão ao infinito e a reflexão paradoxal. Todas dizem respeito a uma tentativa, por vezes frutífera, de tornar óbvia a ficcionalidade do texto primeiro, pela inserção de um texto segundo que com ele apresenta uma relação de similitude, seja qual for. Isso acontece de três modos: o primeiro, derivado da heráldica, a arte dos brasões, contém uma duplicação simples, uma replicação de segundo nível da narrativa principal; o segundo - que como foi dito é chamado de "reflexão ao infinito" - traz uma confusão suplementar: um relato contém um relato que contém um relato que contém um relato, empregando um jogo de espelhos, ao infinito. Há ainda o terceiro tipo, mencionado, o da "reflexão paradoxal", em que as narrativas inseridas uma dentro da outra se confundem, não permitindo que o leitor diferencie de forma definitiva o interior e o exterior do relato.

A princípio, poderíamos enquadrar La folie du jour nesse terceiro tipo de reflexão descrito por Dällenbach, também chamado de aporístico. Mas a radicalidade desse texto não se limita à confusão que causa no leitor, não permitindo que diferencie o relato que lê do relato "en abîme". La folie du jour decerto é uma narrativa sobre a impossibilidade de narrativa, como mencionamos; mas é também um texto sobre a citação, sobre um certo estatuto da citação, ou uma "mise en abyme de l'abîme", expressão que Derrida emprega em outro texto, mas de ressonâncias semelhantes no que aqui nos interessa ${ }^{114}$. Assim começa o breve relato de Blanchot (ou, para utilizar os termos de Derrida, essa é sua borda superior):

113 DERRIDA, Jacques. "Survivre”. In: Parages. Paris: Galilée, 1986, p. 137
114 DERRIDA, Jacques. Les Yeux de la langue. Paris: L’Herne, 2005, p. 27. 
Je ne suis ni savant ni ignorant. J'ai connu des joies. C'est trop peu dire: je vis, et cette vie me fait le plaisir le plus grand. Alors, la mort? Quand je mourrai (peut-être tout à l'heure), je connaîtrai un plaisir immense. Je ne parle pas de l'avant-goût de la mort qui est fade et souvent désagréable. Souffrir est abrutissant. Mais telle est la vérité remarquable dont je suis sûr: j'éprouve à vivre um plaisir sans limites et j'aurai à mourir une satisfaction sans limites. (BLANCHOT, 2006, p. 9) ${ }^{115}$

Assim começa o relato, a narrativa La folie du jour. Esse trecho de texto, o início do que aparenta ser testemunho, compõe o que se chama inadvertidamente de início do texto, ou de "borda" ou limite superior do texto. Lendo o testemunho, presenciamos o relato, temos a impressão algo vaga de um acontecimento. Como mencionamos, alguém se debate com a lei, e também com estranhas autoridades que exigem desse alguém, dessa voz um relato, um texto, como mencionamos, exigem que o narrador - ou a voz narrativa que não chega a constituir-se enquanto tal - dê conta dos fatos, dê notícia dos fatos, componha uma narrativa do testemunho desses fatos: diga o que realmente aconteceu, é o que as autoridades Ihe exigem. Se a história parece carecer de detalhes, é porque realmente carece, sendo exígua de qualquer minúcia a respeito das motivações do narrador ou dos médicos: o narrador realmente limita-se a um breve testemunho, do que aparenta ser uma vida normal, ainda que traumatizada pelo incidente mencionado, em que the jogam vidro nos olhos, o trauma, enfim.

A partir desse momento o relato torna-se algo confuso, como se esse acidente - um acidente da visão, assinale-se, em que o vidro é introjetado nos olhos do narrador - houvesse imposto uma disjunção entre a visão, a totalidade da visão, e o relato, ou a narrativa, houvesse imposto a loucura entre o relato e o testemunho. É então que o leitor é surpreendido pela rendição dessa voz narrativa, desse narrador que de súbito sucumbe ao desejo das autoridades:

On m'avait demandé: Racontez-nous comment les choses se sont passées "au juste". - Un récit? Je commençai: Je ne suis ni savant ni ignorant. J'ai connu des joies. C'est trop peu dire. Je leur racontai l'histoire tout entière qu'ils écoutaient, me semble-t-il, avec intérêt, du moins au début. Mais la fin fut pour nous une commune surprise. "Après ce commencement, disaient-ils, vous en viendrez aux faits." Comment cela! Le récit était terminé. (BLANCHOT, 2006, p. 29) ${ }^{116}$

\footnotetext{
115 "Não sou nem sábio nem ignorante. Conheci alegrias. É dizer muito pouco: estou vivo, e essa vida me dá o maior dos prazeres. Então, a morte? Quando morrer (talvez a qualquer momento), sentirei um prazer imenso. Não falo do antegosto da morte, que é insípido e, no mais das vezes, desagradável. Sofrer embrutece. Mas tal é a verdade notável da qual estou certo: provo no viver um prazer sem limites e teria em morrer uma satisfação sem limites."

116 "Haviam me pedido: Nos conte como as coisas se passaram "de fato" . - Um relato [um récit]? Eu começava: Não sou nem sábio nem ignorante. Conheci alegrias. É dizer muito pouco. Eu lhes
} 
Essa estranha estrutura, semelhante a outras que assinalamos nos textos de Blanchot, que à primeira vista assemelha-se a uma mise en abyme aporística, uma especificação da mise en abyme do tipo reflexivo, a seguir-se a tipologia descrita por Dällenbach - cria um espaço narrativo totalmente diferente de uma mise en abyme do tipo reflexivo - como a presente no Les faux-monnayeurs de André Gide, para citar um exemplo razoavelmente conhecido - ou do tipo da duplicação simples - a peça dentro da peça no Hamlet de Shakespeare. Ali talvez a duplicação diga mesmo respeito ao denunciar o espaço ficcional da obra, a criar na obra substrato que denuncie seu espaço, fazendo cumprir a função preconizada pela ontologia heideggeriana da obra de arte, de mostrar que "ali houve ser", "ali fez-se ente", essa função de interrupção do circuito do mundo imaginada pelo Heidegger do ensaio sobre A Origem da obra de Arte ${ }^{117}$. Mas em Blanchot, como buscamos demonstrar ao longo do presente texto, trata-se de uma situação completamente diferente, pois a passagem de um nível da diegese a outro - chame-se-a de prolepse ou por qualquer outro nome - não é tão simples em seus textos ficcionais: aqui não é mais possível dizer qual relato é o original e qual relato é dele uma mera derivação, pois não se sabe se o começo - a borda ou limite superior do texto - é uma citação do texto final, ou se o texto final é uma citação do texto inicial. O leitor é assim silenciosamente levado a recomeçar o relato, o que torna a leitura do mesmo potencial e estruturalmente infinita. Jamais o leitor pode afirmar em definitivo o que lê, se se trata do relato inicial ou do relato extorquido, por um motivo bastante simples: aqui a mise en abyme não tem a função estrutural de tornar evidente o espaço da obra, ou o fato de que há obra, somente, mas sim a de tornar confusos os limites entre a vida e a obra, entre o relato e o testemunho, ou, pelo menos, entre o texto de Blanchot e os textos nele intricados, entre o próprio texto e a cadeia infinita de textos que o suplementam.

Gostaria de lembrar aqui algumas palavras sobre a obra de Blanchot e sobre sua concepção do espaço literário que também sugerem as implicações que ecoam no procedimento iterativo empregado em La folie du jour, em Thomas l'obscur e em Aminadab, mas especialmente no texto que agora analisamos:

contava a história inteira, que eles escutavam, me parece, com interesse, ao menos no início. Mas o fim foi para nós uma surpresa comum. "Depois desse começo, diziam, você virá até os fatos." Como assim? O relato terminara."

${ }^{117}$ HEIDEGGER, Martin. A origem da obra de arte. 
O espaço literário a que nos conduz Blanchot (quem tampouco admite, ao menos de uma maneira explícita, as preocupações éticas) não tem nada em comum com o mundo heideggeriano que a arte faz habitável. Segundo Blanchot, a arte, longe de esclarecer o mundo, deixa perceber o subsolo desolado, cerrado à toda luz, que o sustenta, dá à nossa estância sua essência de exílio, e às maravilhas de nossa arquitetura sua função de cabanas no deserto. Para Blanchot, como para Heidegger, a arte não conduz (ao contrário da estética clássica) a um mundo atrás do mundo, a um mundo ideal atrás do mundo real. A arte é luz. Luz que para Heidegger vem do alto criando o mundo, fundando o lugar. Negra luz para Blanchot, noite que vem de baixo, luz que desfaz o mundo reconduzindo-o à sua origem, à reverberação, ao murmúrio, ao rumor incessante, a um 'profundo antanho, antanho jamais esgotado'. - (LEVINAS, 2000, p. 43) $)^{118}$

É a essa noite que vem de baixo, à repetição incessante desse "profundo antanho" que os textos ficcionais de Blanchot busca responder. E essa estrutura semelhante, mas não exatamente análoga, à mise en abyme que cria um efeito de estranhamento, e prende o leitor no recomeço, um pouco à maneira do instante, pensado como aresta ou aporia em vários textos de Derrida: o récit torna-se ficção do acontecimento sobre o qual não se pode permanecer, ou o próprio acontecimento, como diz Blanchot no Le livre à venir, não somente relato do acontecimento. A complicação citacional analisada por Derrida, artifício construído justamente de modo a impedir o leitor de discernir que texto é citado e que texto é a citação, dá origem a esse espaço de estranhamento que é o espaço literário. Como diz Derrida no ensaio que citamos alguns momentos atrás, fundamental para a compreensão desse dispostivo ficcional:

(...) São as mesmas palavras, na mesma ordem, mas não é uma citação no sentido restrito, pois, sem aspas, isso começa ou recomeça um quase-relato que novamente engendrará toda a sequência compreendendo esse novo início, etc. $O$ que vem depois da palavra 'récit' e seu ponto de interrogação, o que inicia o começo de relato extorquido pelos representantes da lei, essas primeiras palavras ('Eu não sou sábio nem ignorante...') marcam assim um colapso impensável, irrepresentável, insituável na ordem linear de uma sucessão, em uma sequencialidade espacial ou temporal, em uma topologia ou uma cronologia objetiváveis. (DERRIDA, 1986b, p. 270-271) ${ }^{119}$

E mais adiante:

Esse parágrafo inaugural (borda superior de La folie...), saberemos mais tarde, na penúltima página, que ele se confunde, em seu conteúdo e sua forma, senão em seu acontecimento, com o início do récit que o narrador tenta iniciar, à demanda

\footnotetext{
${ }^{118}$ LEVINAS, Emmanuel. “La Mirada del Poeta”. In: Sobre Mauricio Blanchot. Madrid: Trotta, 2000. p. 43.

${ }^{119}$ DERRIDA, Jacques. “La Loi du Genre”. In: Parages. Paris: Galilée, 1986, p. 270-271.
} 
pressionante de seus questionadores. Isso forma um espaço muito estranho: o que se dava como o começo e a borda superior de um discurso não terá sido senão a parte de um récit que faz parte do discurso enquanto aquele conta como tentou-se extorquir - em vão! - um récit do narrador. A borda inicial terá sido a citação a princípio inaparente de um pedaço de récit que ele mesmo não fará senão citar sua citação. Tantas citações, de citações de ré-cit-ações sem performance originária, sem speech act que não sejá já a iteração de um outro: sem círculo e sem aspas para nos assegurar quanto à identidade, à oposição ou à distinção dos acontecimentos discursivos. A parte é sempre maior que o todo, a borda do conjunto é uma dobra no conjunto. [grifo nosso] - (DERRIDA, 1986b, p. $141-142)^{120}$.

Essa privação do texto de toda "borda" ou limite superior, pois a borda superior do texto cria um "bolso" no interior do próprio texto, em que a borda funciona e não funciona como borda, como limite do texto, é ela que permite e não permite o pertencimento do texto que se lê a um complexo regime jurídico e metafísico, delimitando, de certo modo, o início do texto, mas ao mesmo tempo evitando a todo custo fazê-lo. E não é somente o caso do relato, o caso da mise en abyme do relato. Há um efeito estrutural bífide, que vai além da da mise en abyme autorepresentativa do récit como um todo, estrutura que Derrida chamou algo inventivamente em Parages e em seus seminários sobre a obra de Blanchot de "dupla invaginação quiasmática", por conta dos bolsos de citações que cria no texto ${ }^{121}$.

O dispositivo funciona grosso modo da seguinte forma: quando, no antepenúltimo parágrafo do récit, as citadas "autoridades" exigem do narrador que dê seu relato, que conte as coisas como se passaram "au juste", o narrador responde: "Um relato?" antes da citação do início do relato: "Não sou sábio nem ignorante. Tive alegrias (...)", ao que responde, logo após o início do relato en abyme, frase que viria a ser bastante conhecida: "Un récit? Non, pas de récit, plus jamais." O final nega o que acaba de acontecer no texto, isto é, é formulado o artifício de um final, mas o final não chega a acontecer, assim como o começo não

\footnotetext{
120 DERRIDA, 1986, p. 141-142.

121 Esse dispositivo, chamado por Derrida de dupla invaginação quiasmática, traz consigo a lembrança de outras topologias insólitas - como o spiral gyre de Yeats e a fita de Moebius -, de certos conceitos que surgem, por exemplo, na literatura de Jorge Luis Borges: o de números transfinitos. Esses números (aos quais Borges faz alusão especialmente no Aleph), descobertos por Georg Cantor, são de tal forma gigantescos - abissais, poderíamos exagerá-lo - que neles o todo não é maior que algumas de suas partes. O Aleph é justamente isso: "para o Mengenlehre, é o símbolo dos números transfinitos, nos quais o todo não é maior que qualquer das partes." Poder-se-ia talvez aventar a hipótese de que a ficção de Blanchot responde às necessidades ficcionais de uma filosofia que já contempla a ideia de infinitos diversos. Derrida concorda, como se pode depreender da citação acima, que La folie du jour é um texto em que "a parte é sempre maior que o todo"; não confirmamos a hipótese, mas gostaríamos de deixá-la em aberto.
} 
chega a acontecer, pois confunde-se com o relato extorquido de alguém que supostamente era incapaz de relatar, de atar às palavras as coisas. Essa estrutura, como vimos, é central tanto em Thomas l'obscur quanto em Aminadab, embora constitua-se de maneira mais densa e direta em La folie du jour. A consequência é que, ainda segundo Derrida:

Não há senão conteúdo sem borda, e não há senão borda sem conteúdo. A
inclusão (ou a oclusão, a invaginação oclusiva) é interminável, é uma análise do
récit que não pode senão dar a volta, impossível de deter, inenarrável e
insaciavelmente repetitiva - mas terrível para aqueles que em nome da lei
requerem que a a ordem reine no relato e que querem saber, com toda a
competência requerida, como isso se passa 'de fato' [au juste]. Pois se 'eu' ou 'ele'
continuasse a contar o que contou, não terminaria de retornar a esse ponto e de
recomeçar a começar, isto é, a recomeçar por um fim que precede o início. E do
ponto de vista do espaço-tempo objetivo, o ponto em que ele se detém é
absolutamente inassinalável ('Eu lhes contava a história inteira...') pois não há
história 'inteira' fora daquela que assim se interrompe. ${ }^{22}$

À ocorrência da mise en abyme primeira, mais óbvia para o leitor, que trazia o colapso da borda superior do texto, corresponde essa segunda mise en abyme, que faz ruir também a borda inferior do texto. Derrida comparou essa estrutura em dupla hélice a duas bocas abertas, entrecruzadas, que criam um espaço citativo dentro do texto, fazendo-o oscilar indefinidamente, e tornando sua leitura estruturalmente infinita. Como no desenho abaixo, supostamente desenhado em um de seus seminários ${ }^{123}$ dos anos de 1970 que lidavam com as ficções de Blanchot:

A "Je ne suis ni savant ni ignorant... "
B. "Un récit? Je commençai:
A'. Je ne suis ni savant ni ignorant... »
B'. "Un récit? Non, pas de récit, plus jamais. »

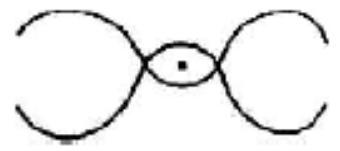

A narrativa, portanto, foi contada à altura desse segundo entrelaçar de citações; mas a negação da narrativa - o "pas de récit" que cita a própria noção de récit, mostrando, justa e novamente, o que está em questão nesse texto -, com sua recusa, impede um relato que não havia começado de fato (pois era de uma citação que se tratava, ainda que não o soubéssemos) de terminar efetivamente. $E$, mais curiosamente ainda, $\mathrm{O}$ "pas de récit, plus jamais" refere-se ao futuro, mas refere-se, 
na confusa estrutura em dupla hélice de La folie du jour, ao passado do relato que acaba de ser relatado, assim como o início do texto, que embora refira-se ao passado, não pode fazer referência efetiva a um acontecimento de fato. O "pas de récit", de modo frontal, contraria a própria história, o próprio relato contado: poderse-ia dizer, portanto, que a história foi e não foi contada, ou que, contada, foi o relato de sua própria dissolução. Esse texto, a exemplo de outros textos ficcionais de Blanchot, como buscamos assinalar, cria, assim, dobras, dobras que impedem que se diga o que é parte e o que é todo, o que é citado e o que é citação, e, principalmente, se houve ou não houve récit, e se a promessa de não se fazer o relato foi de fato cumprida - a impossibilidade ficcional que assombra cada testemunho, para entrar brevemente em outro aspecto caro às leituras de Derrida e Blanchot - no instante indecisivo. Do instante dessa aporia - pois só as há instantaneamente, elocubrando, endereçando, evocando o instante - o relato, através da complexa estrutura de que tentamos dar a descrição mais simples o possível, exacerba a iteração e a lógica da suplementação, do relato pelo testemunho e do testemunho pelo relato até o paroxismo: até a não-permanência do relato diante de si mesmo, em que a ficção é o próprio trabalho do distanciamento, aspecto tão caro à obra crítica de Blanchot. As palavras de Derrida, por não vertidas ao português, merecem talvez menção direta:

Tudo é relato [récit] e nada o é, a saída para fora do relato permanece no relato [récit] sob um modo não inclusivo e esta estrutura é tão pouco dialética que ela inscreve a dialética na elipse do relato [récit]. Tudo é relato [récit], nada o é, e a relação entre essas duas proposições, a estranha conjunção do relato [récit] ao sem-relato [non-récit], nós não saberemos se ela pertence à ordem do relato [récit]. ${ }^{124}$

E aí talvez resida a folia desta ficção, e a potência desse texto (e de Thomas l'obscur, e de Aminadab, e de tantos outros), de La folie du jour, esse relato que não faz senão começar. ${ }^{125}$

\footnotetext{
124 Idem, p. 274.

125 Ninguém melhor para justificá-lo do que o próprio Blanchot, que em um ensaio sobre Borges deixou registradas as seguintes palavras: "A errância, o fato de estar a caminho sem jamais poder deter-se, transformam o finito em infinito. A que se juntam esses traços singulares: do finito, que é no entanto fechado, pode-se sempre esperar sair, enquanto que a infinita vastidão é a prisão, não possuindo saída; assim como todo lugar absolutamente sem saída torna-se infinito. O lugar do extravio ignora a linha reta; não se vai jamais de um ponto a um outro; não se parte daqui para lá chegar; nenhum ponto de partida e nenhum começo para a caminhada. Antes de ter começado, já se recomeça; antes de ter realizado, se repete, e esse tipo de absurdo consiste em retornar sem jamais ter partido, ou em começar por recomeçar, é o segredo da 'má' eternidade, correspondendo ao 'mau' infinito, de que um e outro recebem talvez o sentido do devir." (BLANCHOT, 1999, p. 131)
} 


\section{Capítulo VI - Da questão do sentido em Blanchot}


“J'avais perdu le sens de l'histoire." - La folie du jour ${ }^{126}$

"Ne pas écrire, effet d'écriture" - L'Écriture du désastre ${ }^{127}$

Uma das figuras eleitas em Sein und Zeit para dar conta da existencialidade do Dasein, e precisamente no que diz respeito à "antecipação hermenêutica" do sentido no Dasein, como Heidegger diz no próprio livro e como nos relembra JeanLuc Nancy no texto que dedicou à questão do sentido imaginada por Heidegger, Le partage des voix, o círculo remete, sim, ao notório ir e vir entre texto e contexto que toda leitura pressupõe, em que a compreensão de um exige a compreensão antecipada do outro, assim como a compreensão do sentido exige certa antecipação do sentido, ou uma compreensão vaga do ser, como já dizia o mesmo Heidegger, mas a imagem do círculo remete também ao abismo contido nessa noção, abismo enxergado por Heidegger no hermeneuein grego, tanto em Sein und Zeit como em Unterwegs zur Sprache. Remetemo-nos à seguinte passagem do texto de Nancy:

\begin{abstract}
L'hermeneuein désigne cette antécédence constitutive, qui n'est ni celle d'une intention, ni celle d'une croyance, ni celle d'une participation au sens - mais qui est le sens. Le "sens" de l'hermeneuein tient dans cette avance du sens sur lui-même, une avance qu'on pourrait dire infinie si elle n'était la marque distinctive de la finitude de l'être-là. Et il se pourrait bien qu'il tienne aussi, de ce fait, dans un retard (infini/fini) du sens sur lui-même, dans une différance qu'il faudrait importer ici de I'interprétation" de Heidegger par Derrida. Antécédent-différant, l'hermeneuein ne nomme pas le contraire d'un "cercle herméneutique", mais tout autre chose: cela à quoi tout cercle herméneutique, qu'il le veuille ou non, se trouve, en tant que cercle, paradoxalement ouvert. C'est-à-dire à cette altérité ou à cette altération du sens, sans laquelle l'identification d'un sens - le retour au même du cercle ne pourrait même pas avoir lieu. ${ }^{128}$
\end{abstract}

Insuficiente, portanto, ceder à leitura da noção de círculo romântica ou historicista que Ihe conferia o status de mera antecipação e protensão do sentido; todo círculo, afinal, se encontra irremediável e "paradoxalmente" aberto, abertura do sentido sobre si mesmo que é o próprio sentido e que permite tanto a compreensão

\footnotetext{
126 "Eu havia perdido o sentido da história."

127 "Não escrever, efeito de escritura."

128 "O hermeneuein designa esta antecedência constitutiva, que não é nem aquela de uma intenção, nem aquela de uma crença, nem aquela de uma participação no sentido - mas que é o sentido. $O$ 'sentido' do hermeneuein detem-se neste avanço do sentido sobre ele mesmo, um avanço que poderia-se dizer infinito se ele não fosse a marca distintiva da finitude do Dasein. E poderia dizer-se que ele também se detém, por conta desse fato, em um retardamento (infinito/finito) do sentido sobre ele mesmo, em uma différance que seria necessário emprestar aqui da 'interpretação' de Heidegger por Derrida. Antecedente-diferente, o hermeneuein não nomeia o contrário de um 'círculo hermenêutico', mas coisa totalmente outra: aquilo por conta de que todo círculo hermenêutico, queira ou não, enquanto círculo, paradoxalmente aberto. Isto é, essa alteridade, ou essa alteração do sentido, sem a qual a identificação de um sentido - o retorno mesmo ao círculo - não poderia mesmo ter lugar." (NANCY, 1982, p. 39)
} 
de um sentido, isto é, a interrupção do movimento e da leitura, a cristalização e a sedimentação dos sentidos; e como a possibilidade da compreensão de um sentido, o movimento contínuo da mensagem, ou o "hermeneuein", o movimento indefinido da compreensão, que nunca cessa. São esses os dois sentidos, antagônicos segundo as leituras vulgares, da noção de sentido. O essencial do hermeneuein não é somente a antecipação, a participação anterior no sentido, a compreensão vaga do ser de que já se dispõe, necessária para a compreensão ou leitura do que quer que seja; o sentido anuncia-se no Dasein, mas não permite que ele subsista de maneira própria enquanto sujeito do ato de compreensão ou leitura. É a origem extra-arcaica do sentido, que faz com que não se possa dar uma origem ao sentido, ou a "origem infinita do círculo", no dizer de Nancy. Não somente desde sempre e já nos encontramos presos na teia do sentido e do arco do hermenêutico, toda leitura sendo já a leitura de uma leitura de uma leitura, e "para ler um livro é necessário havê-los lido todos", como dizia Jorge Luis Borges, mas também como disse Nancy, lidando com o sentido, problema constante de sua obra:

II ne suffit pas de dire que nous sommes toujours-déjà pris dans le cercle, si l'on entend par là que nous sommes toujours-déjà originés. C'est l'origine même (celle qu'est le sens autant que celle qu'est la bouche de l'interprète) qui est toujoursdéjà déprise d'elle-même, par l'ouverture et l'annonce selon lesquelles il y a du sens qui advient. - De manière analogue, là où l'herméneutique, ainsi qu'on l'a dit, implique que la participation au sens n'est jamais interrompue em profondeur, I'hermeneuein ne permet même pas d'envisager une telle implication. II n'y est question ni de discontinuité ni de continuité, mais d'un battement - éclipse et éclat tout ensemble, syncope de la partition du sens - où s'ouvre le sens. Une ouverture - au sens actif du terme - n'est ni interrompue, ni ininterrompue: elle ouvre, elle s'ouvre. ${ }^{129}$

O hermenêutico é apenas uma das facetas, portanto, do hermeneuein, e o círculo hermenêutico a outra, derivada da primeira. $O$ hermenêutico corresponde à dimensão antecipatória, e o hermeneuein à estrutura antecipatória ou 'anunciativa' do sentido. Não há, por outro lado, fim ou origem na outra dimensão do sentido. "le sens 'consiste' dans l'absence d'origine et de fin", nos diz Nancy. O sentido, mais do

\footnotetext{
129 "Não basta dizer que nós estamos sempre já presos no círculo, se poraí entendemos que somos desde já originados. E a origem mesma (tanto aquela que é o sentido quanto aquela que é a boca do intérprete) que é sempre já despojada dela mesma, pela abertura e o anúncio segundo os quais há sentido que advém. De maneira análoga, aí onde a hermenêutica, assim que a dizemos, implica que a participação no sentido jamais se interrompe em profundidade, o hermeneuein não permite mesmo visar uma tal implicação. Não é questão, aí, de descontinuidade ou de continuidade, mas de um golpe - eclipse e brilho juntos, síncope da partição do sentido - em que se abre o sentido. Uma abertura no sentido ativo do termo - não é interrompida nem interrompe: ela abre, ela se abre." (NANCY, 1982, p. 37)
} 
que garantir a origem e vinculação entre um sentido e outro, é o abismo que leva de um sentido a outro. Não à toa, a mise en abyme foi a figura pela qual se decidiu Blanchot em um de seus textos mais emblemáticos.

Nancy definiu o sentido como abertura, abertura que surge no momento antecipatório da compreensão (levando aqui em conta o intricado esquema de Sein und Zeit). A antecipação surge do recuo da origem e do fim, isto é, à impossibilidade de um retorno ao sentido perdido. Assim como o Dasein, que só pode vir e voltar a si distendendo-se entre seus fins que recuam, isto é, seu nascimento e sua morte. $O$ sentido consiste plenamente em sua abertura, e nela é exaurido, não sendo plausível ou possível a volta à origem ou à própria possibilidade da origem. A figura da antecipação, da pré-compreensão não se abre segundo a perspectiva circular de um retorno final ao sentido original, pleno, perdido e agora sublimado, compreendido. Não houve - assim como não há - nada perdido, nada passível de recuperação e, precisamente, nenhum sentido perdido de que tenhamos nos apartado e a que pudéssemos retornar. A perda, nos ditos "pensamentos do retorno", é o denominador comum, dado que todos pressupõem um sentido que se perdeu, mas cuja perda pode ser desfeita ou, ao menos, mitigada. A perda é também apenas um simulacro: um sentido perdido pode ser recuperado, recapturado do próprio movimento do sentido; a atenção se volta para o momento da perda do sentido, que é também a clausura do sentido, o momento em que o sentido se mostra enquanto abertura do sentido - e nada além disso. Um pensamento finito do sentido, um pensamento do sentido finito não busca a presentificação do sentido em suas sedimentações, seus substratos variados, na eterna busca de um testemunho fiel, coincidente com o fiat lux primeiro, mas compreender o modo como o sentido irrompe enquanto abertura, enquanto inscrição - ou "ex-crição", termo utilizado por Nancy - um movimento de expropriação constituinte do próprio movimento de apropriação de sentido. Nancy falou também da "abertura ínfima" do sentido, a dimensão de abertura da própria clausura. (essa figura habita, de formas muito distintas, os pensamentos de Heidegger, Derrida, Blanchot e Nancy). Esse excesso de sentido assombra todo e qualquer significado, assombra cada testemunho com a possibilidade do perjúrio, e - por que não - todo perjúrio, toda fábula, todo verso - com a possibilidade do testemunho. Essa perda possível, essa perda que tudo põe em estado de perda é a abertura impossível do 
sentido impossível, ou a declosão, a abertura residente no fundo da clausura, um sentido final de qualquer significação.

Esse aspecto de seu pensamento carrega consigo certa crítica da hermenêutica, mas também da fenomenologia. São ainda análises da sedimentação do sentido, de suas diferentes configurações, mas com uma diferença: para Nancy a própria ideia de uma interrupção do sentido - o que é a redução fenomenológica de Husserl, preconizada em seus primeiros ensaios como o método essencial para o conhecimento "das coisas mesmas", que pressupunha uma "epokhé" do sentido, uma suspensão do sentido que permitiria conhecer os atos intencionais constitutivos do sentido, antes da sua estabilização em sentidos e significações específicas esse é o projeto essencialmente impossível da fenomenologia, segundo Nancy, e um gesto que, embora necessário em outro momento, deve ser abandonado. Palavras de Nancy: "não pode haver epokhé do sentido, ou 'suspensão' de uma 'tese ingênua' do sentido, ou 'colocar em parênteses' do sentido. A epokhé ela mesma já foi tomada pelo sentido e pelo mundo. Que o sentido ele mesmo é infinitamente suspenso ou em suspense, que a suspensão é seu estado ou seu sentido mesmo não impede, antes impõe a condição de que não pode haver gesto possível de suspensão do sentido através do qual poder-se-ia ganhar acesso à origem do sentido, assim como a seu fim." (Nancy, 1997b, p. 19). Blanchot dissera coisa muito semelhante da redução fenomenológica - e da relação da empresa fenomenológica com a literatura, em um ensaio recolhido em L'Entretien Infini: “Não é somente a posição natural nem mesmo existencial que deveria ser suspensa para que, em sua luz desafetada, possa aparecer o sentido; é o sentido ele mesmo que não toma sentido senão se pondo entre parênteses, entre aspas, e isso por uma redução infinita, permanecendo finalmente fora de sentido, como um fantasma que o dia dissipa e que no entanto nunca falta, pois a falta é sua marca." (Blanchot, 2006, p. 448). Essa configuração assume então "outro gesto", esse coup de style que poderíamos dizer "disseminante" ou "disseminativo" ${ }^{130}$, exatamente no que ele tem

\footnotetext{
130 Já que mencionamos Derrida, a seguinte passagem de L'Écriture et la différance mostra a proximidade de seu pensamento com o de Nancy, ao menos nesse sentido em particular: " (...) Escrever é saber que isso que não está ainda produzido na letra não tem outra morada, não nos espera como prescrição em algum tómo oupávıos ou algum entendimento divino. O sentido deve esperar ser dito ou escrito para habitar-se a si mesmo e tornar isso que ao diferir de si ele é: o sentido. É isso que Husserl nos ensina a pensar na Origem da Geometria: $O$ ato literário reencontra assim sua fonte e seu verdadeiro poder. Em um fragmento do livro que ele projetava consagrar à Origem da Verdade, Merleau-Ponty escrevia: 'a comunicação em literatura não é o simples apelo do escritor à significações que fariam parte de um a priori do espírito humano: antes ela neles suscita
} 
de hiperbólico: ser idéia diametralmente oposta ao conceito de redução fenomenológica, seja uma redução impossível - no sentido de Nancy - seja uma redução infinita ou uma "redução da redução" - no sentido de Blanchot.

Uma das escolhas lexicais de Nancy, por sorte, pode ser vertida ao português sem grande prejuízo: "le sens s'entrouvre", "o sentido entreabre-se", dada a proporção entre a clausura e a abertura do sentido: tal qual a asa ou o leque - e nos remetemos aqui à leitura que Jean-Pierre Richard fez da obra de Mallarmé - o sentido, em seu duplo elo, abre-se à medida que fecha e fecha-se à medida que abre. A perda ou o ganho do sentido, ou sua clausura, portanto, no sentido que the deu Nancy, constitui a abertura mesma do sentido. A vontade de retornar ao sentido perdido, que segundo Nancy constitui o projeto mesmo da filosofia (e, como vimos, também o da fenomenologia que se ensaia ao longo de todo o século passado, e mesmo de grande parte da literatura de consumo geral), não é portanto senão uma tentativa de escapar à faceta radical do sentido, à exposição ao sentido, situação liminar de que a literatura é talvez a expressão inessencial. A tentativa de retorno, seja a um sentido anterior, mais nobre, puro, ou próximo da origem, seja a um âmbito anterior, ainda não esfacelado de dentro pelo próprio movimento do sentido, é uma tentativa, segundo Nancy, de escapar à finitude radical do sentido. É à extremidade do sentido que o filósofo quer dedicar seus pensamentos. Como diz Nancy em Le sens du monde:

(...) 'arte'é o simbólico ele mesmo no lugar e no instante de sua interrupção. É o segredo - prazer e/ou dor - que interrompe a simbolização do simbólico e desse modo entrega o 'plus-de-sens', o infinitamente 'plus-de-sens' através do qual a existência se relaciona e se expõe a si mesma. Essa relação não se fecha em um círculo de significação; ela suspende todos tais círculos, difrata e torna frágil o sentido significado. Ela expõe o sentido como segredo do que nada contém de oculto, nenhuma profundidade misteriosa ou mística, como o segredo do que nada compreende senão o múltiplo, discreto, descontínuo, heterogêneo, e singular toque do ser ele mesmo. - (NANCY, 1997b, p. 137)

Ao sentido compreendido enquanto significação - isto é, o sentido "em geral" - corresponde o sentido enquanto presentificação de um significado. A significação é dupla: diz respeito tanto ao estabelecimento de uma relação entre uma realidade sensível a uma realidade ideal; ou, de modo inverso, de uma realidade ideal a uma

pelo treinamento ou por um tipo de ação oblíqua. Junto ao escritor o pensamento não dirige a linguagem do fora: o escritor é ele mesmo como um novo idioma que se constrói". "Minhas palavras me surpreendem a mim mesmo e ensinam-me meu pensamento', dizia ele." (DERRIDA, 1967, p. 2122) 
realidade factual ou sensível. Essa sutura entre representante e representado é o que, segundo Nancy (e outros, como Derrida), determina que um aspecto do signo apresente o outro, fazendo com que a significação assuma ares de realização dialética da oposição primeva entre o âmbito do sensível e o do inteligível. Através do elo da significação, os conceitos se preenchem e a intuição vê. Nas palavras de Nancy, "A significação é então o verdadeiro modelo de uma estrutura ou sistema que é fechado sobre si mesmo, ou melhor ainda, como a clausura ela mesma. (itálico do autor)". Essa é a dimensão de clausura do sentido que mencionamos, ou a significação, que inspirou inadvertida e inexoravelmente tanta literatura, o que é nossa hipótese no presente ensaio. A ela corresponderia, talvez, a "linguagem ordinária" de que fala Blanchot em La littérature et le droit à la mort, aquela para a qual as palavras e as coisas correspondem pacificamente.

E a outra dimensão do sentido, já mencionada: a abertura. É o sentido entendido enquanto abertura abissal, o sentido enquanto "désoeuvrement", enquanto "undoing", enquanto "desfazimento", desobramento; distante da atividade representacional de um sujeito hipotético, ou como diz o Nancy: “(...) Experimentando uma 'entrada' na significação, o Ocidente experienciou uma saída de algo que ele não poderia significar, e consequentemente a impossibilidade de significar, seja seu próprio advento, seja o estabelecimento da ordem da significação." (Nancy, 1997a, p. 28) O sentido no limite da significação: e não somente uma nova interpretação do sistema da significação e de suas suturas, em que toda a realidade significada é desde já tomada por uma interpretação. Nancy então faz sua inversão, já em L'oubli de la philosophie, dizendo que o sentido não tem lugar na significação e muito menos através dela, mas que o sentido, e cito Nancy,

(...) o sentido - entendido como presentificação ou como vir à presença preexiste a significação e a excede. A verdade, essa verdade com a qual nós somos inevitavelmente confrontados e que nossa história nos apresenta, não é que o sentido tem lugar através da significação e por meio dela, mas que sentido, pelo contrário, é o elemento no qual podem haver significações, interpretações, representações. Não é a linguagem, não é o logos em geral, que faz o significado, mas o oposto. Sentido, nesse sentido, não é um sentido; não é uma significação, seja determinada ou indeterminada, completa ou ainda em progresso, já presente ou ainda a ser conquistada. Sentido é a possibilidade de significações; é o sistema de sua presentificação e o limite de seus sentidos."(...)“O sentido, enquanto aquilo que excede a significação, não tem lugar antes, debaixo, além ou depois da significação, mas em seu limite, ao qual a filosofia deve se expor. - (NANCY, 1997a, p. 59) 
"O sentido não tem talvez outro sentido senão o de uma abertura e désoeuvrement que se enclausura na significação", frase que poderia, em nossa opinião, resumir boa parte do que tanto se chamou de desconstrução. Citando novamente Nancy,

\begin{abstract}
$O$ fato de que o sentido nesse sentido infinitamente excede a significação, e que ele nem tem nem dá significação, não faz dele nem o não-sentido, nem o destino, nem nenhuma aborrecida necessidade. É feito de uma aposta constante, a de ser exposto; somos nós enquanto expostos, a um espaço e a nós mesmos enquanto espaço, a um tempo e a nós mesmos enquanto tempo, à linguagem, a nós mesmos, isto é, a nós outros, ao mal, ao bem, à escolha, à decisão, à escolhas e decisões, no evento de nossas significações. Através dessa exposição, que nos apresenta ao sentido e que nos apresenta o sentido, nós somos poupados de ser arrebatados na presença que resulta da significação. Pois enquanto ela mantém a presença à distância, a significação nos mantém diante dela, imóvel. Mas o sentido ofertado no limite da significação nos leva ao movimento de apresentação a...que é uma ruptura da presença ela mesma: não somente a ruptura das evidências, certezas, e garantias (pode haver também uma completa garantia no erigir do sentido), mas, mais profundamente, uma ruptura da significação e de sua ordem. (NANCY, 1997a, p. 63)
\end{abstract}

Tornar frágil, portanto, todo círculo da interpretação e da significação, e assinalando assim o 'sentido' enquanto 'exposição' à suspensão do sentido que é o próprio ser do sentido. Rompendo a um só tempo a continuidade do texto e da leitura - não à toa, a exposição à luz excessiva, a exposição ao sentido excessivo são um dos temas recorrentes de La folie du jour, Blanchot elege a figura, desenhada por Derrida em um de seus seminários ministrados na década de 1970, um círculo com duas aberturas: duplo elo que não permite que a leitura se estabilize, que não permite que se diferencie o relato do relatado, por um lado, preservando assim o sentido do sentido significado; e duplo elo que também torna necessário o reinício constante do relato, remetendo o seu quase-final ao seu quase-início, indefinidamente. Ao invés de um círculo - a que remetem tanto a mise en abyme como compreendida no mais das vezes, e seus círculos concêntricos, como o círculo hermenêutico, um círculo vazado de duas bocas, a do intérprete ou relatante e a própria abertura do sentido. O sentido aqui diz respeito à abertura dessa estranha figura sugerida por Blanchot no relato do que à clausura do círculo hermenêutico (significação).

Não se trata mais, portanto, da arte que representa a presentificação ou substanciação, epifania do ser, testemunho do ser, como Heidegger preconizava no ensaio sobre $A$ Origem da obra de arte; mas da arte-esvaziamento do ser, ausência de sentido a que só pode responder um outro texto, um outro sentido. Não existe 
mais a possibilidade do texto linear, relato teleológico do acontecimento inaudito e perene do ser. "Presentificação sem presença", nos diz Nancy em Le sens du monde. Ou como disse Levinas, sobre a experiência da literatura em Blanchot, “(...) l'écriture entend en finir et n'en finit pas d'en finir en dessinant le non-englobable espace littéraire". O mesmo Levinas se referiu à totalidade da obra ficcional de Blanchot como "la fable de la fermeture de l'être".

Dois sentidos, ao menos, da loucura do dia e do sentido: primeiramente a loucura do título, em que a disseminação do sentido é incessante; em segundo lugar a loucura do próprio récit, o maquinário da repetição que torna incessante também o récit, emulando de certa forma a disseminação do sentido contida no título "La folie du jour". Já o título anuncia - como de resto a maioria dos títulos dos livros de Blanchot - o infinito do sentido, o infinito deslocamento (Blanchot talvez dissesse deslizamento) do sentido. Pois são diversas as loucuras: a loucura do dia no sentido do dia presente, do dia de hoje, mas também a loucura de atualmente, da atualidade; a loucura da ordem do dia. Talvez, e principalmente, a loucura que o próprio dia pressupõe, a loucura de haver o dia, um dia. A loucura da abertura, da infinidade e infinitude do movimento do sentido. A loucura - sentido assinalado por Derrida em 'Titre - à préciser', em Parages - enquanto loucura da linguagem, loucura da disseminação de sentidos contida em uma simples palavra, que é em si uma pletora de significados e sentidos, a própria palavra dia, 'jour': luz, época, ser, existência, jornada, atualidade, tempo, aurora, crepúsculo, vida, vista, torsão, fenda, fissura, abertura. Loucura portanto da linguagem e do dia, loucura da inteligibilidade: loucura do récit, loucura do sentido. Blanchot certamente se dá conta do sentido militar-estratégico, antigo, da palavra 'jour', justamente o de abertura, fenda, ferida por onde pode passar a luz do dia. O dia-abertura assombra o verbete 'jour', sendo dele a ferida - ou "fissura ínfima", como diz Nancy, através da qual pode passar o sentido que subtrai o sentido do próprio relato.

E não é somente essa característica que fez com que Derrida se referisse à La folie du jour como 'récit du récit en déconstruction'; existem também os mecanismos descritos nos textos de Parages, a mise en abyme radicalizada, em duplo elo, que Derrida chamou de 'quiasma', em uma tentativa de descrição do modo como dentro do próprio texto a demanda pela narrativa é respondida por uma narrativa que só ao final descobrimos ser a narrativa que lemos, e assim por diante: uma mise en abyme, enfim, que não permite que discirnamos de modo definitivo o 
sentido do relato que temos em mãos, ou que simplesmente finalizemos sua leitura, sendo levados a reiniciá-la incessantemente. Um dia que não cessa: talvez não haja imagem mais adequada para expressar o sentido, tanto no sentido do sentido imaginado por Nancy como no sentido espectral imaginado por Blanchot. Que nos seja permitido repetir, a ficção de Blanchot é "(...) a fábula da clausura do ser", como dizia Levinas. De resto, a figura do sentido em Blanchot é também a imagem da morte: ou, melhor dizendo, da impossibilidade da morte, isto é, do fato de que não podemos cessar de ser, assim como não podemos deter de uma vez por todas o movimento suspensivo do sentido. Como diz Blanchot sobre o conto "O Caçador Gracus", de Franz Kafka:

II avait joyeusement accepté la vie et joyeusement accepté la fin de sa vie - une fois tué, il attendait sa mort dans la joie il était étendu et il attendait. "Alors, dit-il, arriva le malheur." Ce malheur, c'est l'impossibilité de la mort, c'est la dérision jetée sur les grands subterfuges humains, la nuit, le néant, le silence. II n'y a pas de fin, il n'y a pas de possibilité d'en finir avec le jour, avec le sens des choses, avec l'espoir : telle est la vérité dont l'homme d'Occident a fait un symbole de félicité, qu'il a cherché à rendre supportable en en dégageant la pente heureuse, celle de l'immortalité, d'une survivance qui compenserait la vie. Mais cette survivance,c'est notre vie même. - (BLANCHOT, 1949, p. 15) ${ }^{131}$

É a essa necessidade de um outro gesto, é a essa posição diante do sentido que corresponde, pensamos, um texto como La folie du jour, tanto do ponto de vista formal como do ponto de vista do conteúdo, se é que se pode discernir entre esses dois âmbitos no texto de Blanchot. O texto carrega consigo, a nosso ver, uma estrutura que merece ser analisada à luz opaca da obra de Nancy. Pois a literatura respondeu durante muito tempo, salvo algumas exceções, à clausura do sentido, ao sentido enquanto edificação de um mundo, enquanto presentificação, apoteose e testemunho do sentido da vida e das coisas, e faz-se necessário um texto que mostre o sentido enquanto antecâmara, enquanto vestíbulo, enquanto soleira (seuil), um texto que se detenha, que faça-nos deter-nos diante do sentido, um pouco aquém: um texto que corresponda ao pas au-delà de Blanchot. Um sentido definido

\footnotetext{
131 "Ele havia aceito alegremente a vida e alegremente aceito o fim de sua vida - uma vez morto, ele esperava sua morte na alegria com que era esperado e ele esperava. 'Então, disse ele, chegou a infelicidade' Essa infelicidade, é a impossibilidade da morte, é a derisão jogada sobre os grandes subterfúgios humanos, a noite, o nada, o silêncio. Não há mais fim, não há mais possibilidade de findar com o dia, com o sentido das coisas, com a esperança : tal é a verdade da qual o homem do Ocidente fez um símbolo de felicidade, que ele buscou tornar suportável dela retirando a inclinação feliz, a da imortalidade, de uma sobrevivência que compensaria a vida. Mas essa sobrevivência é nossa vida mesma."
} 
pela significação não pede nada além de um relato; já o sentido enquanto abertura pede uma certa estrutura textual, pede certo duplo elo, se podemos repetir essa expressão sem dela abusar. Como diz Derrida:

\begin{abstract}
(...) II n'en reste moins [...] que la double invagination, partout où elle se produit, a en elle-même une structure de récit en déconstruction. Le récit n'y est pas réductible. Avant même de 'concerner' un texte en forme de récit, la double invagination constitue le récit du récit, le récit de la déconstruction en déconstruction: le bord apparemment externe d'une clotûre, loin d'être simple, simplement externe et circulaire, selon la représentation philosophique de la philosophie, ne fait signe au-delà, vers le tout autre, qu'en se dédoublant, se faisant 'représenter', replier, re-marquer à l'intérieur de la clotûre, du moins dans ce que la structure produit comme effet d'intériorité. Mais c'est précisément cet effet de structure qui se déconstruit ici. (DERRIDA, 1986, p. 136) ${ }^{132}$
\end{abstract}

Nesse texto em especial - mas essa estrutura se repete, de uma forma ou de outra, em toda a literatura de Blanchot (Derrida estende, como é sabido, essa estrutura a qualquer texto possível) - Derrida enxergou um exemplo particularmente refinado do 'récit' da 'desconstrução em desconstrução', suplementariedade do texto que afeta todo texto, ficcional ou não, e a suplementariedade também da estrutura do próprio sentido. À clausura simples do texto, em que limites "superiores" e "inferiores" são determinados (podem ser determinados), em que o texto inaugura e encerra (enclausura) o intervalo em que acontece, Blanchot esboça o texto sem clausura, ou o texto que busca limitar a significação à clausura, dando vazão à segunda impossibilidade do sentido em Nancy (mais próximo, nesse sentido, de Blanchot): não se pode fazer cessar o sentido. O texto em que o sentido não se cristaliza em uma significação precisa, mas acontece enquanto envio, remetimento, enquanto chegada constante e infinda. Esse é o dia incessante de La folie du jour: o dia que não acaba é o dia do sentido, sentido esse que Nancy nos disse, em Le sens du monde, que é a maior das veleidades da fenomenologia supor que se pode interrompê-lo com fins analíticos, ou simplesmente suspender seu movimento a fim de melhor perscrutar sua constituição, pois o sentido do sentido é a suspensão do sentido, a interrupção, a epokhé husserliana. Não há saída do sentido, assim como

\footnotetext{
132 "Não é menos real que (...) a dupla invaginação, por toda parte onde se produz, tem nela mesma uma estrutura de récit em desconstrução. O récit não é a ela redutível. Antes mesmo de 'concernir' a um texto em forma de récit, a dupla invaginação constitui o récit do récit, o récit da desconstrução em desconstrução: a borda aparentemente externa de uma clausura, longe de ser simples, simplesmente externa e circular, segundo a representação filosófica da filosofia, não acena ao além, ao totalmente outro, senão em se desdobrando, se fazendo 'representar', redobrar, re-marcar no interior da clausura, ao menos no que a estrutura produz como efeito de interioridade. Mas é precisamente esse efeito de estrutura que se desconstrói aqui."
} 
não há fim no dia louco da loucura do dia, não há um fim do sentido (nos dois sentidos que o termo fim adquire no duplo genitivo) assim como não há um fim do dia. Não à toa, tanto Derrida quanto Nancy se referem à abertura, exemplificada pela boca, quando tratam da questão do sentido e da literatura: no texto que publicou recentemente em uma revista brasileira, “...devrait-il être un roman...", Nancy se refere à literatura como aquilo “(...) que nenhum dado precedeu, senão a abertura em si, que não é um dado, mas o dom em si - pois não se deve entendê-la como a abertura de um túnel, sólido e fixo, mas como a de uma boca, móvel à mercê de falas pelas quais se afeta, ou ainda como a de uma ópera, que se precipita para dar o tom, lançar o movimento, abrir as cortinas do pano" (Nancy, 2012, p. 258). A literatura, ou a escritura em sentido mais amplo, busca considerar não o relato do acontecimento - de modo análogo aquele segundo o qual Blanchot conceituava o récit em Le livre à venir - mas em relatar o que não teve lugar, em ex-crever o que não aconteceu de fato. Cito novamente o belo de Nancy: "Sua vinda abre o rastro do que é vir em geral: vir ao mundo, vir à luz, a vinda do dia em si". As passagens a seguir, retiradas de La part du feu, mostram um Nancy próximo de Blanchot, que num primeiro momento associa o sentido ao dia (mostrando que a escolha lexical de La folie du jour é uma constante em sua obra):

(...) Dieu avait créé les êtres, mais l'homme dut les anéantir. C'est alors qu'ils prirent un sens pour lui, et il les créa à son tour à partir de cette mort où ils avaient disparu; seulement, au lieu des êtres et, comme on dit, des existants, il n'y eut plus que de l'être, et l'homme fut condamné à ne pouvoir rien approcher et rien vivre que par le sens qu'il lui fallait faire naître. Il se vit enfermé dans le jour, et il sut que ce jour ne voulait pas finir, car la fin elle-même était lumière, puisque c'est de la fin des êtres qu'était venue leur signification, qui est l'être - (BLANCHOT, 1949, p. $312-313)^{133}$

En niant le jour, la littérature reconstruit le jour comme fatalité; en affirmant la nuit, elle trouve la nuit comme l'impossibilité de la nuit. C'est là sa découverte. Quand il est lumière du monde, le jour nous rend clair ce qu'il nous donne à voir, il est pouvoir de saisir, de vivre, réponse "comprise" dans chaque question. Mais si nous demandons compte du jour, si nous en venons à le repousser pour savoir ce qu'il y a avant le jour, sous le jour, alors nous dévouvrons qu'il est déjà présent, et ce qu'il y a avant le jour, c'est le jour encore, mais comme impuissance à disparaître et non comme pouvoir de faire apparaître, obscure nécessité et non liberté éclairante. La nature donc de ce qu'il y a avant le jour, de l'existence prédiurne, c'est la face obscure du jour, et cette face obscure n'est pas le mystère non dévoilé de son commencement, c'est sa présence inévitable, un "Il n'y a pas de jour" qui se

\footnotetext{
133 “(...) Deus havia criado os seres, mas o homem deve os aniquilar. Foi então que eles ganharam um sentido para ele, e ele os criou por sua vez a partir desta morte em que eles tinham desaparecido; só que agora, no lugar de seres e, como se diz, de existentes, não havia mais nada senão o ser, e o homem foi condenado a não poder se aproximar de nada e nada viver senão pelo sentido que the era necessário fazer nascer. Ele se viu encerrado no dia, e ele soube que esse dia não queria findar, pois o fim mesmo era luz, porque é do fim dos seres que era vinda sua significação, que é o ser"
} 
confond avec un "ll y a déjà du jour", son apparition coïncidant avec le moment où il n'est pas encore apparu. Le jour, dans le cours du jour, nous permet d'échapper aux choses, il nous les fait comprendre et, en nous les faisant comprendre, il les rend transparentes et comme nulles, - mais le jour est ce à quoi on n'échappe pas: en lui nous sommes libres, mais lui-même est fatalité, et le jour comme fatalité est l'être de ce qu'il y a avant le jour, l'existence dont il faut se détourner pour parler et pour comprendre.- (BLANCHOT, 1949, p. 318) ${ }^{134}$

Texto que não se finda, texto cuja repetição infinita suspende também o final do dia, e com ele sua loucura; texto que assim remete à loucura desse dia que nunca acaba, ao incessante da suspensão do sentido. Não há saída do sentido. Não há saída do mundo, não há saída desse sentido que é suspensão do sentido. O dia interminável. A abertura do sentido, em La folie du jour, a abertura do nexo da visibilidade é ela mesma somente abertura, e parte da "loucura do dia" retratada. Do círculo hermenêutico ao quiasma: da noção de sentido enquanto excesso à noção de sentido enquanto abertura, enquanto movimento incessante, impossibilidade de fim, "déclosion", não-clausura do sentido. A escrita, aqui, é a da falha do círculo, do círculo que fecha e não se fecha sobre si próprio: é Derrida lendo Edmond Jabès em Ellipse, de L'Écriture et la Différence, ou na belíssima leitura de Nancy em La Pensée Finie: o limite, na curiosa geometria das imagens fenomenológicas do texto e do excesso do sentido, "(...) é esse limite que a paixão demanda, que ela deseja. O limite do que, de modo a ser si mesmo e estar presente a si mesmo, não retorna a si mesmo. O círculo que ao mesmo tempo fecha a si mesmo e falha em fazê-lo: uma elipse." (NANCY, 2003, p. 95) Do círculo hermenêutico à elipse, da completude do sentido e a busca de um sentido original à incompletude da mise en abyme, da elipse, do livro aberto que não se torna a fechar, é esse o caminho, a nosso ver, percorrido pelas figurações do texto na filosofia e literatura recentes.

\footnotetext{
134 "Negando o dia, a literatura reconstrói o dia como fatalidade; afirmando a noite, ela encontra a noite como impossibilidade da noite. É essa sua descoberta. Quando ele é luz do mundo, o dia nos torna claro isso que ele nos dá a ver, ele é poder de apreender, de viver, resposta 'compreendida' em cada questão. Mas se nós pedimos contas ao dia, se nós viemos a fazê-lo recuar para saber o que há antes do dia, sob o dia, então descobrimos que ele está já presente, e isso que há antes do dia, é o dia ainda, mas como impotência de desaparecer e não como poder de fazer aparecer, obscura necessidade e não liberdade esclarecedora. A natura do que há portanto antes do dia, da existência pré-diurna, é a face obscura do dia, e essa face obscura não é o mistério não desvelado de seu começo, é sua presença inevitável, um 'não há dia' que se confunde já com um 'há dia', sua aparição coincidindo com o momento em que ele ainda não apareceu. O dia, no curso do dia, nos permite escapar às coisas, ele nos faz compreendê-las, e nos fazendo compreendê-las, ele as torna transparentes e como que nular - mas o dia é isso do que não se escapa: nele somos livres, mas ele mesmo é fatalidade, e o dia como fatalidade é o ser disso que há antes do dia, a existência da qual é necessário se desviar para falar e para compreender."
} 
Considerações Finais 
Gostaria de iniciar esta conclusão, que pretendo breve, com um mea culpa: como disse Jean Starobinski no ensaio já clássico sobre Thomas l’Obscur, "Blanchot, na verdade, se oferece a uma compreensão interminável, não a uma explicação." Dada a dificuldade desse discurso ficcional, e dada a dificuldade na formulação de um discurso que lhe faça jus, tentei circunscrever parte do registro narrativo da obra de Blanchot, em um recorte que, como foi lembrado por um dos membros da banca de qualificação, tem algo de artificial no que diz respeito à cronologia, e de que gostaria de explicitar agora as suas razões. Os três textos com que lidei diretamente são da década de 1940, ou ao menos parcela significativa deles: Thomas l'Obscur, de 1941, e que em 1950 recebeu nova versão; Aminadab, de 1942; e La folie du jour, que surge em primeira versão em 1949. Há alguns traços comuns entre esses textos, ou ao menos um esforço que subjaz a todos, como tentei esclarecer no trabalho e como vou tentar deixar mais claro aqui, atendendo às críticas da banca de qualificação.

Em Thomas l'Obscur, livro que Blanchot reescreveu durante cerca de vinte anos, se dermos crédito a seu biógrafo, temos já a estrutura em aberto de um livro que não termina; ou, como disse Jean Starobinski, o primeiro, que eu saiba, a assinalar essa estrutura nas ficções de Blanchot, "O romance, em seu percurso completo, é a imagem amplificada de um circuito desenhado no primeiro capítulo. $O$ primeiro círculo, com seu ponto de chegada que quase coincide com o ponto de partida, é o modelo de um círculo maior, ao mesmo tempo análoga e diferente, que se fecha por sua vez retornando quase ao mesmo ponto". Essa estrutura diz respeito ao modo, e essa é uma das teses subsidiárias do presente trabalho, como Blanchot orquestra, a nosso ver, uma certa cena da exposição ao sentido, que toma algumas formas distintas; no caso de Thomas l'Obscur, o livro se inicia e termina com Thomas mergulhando no mar. Seria interessante talvez lembrar o que Derrida diz a respeito dessa cena e à analogia entre o título do livro, Thomas l'Obscur, que é um anagrama, quase, de Maurice Blanchot: que o nome de "M(eau)rice Blanch(eau)" é um nome entre duas águas, nome isolado, por assim dizer, em meio ao elemento aquoso, incerto do sentido; Thomas cercado pelo mar, portanto, ou o escritor cercado pelo fora desse sentido que o assombra e excede. A paisagem marinha, quero crer, é ontologicamente uma paisagem de extravio (como buscamos demonstrar também demonstrar também no seminário do grupo Escritura: Linguagem e Pensamento em setembro do presente ano), e a cena do seu encontro, 
uma cena abismal, tanto nas transformações pelas quais Thomas passa nas duas vezes em que entra no mar, mas que de certa forma se repete também quando ele se depara com o livro, no capítulo sobre a leitura. Um abismo, portanto, do sentido, seja esse figurado na paisagem marinha ou na paisagem do livro, ambas situações em que Thomas é engolido pela abertura do sentido: “(...) ele percebeu toda a estranheza que havia em ser observado por uma palavra como por um ser vivo, e não somente pela palavra, mas por todas as palavras que se encontravam nessa palavra, por todas aquelas que a acompanhavam e que por sua vez continham nelas mesmas outras palavras, como uma sequência de anjos se abrindo ao infinito até $o$ olho do absoluto." Aqui já temos também um primeiro emprego do que nomeamos talvez de modo precipitado de transfiguração da mise en abyme que é sintomático dessa tentativa, nessa mesma cena: na versão de 1941, inclusive, há a citação do texto que Thomas lê, entre aspas. Por fim, já temos aqui também a leitura que Blanchot retomaria em diversas obras do mito órfico, do mito da origem do canto, em que a obra de arte é de tal modo excessiva que somente pelo desvio se pode atingíla. Do ponto de vista da presença dessas cenas, inclusive, as duas obras são semelhantes: todas são mantidas na passagem da versão de 1941 pra de 1950.

Já em Aminadab, publicado em 1942, temos uma vez mais o mesmo personagem, Thomas, em uma cena diferente, mas que, quero crer, enfatiza 0 mesmo encontro de Thomas com o espaço da narrativa ou do sentido, quando ele, atraído mais uma vez ao fora por uma mulher, mas um fora, por assim dizer, que o personagem acessa entrando na casa, entrando nessa casa em que erra de cômodo a cômodo, buscando compreender o sentido implícito ou anterior, o sentido que rege as leis da casa, mas nunca acessando de fato a verticalidade ou presença do sentido, por mais que busque incessantemente esse sentido na sua interlocução com os demais inquilinos da casa. Essa casa, a meu ver, é outra imagem, outra cena do sentido e da relação da escritura com esse sentido. Como Alain Milon assinalou em ensaio recente, mesmo a composição da frase, em Blanchot, apresenta essa conformação de passagem, de jornada, como se a única coisa que a linguagem permitisse fosse essa jornada de um vocábulo a outro, ou, na analogia que imagino plausível, e que é outra das teses subsidiárias do meu trabalho, de um cômodo a outro, de uma palavra a outra, sem nunca acessar a plenitude do sentido. Aminadab é também o livro, lembre-se, que fez Sartre acusar Blanchot de meramente repetir o motivo do não sentido, mas a cena é muito mais complexa, a 
nosso ver; Na cena, por exemplo, em que os locatários, em um acesso de loucura, buscam subir aos andares de cima da casa de Aminadab, e atravessam o que Blanchot chama de "linha ideal", o que eles encontram é também o extravio, isto é, quando buscam nessa passagem de um cômodo a um cômodo superior a presença anterior do sentido, se deparam com a loucura e a morte. O livro é, da mesma forma, repleto de episódios en abyme, se podemos chamá-los assim, e mesmo a cena inteira pode ser vista como uma mise en abyme, a meu ver, como buscamos demonstrar no texto. Há em Aminadab, igualmente, a mesma leitura do mito órfico, afinal de contas Thomas entra na casa por conta do aceno de uma mulher, mulher que ao final do livro ele encontra e que the diz que não fora ele o esperado, e que, embora houvesse uma mensagem a ser entregue, embora alguém tenha sido o destinatário daquele aceno, não era ele, e portanto não havia propósito na sua busca pelo sentido, ou ao menos que esse sentido só pode ser atingido pelo desvio do olhar de Orfeu, que não pode encarar a obra de arte ou o sentido face a face sem fazer com que desvaneça. Por fim, temos a mesma exigência de interminabilidade; se em Thomas l'Obscur no final do livro somos informados da vergonha que Thomas sente só de pensar poder finalizar a experiência abissal do sentido, em encontrar um fim para o movimento abissal do sentido, em Aminadab Thomas é simplesmente engolido pela noite.

Já em La folie du jour, de 1949, e que recebeu, como é do feitio de Blanchot, outro título na versão publicada em 1973, temos - e essa é também uma das teses subsidiárias do presente trabalho - uma condensação da narrativa, do récit, e não mais temos simplesmente uma imagem da infinitude do sentido e de suas transformações, como eram o mar, a floresta, o livro, em Thomas l'obscur, ou como os cômodos mal iluminados de Aminadab, mas um outro dispositivo, que envolve dessa vez uma radicalização, e essa é, por assim dizer, a terceira tese subsidiária que buscamos tatear no presente texto, da mise en abyme. Blanchot buscou, com La folie du jour, infinitizar a experiência do sentido através do próprio texto: pela radicalização dessa estrutura já presente em outros textos, como quando, por exemplo, Thomas lê um livro semelhante a Thomas l'Obscur em Thomas l'Obscur, ou quando Thomas examina um quadro, em Aminadab, que retrata o espaço no qual ele se vê naquele exato instante, com a exceção, talvez, de um detalhe, em La folie du jour a questão da interminabilidade do texto e da experiência abismal do sentido torna-se parte da própria estrutura em abismo do texto, texto esse que, a rigor, como 
disse Derrida em Parages, é assombrado por um "inacabamento essencial"; é a estrutura complexa que Derrida chamou de "dupla invaginação quiasmática": o narrador, quando indagado pelas figuras do oftalmologista e do psiquiatra, quando solicitado que dê conta, como um homem de letras, do que "se passou de fato", au juste, responde com as palavras que nós, leitores, encontramos no início do texto: “Não sou nem sábio nem ignorante. Conheci alegrias (...)", isto é, essa espécie de mise en abyme transfigurada até o ponto de perder o que Lucien Dällenbach chamou de sua dimensão "explicativa" faz com que o texto, além de não terminar de fato, dado que somos enviados novamente ao seu início, seja ele mesmo atacado estruturalmente por esse inacabamento: loucura do dia, loucura do duplo genitivo do título, como lembrou o mesmo Derrida, de quem não pretendemos de modo algum esgotar a leitura; loucura da simultaneidade do sentido e de sua suspensão, loucura do dia prometido pelo sentido e pela linguagem.

Em suma, nosso propósito, e a tese propriamente dita do trabalho, é a existência de uma passagem, de Thomas l'Obscur a Aminadab, de um primeiro encontro com o elemento abissal da linguagem e do sentido, em que há ainda um sentido residual, constituído nas próprias cenas imaginadas por Blanchot, à exploração da mise en abyme em La folie du jour, texto que traz para o âmbito do próprio texto a infinitude do sentido, rompendo o liame entre o texto e o testemunho, entre a ficção e o testemunho, tornando porosas, por assim dizer, as suas bordas, as suas margens.

Desde o princípio, quando fora imaginada por Heidegger como o excesso do sentido em relação ao mundo, formulado ora como o própria possibilidade de postular esse mundo, ora como a antecedência desse mundo em relação à esfera da experiência, em que precisamente porque era capaz de constituir um mundo que o Dasein (essa experiência recebeu outros nomes no itinerário de seu pensamento) não podia simplesmente esquecer que estava presente em um mundo, com seus sentidos, sua linguagem, seu excesso e projeção, até a literatura que surge dessa concepção na França do pós-guerra, da qual um exemplo talvez privilegiado é a escritura ficcional e ensaística de Blanchot, devotada à cunhagem de uma ontologia do literário que está entre as coisas mais abissais propostas no domínio da língua francesa, tanto em termos estilísticos quanto em sua complexa ontologia e leitura, a questão do sentido é a questão incandescente do ocidente, como fizemos questão de relembrar na pena de Jean-Luc Nancy. Por isso nos dedicamos à genealogia de 
um dos formatos que essa questão adquire, que é a literatura de Blanchot, aqui representada em alguns trabalhos da década de 40, limitada a algumas obras, dada a própria dificuldade do objeto.

Jacques Derrida disse, na sua Introdução à Origem da Geometria de Husserl, que os projetos de Edmund Husserl e de James Joyce eram siameses em seu antagonismo: enquanto um imaginava tornar a linguagem tão transparente e unívoca quanto possível, e portanto capaz de preservar a memória e a história com a maior clareza possível, eliminando os efeitos da ambiguidade, através da redução fenomenológica e outros procedimentos, o outro buscava aumentar ao grau máximo a potência semântica da linguagem, condensando a linguagem ao máximo, até o ponto em que nenhum significado seja realmente capaz de aderir de fato ao significante, tornando assim toda linguagem tão equívoca quanto possível. Imaginamos que Derrida gostaria de ter-se imaginado entre essas duas posturas, talvez pendendo para a segunda; e gostaríamos de imaginar Maurice Blanchot, figura furtiva por excelência, como que situado precisamente entre esses dois esforços: na busca de uma literatura configurada precisamente entre a ausência completa de significado e a sua presença absoluta, como se o sentido somente pudesse soerguer da ruína do sentido, precisamente no momento em que a linguagem não se limita a ser unívoca ou equívoca, a significar o mínimo ou o máximo, suspensa nesse instante neutro, entre o sentido e sua ausência. Não sabemos, não podemos sabê-lo, se Blanchot concordaria com as palavras aqui escritas; é nosso modo de percebê-lo. Há, como dissemos, muitos modos de contar a história da questão do sentido e da linguagem na filosofia e na literatura, e nos ativemos à que consideramos possível e razoável com nossos recursos no momento. 


\section{Referências Bibliográficas}

AGAMBEN, Giorgio. A linguagem e a morte. Um seminário sobre o lugar da negatividade. Belo Horizonte: EdUFMG, 2006.

ALLEN, William S. Dead transcendence: Blanchot, Heidegger, and the reverse of language. In: Research in phenomenology, Nr. 29, 2009, p. 69.

ALLEN, William S. Ellipsis. On Heidegger, Hölderlin and Blanchot. New York: SUNY Press, 2008.

ALLEN, William S. The image of the absolute novel: Blanchot, Mallarmé, and Aminadab. In: MLN 125. Baltimore: The Johns Hopkins University Press, 2011.

ALLEN, William S. Repulsive image: the idea of literature after Blanchot. In: The Journal of the British Society for Phenomenology, Vol. 42, 2001.

ALLIEZ, Éric. Da impossibilidade da fenomenologia. São Paulo: Editora 34, 1996.

ANTONIOLI, Manola. Écriture de Maurice Blanchot. Fiction et théorie. Paris: Kimé, 1999.

ALMEIDA FILHO, Éclair Antonio. Do roman ao récit? Metamorfose e escritura do desastre em Thomas l'obscur, de Maurice Blanchot. In: Cadernos do IL, Nr. 39, 2009.

BATAILLE, Georges. La littérature et le mal. Paris: Gallimard, 2004.

BIDENT, Christophe. Maurice Blanchot, partenaire invisible. Seyssel: Champ Vallon, 2001.

BIDENT, Christophe e VILLAR, Pierre, eds. Maurice Blanchot, récits critiques. Paris:

Farrago, 2003.

BLANCHOT, Maurice. Aminadab. Paris: Gallimard, 1972.

BLANCHOT, Maurice. L'Amitié. Paris: Gallimard, 2004a.

BLANCHOT, Maurice. L'arrêt de mort. Paris: Gallimard, 2012.

BLANCHOT, Maurice. L'attente l'oubli. Edição eletrônica.

BLANCHOT, Maurice. Au moment voulu. Paris: Gallimard, 1951.

BLANCHOT, Maurice. Celui qui ne m’accompaignait pas. Paris: Gallimard, 1953.

BLANCHOT, Maurice. La communauté inavouable. Paris: Minuit, 1983.

BLANCHOT, Maurice. Depois do golpe. O ir-e-vir eterno. São Paulo: Lumme, 2012.

BLANCHOT, Maurice. Le dernier homme. Paris: Gallimard, 2001.

BLANCHT, Maurice. L'Écriture du désastre. Paris: Gallimard, 1980.

BLANCHOT, Maurice. L'Entretien Infini. Paris: Gallimard, 1969. 
BLANCHOT, Maurice. L'Espace littéraire. Paris: Gallimard, 1962.

BLANCHOT, Maurice. Le livre à venir. Paris: Gallimard, 1999.

BLANCHOT, Maurice. Faux pas. Paris: Gallimard, 2004b.

BLANCHOT, Maurice. La folie du jour. Paris: Gallimard, 2006.

BLANCHOT, Maurice. L'instant de ma mort. Paris: Gallimard, 2006.

BLANCHOT, Maurice. O livro por vir. São Paulo: Martins Fontes, 2005.

BLANCHOT, Maurice. La part du feu. Paris: Gallimard, 1984.

BLANCHOT, Maurice. Le pas au-delà. Paris: Gallimard, 1973.

BLANCHOT, Maurice. Thomas l'obscur. Roman. Paris: Gallimard, 2005.

BLANCHOT, Maurice. Thomas l'obscur. Nouvelle version. Paris: Gallimard, 2007.

BLANCHOT, Maurice. Le très-haut. Paris: Gallimard, 1947.

BRUNS, Gerald L. Maurice Blanchot - the refusal of philosophy. Baltimore: The Johns Hopkins University Press, 2005.

BUCLIN, Hadrien. Maurice Blanchot ou l'autonomie littéraire. Lausanne: Antipodes, 2011.

CARDOSO, Daniel B. Entre Heidegger e Blanchot: fenomenologia e literatura. Dissertação de mestrado. UnB, 2009.

CARDOSO, Daniel B. A loucura do dia. Tradução livre, 2009.

CLARK, Timothy. Derrida, Heidegger, Blanchot: sources of Derrida's notion and practice of literature. Cambridge: Cambridge University Press, 2010.

COLLIN, Françoise. Maurice Blanchot et la question de l'écriture. Paris: Gallimard, 1986.

COURTINE, Jean-François. La cause de la phénoménologie. Paris: P.U.F., 2007.

CROWELL, Steven. Husserl, Heidegger and the space of meaning: paths towards transcendental phenomenology. Evanston: Northwestern University Press, 2002.

DÄLLENBACH, Lucien. Le récit speculaire. Essai sur la mise en abyme. Paris: Seuil, 1977.

DECOUT, Maxime. Maurice Blanchot: une phénoménologie du récit. In: Cahiers de Narratologie, Nr. 22, 2012.

DEL LUNGO, Andrea. Maurice Blanchot: la folie du commencement. In: Studi di letteratura francese, Vol. XXII, 1997.

DERRIDA, Jacques. Acts of literature. London: Routledge, 1992.

DERRIDA, Jacques. Dissemination. London: The Athlon Press, 1981.

DERRIDA, Jacques. A escritura e a diferença. São Paulo: Perspectiva, 2002. 
DERRIDA, Jacques. Gramatologia. São Paulo: Perspectiva, 2002.

DERRIDA, Jacques e BLANCHOT, Maurice. The instant of my death. Demeure. Stanford: Stanford University Press, 1998.

DERRIDA, Jacques. Limited Inc. São Paulo: Papirus, 1991.

DERRIDA, Jacques. Marges: de la philosophie. Paris: Minuit, 1967.

DERRIDA, Jacques. On touching - Jean-Luc Nancy. Stanford: Stanford University Press, 2005.

DERRIDA, Jacques. Parages. Paris: Galilée, 1986.

DERRIDA, Jacques. La voix et le phénomène. Paris: P.U.F., 2010.

DE MAN, Paul. Impersonality in the criticism of Maurice Blanchot. In: Blindness and insight. Minneapolis: University of Minnesota Press, 1983.

DOWD, Garin V. "Glisser dans le vide", Blanchot, Thomas l'obscur and the space of literature. In: Angelaki: Journal of Theoretical Humanities, Nr. 4:3, 1999.

ELLISON, David R. Narrative and music in Kafka and Blanchot: the "singing" of Josephine. In: Yale French Studies, Nr. 93, 1998.

EYBEN, Piero (org.). Demoras na aporia: bordas do pensamento e da literatura. Vinhedo: Horizonte, 2012.

EYBEN, Piero (org.). Pensamento intruso: Jean-Luc Nancy \& Jacques Derrida. Vinhedo: Horizonte, 2014.

FITCH, Brian. Lire les récits de Maurice Blanchot. Amsterdam: Rodopi, 1992.

FOUCAULT, Michel. Ditos e Escritos III. Estética: Literatura e Pintura, Música e Cinema. Rio de Janeiro: Forense Universitária, 2001.

FREY, Hans J. e ALBERT, Georgia. The last man and the reader. In: Yale French Studies, The place of Maurice Blanchot, Nr. 93, 1998.

FRICHOT, Hélène. Nathalie's Rotunda: breaching the threshold of Maurice Blanchot's L'arrêt de mort. In: Colloquy Text Theory Critique, Nr. 10, 2005.

FRIÈS, Phillipe. La théorie fictive de Maurice Blanchot. Paris: L'Harmattan, 1999.

GENETTE, Gérard. O discurso da narrativa. Ensaio de método. Lisboa: Editorial Minerva, 1979.

GEROULANOS, Stefanos. Transparency thinking freedom (Maurice Blanchot's The most high). In: MLN, Nr. 122, 2007.

GILL, Carolyn B. Maurice Blanchot: the demand of writing. London: Routledge, 1996. GILONNE, Yves. La rhétorique du sublime dans l'oeuvre de Maurice Blanchot. Paris: L'Harmattan, 2008. 
GRAMONT, Jerôme. Blanchot et la phénoménologie: l'éffacement, l'événement. Paris: Corlevour, 2011.

GREGG, John. Maurice Blanchot and the literature of transgression. Princeton: Princeton University Press, 1994.

GUIGNON, Charles B. Heidegger and the problem of knowledge. Indiana: Hackett, 1983.

HAASE, Ulrich e LARGE, William. Maurice Blanchot. London: Routledge, 2001.

HAGELSTEIN, Maud. Maurice Blanchot: la genèse phénoménologique du concept de neutre. Texto eletrônico.

HARLINGUE, Olivier. Sans condition: Blanchot, la littérature, la philosophie. Paris: L'Harmattan, 2009.

HART, Kevin. Clandestine encounters: philosophy in the narrative of Maurice Blanchot. Notre Dame: Notre Dame University Press, 2010.

HART, Kevin e HARTMAN, Geoffrey H. (orgs.). The power of contestation: perspectives on Maurice Blanchot. Baltimore: Johns Hopkins University Press, 2004. HARTMAN, Geoffrey H. The fulness and nothingness of literature. In: Yale French Studies, Nr. 16, 1955-1956.

HEIDEGGER, Martin. A caminho da linguagem. Petrópolis: Vozes, 2003.

HEIDEGGER, Martin. Caminhos de Floresta. Lisboa: Calouste Gulbenkian, 2002. HEIDEGGER, Martin. Carta sobre o humanismo. Lisboa: Edições 70, 1992.

HEIDEGGER, Martin. History of the concept of time: Prolegomena. Bloomington: Indiana University Press, 1992.

HEIDEGGER, Martin. Kant and the problem of metaphysics. Bloomington: Indiana University Press, 1962.

HEIDEGGER, Martin. Lógica: a pergunta pela essência da linguagem. Lisboa:

Fundação Calouste Gulbenkian, 2008.

HEIDEGGER, Martin. Ontology - the hermeneutics of facticity. Bloomington: Indiana University Press, 2008.

HEIDEGGER, Martin. A origem da obra de arte. Lisboa: Edições 70, 2005.

HEIDEGGER, Martin. Phenomenology of intuition and expression. London:

Continuum, 2010.

HEIDEGGER, Martin. Ser e tempo. Petrópolis: Vozes, 2012.

HEIDEGGER, Martin. Towards the definition of philosophy. London: Continuum, 2008. 
HEWSON, Mark. Maurice Blanchot and literary criticism. London: Continuum, 2011. HILL, Leslie. Maurice Blanchot: Extreme contemporary. London: Routledge, 1997. HOLLAND, Michael. The Blanchot reader. Cambridge: Blackwell, 1995. HURAULT, Marie-Laure. Maurice Blanchot, le principe de fiction. Vincennes: PUV, 2000.

HUSSERL, Edmund. Investigações Lógicas: sexta investigação: elementos de uma elucidação fenomenológica do conhecimento. São Paulo: Abril Cultural, 1980. IYER, Lars. Blanchot's Communism. Art, philosophy and the political. New York: Palgrave Macmillan, 2004.

KISIEL, Theodore. SHEEHAN, Thomas. Becoming Heidegger: on the trail of his early occasional writings, 1910-1927. Evanston: Northwestern University Press, 2007. KOCKELMANS, Joseph J. On Heidegger and language. Evanston: Northwestern University Press, 1972.

LAFONT, Cristina. Heidegger, language, and world-disclosure. Cambridge:

Cambridge University Press, 2000.

LEVINAS, Emmanuel. Reality and its shadow. In: The Levinas reader.

LEVINAS, Emmanuel. The servant and her master. In: The Levinas reader.

LEVINAS, Emmanuel. Sobre Maurice Blanchot. Madrid: Editorial Trotta, 2000.

LEVINAS, Emmanuel. Totalidade e infinito. Lisboa: Edições 70, 2008.

LONDYN, Evelyne. Maurice Blanchot romancier. Paris : Nizet, 1976.

MACDOWELL, João A. A gênese da ontologia fundamental de Martin Heidegger. Ensaio de caracterização do modo de pensar de Sein und Zeit. São Paulo: Editora Herder, 1970.

MAJOREL, Jérémie. Portraits avec visage absent: Aminadab (1942) de Maurice Blanchot. In: Aléa, Vol. 12, Nr. 1.

MARION, Jean-Luc. Réduction et donation. Recherches sur Husserl Heidegger et la phénoménologie. Paris : PUF, 1989.

MASSIE, Pascal. The secret and the neuter: on Heidegger and Blanchot. In:

Research in Phenomenology, Nr. 37, 2007.

MERLEAU-PONTY, Maurice. A prosa do mundo. São Paulo: Cosac \& Naify, 2002. MICHAUD, Ginette. Literature in secret: crossing Derrida and Blanchot. In: Angelaki. Journal of theoretical humanities. Vol. 7, Nr. 2, 2002.

MIRAUX, Jean-Philippe. Maurice Blanchot: quiétude et inquiétude de la littérature. Paris: Éditions Nathan, 2005. 
MOLE, Gary D. Levinas, Blanchot, Jabès: Figures of estrangement. Miami: University Press of Florida, 1997.

Revue Critique. Nr. 229. Paris: Éditions de Minuit, 1966.

NANCY, Jean-Luc. L'adoration. Paris: Galilée, 2010.

NANCY, Jean-Luc. La communauté désoeuvrée. Paris: Christian Bourgois éditeur, 1999.

NANCY, Jean-Luc. La déclosion. Paris: Galilée, 2005.

NANCY, Jean-Luc. Le poids d'une pensée. Montréal-Grenoble: Le Griffon d'ArgilePresses Universitaires de Grenoble, 1991.

NANCY, Jean-Luc. Le sens du monde. Paris: Galilée, 1993.

NASCIMENTO, Evando. Derrida e a literatura. "Notas" de literatura e filosofia nos textos da desconstrução. Niterói: EdUFF, 1999.

NUNES, Benedito. Hermenêutica e Poesia: O pensamento poético. Belo Horizonte: EdUFMG, 1999.

PAULHAN, Jean. Les fleurs de tarbes ou la terreur dans les lettres. Paris : Gallimard, 1990.

Os pensadores originários. Anaximandro, Parmênides, Heráclito. Bragança Paulista: Editora Universitária São Francisco, 2005.

PERCIA, Marcelo. La figura de la ausencia en Thomas el Oscuro, de Maurice Blanchot. In: Instantes y azares. Escrituras Nietzscheanas, Nr. 11, 2012.

PLATE, S. Brent. Obfuscation: Maurice Blanchot"s religous re-citation of the limits. In:Literature \& Theology, Vol. 11, Nr. 3, 1997.

RAPAPORT, Herman. Heidegger \& Derrida: reflections on time and language.

Lincoln: University of Nebraska Press, 1991.

RAVEL, Emmanuelle. Maurice Blanchot et l'art au Xxème siècle - une esthétique du désoeuvrement. Amsterdam: Rodopi, 2007.

SAFRANSKY, Rüdiger. Heidegger, um mestre da Alemanha entre o bem e o mal. São Paulo: Geração Editorial, 2000.

SARTRE, Jean Paul. "Aminadab" ou du fantastique considéré comme un langage. In: Situations I.

SCHESTAG, Thomas. Mantis, Relics. In: Yale French Studies Nr. 93: The place of Maurice Blanchot.

SHEAFFER-JONES, Caroline. The point of the story: Levinas, Blanchot, and "the madness of the day. In: Modern French Studies, Vol. 54, Nr. 1, 2008. 
WAHL, François. Estruturalismo e filosofia. São Paulo: Cultrix, 1970.

WALL, Thomas Carl. Radical passivity: Levinas, Blanchot, and Agamben. Albany:

State University of New York Press, 1999.

WILHELM, Daniel. Maurice Blanchot et la voix narrative. Paris : Lignes, 2005.

WINFREE, Jason Kemp. On the lineage of oblivion: Heidegger, Blanchot, and the fragmentation of truth. In: Research in phenomenology, Nr. 25, 2005.

SARTRE, Jean Paul. L'imaginaire. Paris : Gallimard, 1940.

SCHULTE-NORDHOLT, Anne-Lise. Maurice Blanchot, l'écriture comme expérience du dehors. Genève: Droz, 1995.

ZANETTA, Julien. Lois de l'aveugle: Notes sur La Folie du Jour. In: MLN, Nr. 123, 2008. The Johns Hopkins University Press.

ZARADER, Marlène. L'être et le neutre - à partir de Maurice Blanchot. Lonrai: Éditions Verdier, 2000. 